\title{
PREDICTING INVASIVE RANGE OF Eucalyptus globulus IN
}

CALIFORNIA

\author{
A Thesis \\ presented to \\ the Faculty of California Polytechnic State University, \\ San Luis Obispo
}

\author{
In Partial Fulfillment \\ of the Requirements for the Degree \\ Master of Science in Agriculture \\ by
}

Anthony J. Lopez

December 2015 
(C) 2015

Anthony J. Lopez

ALL RIGHTS RESERVED 


\section{COMMITTEE MEMBERSHIP}

TITLE:

AUTHOR:

DATE SUBMITTED:

COMMITTEE CHAIR:

COMMITTEE MEMBER:

COMMITTEE MEMBER:
Predicting Invasive Range of Eucalyptus globulus in California

Anthony J. Lopez

December 2015

Scott Steinmaus, Ph.D.

HCS Department Head and Professor

Professor of Biological Science

David Headrick, Ph.D.

Professor of Horticulture \& Crop Science

Jenn Yost, Ph.D.

Assistant Professor of Biological Science 


\section{ABSTRACT \\ Predicting Invasive Range of Eucalyptus globulus in California \\ Anthony J. Lopez}

Eucalyptus globulus is the subject of intense debate in California. Its invasive potential, aggressive growth, reproductive biology, and association with fire make the prediction of spread important in California. Two modeling simulations, Climex and Maxent, will illustrate the distribution and potential growth range of E. globulus in California based on climate and presence. Modeling the potential range of growth will predict invasive spread. The anticipated result is the continued spread of E. globulus in coastal regions with adequate moisture and suitable climate. Predicting the range of E. globulus in California dictates management strategy and is key for preventing further introduction, establishment, and dispersal.

Keywords: Eucalyptus globulus, blue gum, invasive, epicormic, lignotuber, serotiny, allelopathy. 


\section{ACKNOWLEDGMENTS}

Thank you to my graduate committee for their guidance and continuous faith. Thanks to my parents for their patience, love, and support. Special thank you to my father for

helping with tuition. Special thanks to Dr. Matt Ritter for providing the GPS coordinates for Eucalyptus globulus trees in California. Additional special thanks to:

Becky Powell, Graduate Programs Assistant Melanie Guiterrez, College of Agriculture Graduate Program Coordinator Katherine O'Clair, Agriculture and Environmental Sciences Librarian Brenna Swanston, University Writing and Rhetoric Center tutor Adrienne King, University Writing and Rhetoric Center tutor Stacy Neely, University Writing and Rhetoric Center tutor 
TABLE OF CONTENTS

Page

LIST OF TABLES viii

LIST OF FIGURES $\quad$ ix

CHAPTER

1. INTRODUCTION 1

Background information and problem statement 1

Statement of goal to be investigated 3

Importance of the project 3

General approach $\quad 9$

2. LITERATURE REVIEW 11

$\begin{array}{ll}\text { Introduction } & 11\end{array}$

$\begin{array}{ll}\text { Exotic vs. invasive species } & 11\end{array}$

$\begin{array}{ll}\text { Exotic eucalypts in California } & 13\end{array}$

Invasive Eucalyptus globulus in California $\quad 22$

$\begin{array}{ll}\text { Geographic distribution } & 29\end{array}$

Reproduction and development 35

$\begin{array}{ll}\text { Damaging agents } & 43\end{array}$

$\begin{array}{ll}\text { Fire } & 43\end{array}$

$\begin{array}{ll}\text { Frost } & 45\end{array}$

Drought 46 
Animals

Insects and fungi

Adaptive traits

Need for risk assessment and predicting potential range of invasive plants

Conclusion

3. MATERIALS AND METHODS

Objective and hypothesis

Assumptions

4. RESULTS

Anticipated results

Model results

REFERENCES

APPENDICES

A. Specific thresholds, fractional predicted areas, and omission rates with P-values

B. Marginal response curves 


\section{LIST OF TABLES}

$\begin{array}{lll}\text { Table Page } & \end{array}$

1. Variable contribution analysis. 114

A1. Thresholds and omission rates. 144 


\section{LIST OF FIGURES}

Figure $\quad$ Page

1. Eucalypt specialists vs. North American species (Hansen, 1997). 21

2. Understory vegetation is nearly void in eucalypt groves. Montaña de Oro State Park, Los Osos, Ca. November 27, 2015.

3. Eucalyptus globulus spread into native coastal scrub at the edge of the planted grove. Montaña de Oro State Park, Los Osos, Ca. November 27, 2015.

4. Locations mentioned in the text. Figure from Kirkpatrick, 1975.

5. Mature leaves, seed capsules, and flowers of E. globulus. Montaña de Oro State Park, Los Osos, Ca. November 27, 2015.

6. Seedling recruitment as a function of dispersal and survival (Cook, 1980).

7. Exposed root systems of E. globulus. Montaña de Oro State Park, Los Osos, Ca. November 27, 2015.

8. Epicormic growth. Montaña de Oro State Park, Los Osos, Ca. November 27, 2015.

9. Exposed lignotuber (Pryor, 1976).

10. Distribution of 24 frequently cultivated pine species (abbreviated) in a space created by three biological variables separating invasive and non-invasive species (Rejmánek \& Richardson, 1996).

11. Stump sprouting. Montaña de Oro State Park, Los Osos, Ca. November $27,2015$.

12. Climex software comes with a meteorological database that represents 2031 locations around the world and 14 for California (Steinmaus, 2002c).

13. The confusion matrix is often used to test predictions against observations and is comprised of predicted versus observed presences $(+)$ and absences (-) of the four possible occurrence predictions.

14. Native distribution of Eucalyptus globulus in southeastern Australia and Tasmania (Kirkpatrick, 1975). 
15. Eucalyptus globulus distribution range by county in California. Blue indicates counties with herbarium specimen records. Purple indicates counties with reported records (Calflora, 2015).

16. Comparing locations in Climex (temperate template and Australia).

17. Climex temperate template model of Australia.

18. Climex temperate template climate parameters.

19. Parameter fitting.

20. Comparing locations (E. globulus and Australia).

21. The Climex model for the native distribution of E. globulus using the manipulated parameters.

22. Fog drip data modeled using the irrigation scenario.

23. Comparing E. globulus and California using the irrigation scenario.

24. Predicted invasive potential of E. globulus in California, modeled by Climex.

25. Climex predicts cold stress prevents E. globulus growth in northern California, and dry stress prevents growth in southern California.

26. Maxent requires presence data ("Samples" i.e. GPS coordinates), a directory containing environmental data ("layers" i.e. variables), and an output locale (“directory" i.e. results location) (Phillips, 2005).

27. The Maxent program screen after browsing and selecting the appropriate files for E. globulus localities (Samples), California environmental variables (layers), and output destination (directory).

28. Options are selected to create response curves, make pictures of predictions, and perform jackknife testing to measure variable importance. Clicking "Settings" allows "Random test percentage" parameter entry to designate (the amount of) data set aside for model validation.

29. Pressing the "Run" button initiates distribution modeling. A progress bar monitors and illustrates progression and describes the steps taken during the process. 106

30. Maxent model picture representation for Eucalyptus globulus in California.

31. Omission vs. predicted area for Eucalyptus globulus. 
33. Response curves using only the corresponding variable.

34. Jackknife test for variable importance.

35. Jackknife test using test gain. Conclusions about the most important variables can change with test data.

36. Jackknife test using AUC on test data.

B1. Response curves. These curves display the marginal effect of changing one environmental variable, keeping all other variables at average sample value. 


\section{Chapter 1}

\section{Introduction}

\section{Background information and problem statement}

Eucalyptus globulus Labill. (Myrtales: Myrtaceae) was introduced to California from Australia in 1853 (National Park Service, 2006). Extensive commercial plantations appeared after 1870, and a second planting boom occurred in the early 1900s (Boyd, 2000; Groenendaal, 1983). However, popularity declined by the 1930s due to decrease in demand and its unsuitable characteristics for lumber production (Boyd, 2000).

Today, E. globulus is the most extensively planted Eucalyptus species in the world for paper production but has been particularly successful in the Mediterranean climates of California, Portugal, Spain, Chile, and western South Africa (Skolmen, 1983; Skolmen \& Ledig, 1990). Eucalyptus globulus is the most widespread, naturalized Eucalyptus species in California and has become invasive in coastal locations (Boyd, 2000; McClintock, 1993). Large E. globulus trees were planted in small groves or windbreaks in both urban and rural areas (Boyd, 2000). However, fear over its ecological impact on native vegetation and fire potential threatens the genus today (Tyrell, 1999).

Invasive species threaten native biological diversity and many of the state's natural communities and ecosystems (Randall \& Hoshovsky, 2000). Invading E. globulus is particularly a threat to maritime chaparral, coastal scrub, and Coast Live Oak woodlands. Concentrated calcium in E. globulus leaves increases soil pH as litter decays. Soils in $E$. globulus groves contain significantly less carbon but more phosphorous and nitrogen compared to native forest types. Dense E. globulus stands form a monoculture with few plants growing understory (National Park Service, 2006). 
Invasive plants spread into national parks, preserves, and other wildlands and threaten native species and communities these sites aim to protect (Randall \& Hoshovsky, 2000). Eucalyptus globulus grows on protected land and now threatens protected areas. Acreage of E. globulus will continue to increase without management (National Park Service, 2002).

Eucalyptus globulus grows best in the California coastal fog belt and is most invasive on coastal sites exposed to summer fog drip (Boyd, 2000; Skolmen \& Ledig, 1990). Skolmen and Ledig (1990) found E. globulus is successful in only 21 inches of annual rainfall in coastal California because frequent fog compensates for rain. Eucalyptus globulus adjusts to a broader rainfall regime and grows taller outside Australia (Doughty, 2000). Eucalyptus globulus can spread from planted locations in areas with adequate moisture, so they should not be planted near rivers and streams (Boyd, 2000; Steinmaus, Rejmánek, Ritter, Jasieniuk, \& Knight, n.d.; Rejmánek \& Richardson, 2011).

Public outcry for both removal and preservation has caused controversy in California. Criticism stems from excessive water use and nearby crop suppression, possible allelopathy suppressing ground vegetation and resulting soil erosion, increased fire hazard, and poor wildlife value (Rejmánek \& Richardson, 2011). Preservation support stems from E. globulus being considered valuable for landscape, heritage trees with historical value, and habitat for displaced species (e.g. Monarchs) (Rejmánek \& Richardson, 2011; Steinmaus et al., n.d.).

Eucalyptus globulus has been a part of the California landscape since the second half of the Nineteenth Century, and many old trees are considered "heritage trees" with "historical value" (Rejmánek \& Richardson, 2011). Trees associated with military posts 
and ranches also have historic significance (National Park Service, 2002). Proponents feel eucalypts make California uniquely exotic in comparison to other parts of the United States, and removing trees therefore sparks controversy (Rejmánek \& Richardson, 2011). Removing established groves usually involves felling very tall trees in dense forests containing trees of differing ages, littered with debris, and often full of stumps (National Park Service, 2006). Trees scattered in sensitive environments and human settlements are especially difficult to remove (Steinmaus et al., n.d.). Cutting back growth from stumps or lignotubers to eventually kill trees is labor-intensive and expensive (Rejmánek \& Richardson, 2011). Stage-cutting, removing smaller trees first, opens areas for larger tree removal, but requires different equipment and experience. Freshly cut stumps are most commonly treated with herbicide (National Park Service, 2006). Biological control is an unlikely management option because of the potential harm to desirable groves (Rejmánek \& Richardson, 2011).

\section{Statement of goal to be investigated}

The overall goal of this research involves assessing the invasive potential of foreign plants in wildlands. Predicting where plant species may become invasive assists prevention strategies (Steinmaus, 2002b). Empirical models will predict the potential range and general population of invasive plants. The specific goal is predicting the invasive range of Eucalyptus globulus in California.

\section{Importance of the project}

Introduced alien species are recognized as the greatest biodiversity threat after habitat loss and are estimated to cost Americans $\$ 137$ billion every year (Pimentel, Lach, 
Zuniga, \& Morrison, 2000; Wilson, 1992). Invasive plants spread quickly and threaten native plant communities and native wildlife habitat (Randall \& Hoshovsky, 2000). Invasive plant species degrade both ecosystem productivity and biological diversity, alter ecosystem processes, and displace native species (Mullin, Anderson, DiTomaso, Eplee, \& Getsinger, 2000; Randall \& Hoshovsky, 2000). Hybridization with native species can eliminate native genotypes. Invasive plants also support exotic animals, fungi, and microbes (Randall \& Hoshovsky, 2000). Foreign, invasive plants are no longer associated with their natural predators and therefore have increased potential to thrive and escape control (California Invasive Plant Council, 2015b).

The National Invasive Species Council (2001) estimated 100 million infested acres in the United States. Economic impacts of introduced weed species on the United States economy were estimated to equal or exceed $\$ 13$ billion per year in 1994 (Westbrooks, 1998). Wilcove, Rothstein, Dubow, Phillips, \& Losos (1998) found 57\% of endangered plants in the United States are threatened by alien species. Davies and Sheley (2007) estimated invasive species contributed to $35-46 \%$ of the plants and animals placed on the United States Federal Endangered Species List. Furthermore, the negative impacts of invasion escalate with increasing infestation (Davies \& Sheley, 2007; Westbrooks, 1998).

Invasive plants pose complex problems with long-lasting effects and spread and invade new areas even when no longer introduced (Randall \& Hoshovsky, 2000). Introduction and distribution consequences require assessment and implementation policies and practices to lower introduction risk (White, 1997). Effective control requires long term commitments and must include a coordinated effort from federal, state, institutional, and private sector levels (Mullin et al., 2000). 
California has severe, extensive invasive plant problems. Variation in topography, geology, and climate helped create California's extraordinary native biological diversity. However, exotic plant species also find conditions suitable for establishment, and many non-natives have rapidly spread (Randall \& Hoshovsky, 2000). In fact, 4200 native plant species grow in California, and approximately 1,800 non-natives also grow in the wild (California Invasive Plant Council, 2000). Less than 10\% of non-native plant species established in California are recognized as serious invasive threats, but these plants have dramatically changed the ecological landscape and inhabit a much greater proportion of landscape (California Invasive Plant Council, 2000; Randall \& Hoshovsky, 2000; Randall, Rejmánek \& Hunter, 1998). The worst invasive plants alter ecosystem nutrient cycles, hydrology, sediment deposition, erosion, and fire frequency and intensity (D'Antonio \& Vitousek, 1992; Vitousek, 1986; Vitousek \& Walker, 1989; Vitousek, Walker, Whiteaker, Mueller-Dumbois, \& Matson, 1987; Whisenant, 1990). Invasive plants reduce or eliminate protected species in national parks, preserves, and other wildlands (Randall \& Hoshovsky, 2000).

Eucalyptus globulus is the most widespread Eucalyptus species in California (National Park Service, 2006). According to the United States Department of Agriculture (USDA) Forest Service, California plantings total 40,000 acres (as cited in Skolmen \& Ledig, 1990). Cultivation began in the 1850s as an ornamental landscaping tree and continued soon after for timber production (National Park Service, 2006). Eucalyptus globulus was chosen and planted commercially mainly due to its rapid growth characteristics (National Park Service, 2006). Occurrence in California is due more to intentional planting than naturalization (Ritter \& Yost, 2009). 
Eucalyptus globulus thrives on the California coast (National Park Service, 2006). Conditions are most favorable for growth and regeneration along northern and central California coasts (Ritter \& Yost, 2012). Yost notes its regeneration capacity is environmentally based and areas with reliable moisture are most likely to support naturally reproducing populations (as cited in California Invasive Plant Council, 2015a). Spreading populations on the western United States coast may indicate the start of significant invasive spread after a long lag phase (Steinmaus et al., n.d.). Often, a time lag exists between a plant's first introduction and its rapid spread. Species rarely problematic today may turn out troublesome decades from now. Therefore, determining its range of spread is urgent while populations are small (Randall \& Hoshovsky, 2000).

Socio-political controversy surrounds E. globulus in California. Eucalypts attract the most criticism of common plantation species (Rejmánek \& Richardson, 2011). The common charges are fire hazard increase, excessive water use and/or streamflow or water table reduction, vegetation and crop suppression (allelopathy), soil degradation (from excessive nutrient depletion, allelopathy, and resulting erosion), and poor wildlife value (Rejmánek \& Richardson, 2011; Florence, 1996). Public outcry for removal has erupted in many locations to prevent fire and invasive expansion (Steinmaus et al., n.d.). Urban population management involves considering factors including recreation and aesthetic value in the wildfire debate (California Invasive Plant Council, 2015a).

Eucalyptus globulus' reputation in California has people choosing sides. Naturalists dislike the tree because it is an aggressive, highly flammable, exotic (California Agriculture, 1996). Large trees in urban settings are also hazardous because of potential branch failure (Boyd, 2000). Others appreciate its aesthetic landscape and highway 
barrier value, windbreak and shade source use, or value it for fuelwood production (Rejmánek \& Richardson, 2011; Santos, 1997; Skolmen \& Ledig, 1990).

Some trees are associated with bay area military posts and ranches established in the late 1800s and early 1900s, and their historical significance especially concerns cultural resource managers. For example, E. globulus trees make up nearly half of the historic 400-acre Presidio forest. However, historic landscapes can overgrow, biological diversity can decline, and the potential for catastrophic wildfire can increase without active management (National Park Service, 2006).

Spreading E. globulus populations have been identified along the western United States coast (California Invasive Plant Council, 2015a; Steinmaus et al., n.d.). The importance of predicting the potential range and impact of E. globulus in California is imperative for risk assessment and invasion prevention. Prevention is the most cost effective management strategy for invasive species (Steinmaus, 2002c). Climatic suitability and potential successful invasive spread must be assessed for management. Prediction anticipates invasive potential and areas most susceptible to invasion (Steinmaus, 2001). It also helps understand disturbances facilitating invasion, and where to concentrate education, research, and prevention efforts under current and future climate scenarios (Steinmaus, 2001; Steinmaus, 2002b; Steinmaus, 2002c; Steinmaus et al., n.d.). Future California climate scenarios predict higher precipitation in areas where moisture limitations currently exclude E. globulus (Steinmaus et al., n.d.). Prevention and management of invasive plants preserves viable populations of many native species and natural communities and ecosystems (Randall \& Hoshovsky, 2000).

Eucalyptus globulus' highly flammable litter, loose bark, brittle branches, and 
frequent presence in urban areas creates a unique, realized danger for California (Steinmaus et al., n.d.). The 1991 East Bay Hills Fire, known as the worst wildfire in California history, caused $\$ 1.5$ billion in damage and killed 25 people (National Park Service, 2006). Dense, frost damaged E. globulus trees were identified as major contributors to the fire's behavior and intensity (National Park Service, 2002; Rejmánek \& Richardson, 2011). Impact is exacerbated by hillside runoff, soil erosion, and debris flow after fire (Cannon et al., 2007; Sheridan, Lane \& Noske, 2007).

Ecosystem disturbances, including wildfire outbreaks, are increasing in North America, and fire risk in the western United States will likely intensify with warmer temperatures, drier soils, and longer growing seasons (Field et al., 2007). North American forest fire seasons will likely lengthen and high danger areas will likely increase significantly (Cohen et al., 2001). Increase in ecosystem disturbances accelerates loss of native species and facilitates (prepares the site for colonization) invasive species (Sala et al., 2000). Changes in wildfire frequency caused by human activities may also hinder native plant survival and promote exotic plant invasion (Randall \& Hoshovsky, 2000). Invasive species, preadapted to the new conditions, will likely become even more important (Steinmaus et al., n.d.).

Eucalyptus globulus demonstrates limited overall invasive potential in California, but populations are spreading from original plantings along the California coast (California Invasive Plant Council, 2015a; Steinmaus et al., n.d.). Native plant communities and corresponding wildlife habitat are displaced in E. globulus groves, so identifying invading populations is crucial while populations are still small (Boyd, 2000; Randall \& Hoshovsky, 2000). Eucalypt seeds have no dormancy, so local eradication is 
achievable (Rejmánek \& Richardson, 2011). Thus, predicting the potential range of $E$. globulus in California is urgent while populations are still manageable.

Eucalyptus globulus removal is difficult and expensive, especially where scattered trees grow in sensitive habitat and urban areas (Boyd, 2000; Steinmaus et al., n.d.). Removal has become significantly controversial (Coates, 2007). Furthermore, $E$. globulus vegetatively regenerates from lignotubers after disturbance, and desirable trees would potentially be destroyed by biological control (Steinmaus et al., n.d.). Eradication strategies involve falling tall, dense trees and managing or removing persistent stumps (National Park Service, 2006). Removal of eucalypts also potentially creates opportunity for alternate invasive species establishment (California Agriculture, 1996).

Prevention is the most cost effective management strategy for invasive plants in managed ecosystems (Steinmaus, 2002c; Steinmaus et al., n.d.). Risk assessment is the first step for prevention strategies (Rejmánek, 2001). Predicting where plant species might be problematic is a key prevention program component (Steinmaus, 2002b). Predicting potential range of E. globulus in California may remedy vulnerabilities before invasion. Determining the potential range of E. globulus in California will provide focus for education and management efforts (Steinmaus, 2001).

\section{General approach}

This predictive study focuses on the invasive range of E. globulus in California. Modeling forecasts and predicts the potential range and general population of E. globulus in California. I used two computer simulation programs, Climex and Maxent, to construct models illustrating and predicting potential range of E. globulus in California. Climex uses biological information to determine overall climatic suitability for a species 
at a location. Maxent uses geographic coordinates and environmental variables to map geographic distribution. 


\section{Chapter 2}

\section{Literature Review}

\section{Introduction}

Eucalyptus globulus is controversial in California. Public support for both removal and preservation of E. globulus is significant. However, its invasive potential is unknown (Steinmaus, 2007). Conclusions about the impacts of eucalypts are often anecdotal and context-dependent (Rejmánek \& Richardson, 2011). Here, I will cover exotic vs. invasive species, exotic eucalypts in California, invasive Eucalyptus globulus in California, geographic distribution, reproduction and growth, damaging agents, adaptive traits, and the need for predicting the range of invasive plants.

Eucalyptus globulus is commonly known as Tasmanian Blue Gum and Blue Gum Eucalyptus. However, vernacular names vary by area, and the same common names are used for different species in different areas (Penfold \& Willis, 1961). Since the designation "Blue Gum" is applied to several species including E. globulus, I use the scientific name to avoid confusion. Additionally, Eucalyptus technically refers to the entire genus of $1800+$ diverse species of flowering trees and shrubs. The common descriptive term for grouping seven similar Australasian genera is "eucalypts" or "the eucalypt group" (Ladiges, Udovicic, \& Nelson, 2003; J. Yost, personal communication, October 16, 2015).

\section{Exotic vs. invasive species}

Exotic species are introduced from other parts of the globe intentionally or inadvertently. Foreign plant species introductions to new areas can cause significant 
problems. Escape into natural systems, although also often accidental, is careless (Cairns \& Bidwell, 1996). Intentional introductions are also careless because they happen without foresight or regard for potential problems. Exotic species introduction policy relies on invasivity prediction and risk assessment (White, 1997). Exotic species become "invasive" when they spread and displace native flora and corresponding fauna (California Invasive Plant Council, 2015b; Rejmánek, 1995). Because they evolved in other areas, invasive plants lack natural predators for management. Invasive plants can spread quickly, displace native vegetation, and alter ecosystem hydrology, fire regimes, and soil chemistry (California Invasive Plant Council, 2015b).

Additionally, invasion disrupts natural ecosystems ecologically, and the worst ones transform landscapes by changing the character, condition, form, and nature of the invaded area. Invasive plants can transform landscapes by excessively using resources. Invaders have increased light capturing, water or nutrient consuming, or gas depleting ability. Landscape transformations reduce the adaptability and competitiveness of desired native species (Bell, DiTomaso, \& Wilen, 2007). Natural areas are also indirectly threatened by invasive plants because management strategies include herbicide use, habitat manipulation, and biocontrol agent introduction (White \& Schwartz, 1998). Invasive plants can blanket waterways, trails, and scenic landscapes. Therefore, invasive plants can make boating, hiking, biking, and other outdoor recreational activities difficult and lower the land's property, photography, and wildlife viewing value. Invasive plants can also displace crops and rangeland forage and consume enormous water quantities. Management is important and often necessary because invasive plants can be fire 
hazards, low in nutrition, and even poisonous to livestock (California Invasive Plant Council, 2015b).

Invasive plants can also significantly degrade wildlife habitat. Hence, invasive plants can reduce game species' habitat and hunting and fishing resources. Invasive aquatic plants form dense mats and restrict boat access and also kill fish by reducing water oxygen content. Dense monocultures of invasive plants inhibit native plant species growth and results in loss of native wildlife food and shelter sources (California Invasive Plant Council, 2015b).

\section{Exotic eucalypts in California}

Californians became interested in eucalypts during the Gold Rush (Doughty, 2000). The population influx in the Bay Area and valley created demand for timber and timber products (Groenendaal, 1983). The Australian trees pleased citizens concerned about deforestation and replanting in the Bay Area. Eucalypts also met growing demand for plants as novelties and profitable business ventures (Doughty, 2000).

The first eucalypts were cultivated in California around 1850. Influential, wealthy citizens promoted its introduction for industrial, agricultural, ornamental, and health benefits. Promoters pushed eucalypts as an asset for California and the whole nation (Doughty, 2000). These fast-growing, giant trees could be exploited for financial gain and interested enterprising men (Purdy, 1968). The excitement and surge of interest led to a planting boom in the early 1900s (Santos, 1997).

Eucalypt perception preceding and during the 1920s also focused on renovation. Restoration of native vegetation was rarely demanded by critics (Tyrell, 1999). "Californians still preferred their garden ideal of an 'improved' landscape of forests, 
farms, trees, and gardens to the authentic beauty of the (still imagined) natural environment" (Tyrell, 1999).

Ornamental and economic rationales were reinforced by health claims. Eucalypts became known as "Australian fever trees" and were expected to contribute to the health and wealth of Californians. Health claims about supposed disinfectant properties in malaria control justified extensive planting. Nineteenth-century medical theory claimed many infectious diseases, including malaria and cholera, were transmitted through the air. Health authorities focused on improving the flow of waterways and used eucalypts to drain swamps because stagnant water and polluted soil were regarded as sources of these vapors. Claims that aromatic oils secreted from eucalypt leaves combined with moisture and air, released hydrogen peroxide, and disinfected air were widely publicized by the California press (Tyrell, 1999).

Trading between mainland Australia, Tasmania, and New Zealand increased during the 1830s, and Tasmanian trading ports in Hobart Town and Launceston grew in importance (Lawson \& The Shiplovers Society of Tasmania, 1949). Seventeen ships left Hobart and Launceston for California in 1849 carrying at least 500 travelers, and all available ships were on the San Francisco berth in 1850 (Lawson \& The Shiplovers Society of Tasmania, 1949; Monaghan, 1966). Tasmanians were known for building sound, fast, full-rigged ships rivaling any in the world, and their ships made from Eucalyptus globulus sailed into San Francisco Bay (Lawson \& The Shiplovers Society of Tasmania, 1949). These ships were representatives of Tasmania's giant eucalypts and garnered instant attention and fame (Monaghan, 1966; Santos, 1997).

Many prospectors were previously farmers, and they returned to agriculture after 
leaving the gold fields. They farmed looking for easy fortune, and widespread planting was based on the tree's reputation for successful acclimation, rapid growth, requiring no care after planting, fuel, timber, and medicine. Momentum behind widespread planting stemmed from the belief that Californian eucalypts were the fastest growing trees in the world and timber would retain the same qualities as Australian grown eucalypts. Farmers capitalizing on the evolving fuel crisis realized trees coppiced well and regenerated quickly. Rapid regeneration made eucalypt farming appealing to farmers used to harvesting crops every year. Desire to profit from the land, utilize marginal land, and obtain an inexpensive fencing material motivated eucalypt planting in California (Purdy, 1968).

Local, state, and federal governments all became interested in tree cultivation (Purdy, 1968). California state law prohibited cutting trees on private land or public streets in 1862. The California Tree Culture Act of 1868 encouraged tree plantings along roads, and county supervisors coordinated efforts to pay growers $\$ 1$ per planted tree after four years (Santos, 1997). Deforestation and predictions of national timber famine also inspired the federal Timber Culture Act of 1873 and required homesteaders to plant 40 acres (later reduce to 10) of trees for every 160 acre claim (Doughty, 2000). Large scale eucalypt, mostly E. globulus, plantations arose in California (Penfold \& Willis, 1961). The eucalypt industry in California expanded, and eucalypts could be seen anywhere in California where climate permitted by the end of the Nineteenth Century. Many of the eucalypts seen today in California are the result of the "Eucalyptus Boom" of 1905-1912 (Santos, 1997).

Commercial plantings appeared throughout the state. Santa Fe Railroad planted a 
giant grove in Rancho Santa Fe and thousands along right-of-ways to supply railroad ties where needed. The Pullman Palace Car Company planted trees with plans to finish railroad car interiors with eucalypt wood (Warren, 1962). Railroad expansion was a common source of demand for wood and was also commonly cited as a cause of the approaching timber famine (Tyrell, 1999). A mining company planted a grove in Compton, expecting timber for mine shafts. Furniture companies purchased land and planted trees heavily (Warren, 1962). Jack London believed eucalypt wood was ideal for replacing the Oakland and San Francisco wharf pilings and planted 100,000 seedlings on Sonoma Mountain (Jack London State Historic Park, 2015). 40 square miles were planted south of Pismo Beach, in San Luis Obispo County. Eucalypts promised more profit than grain, so thousands of acres of prime agricultural land were also planted with trees (Warren, 1962).

Early eucalypt farmers in California encountered problems with cultivation from the very beginning. Farmers discovered cold winter weather killed young trees and caused larger trees to drop branches (Pacific Rural Press, 1879). Prolonged periods of freezing nightly temperatures during the winter of 1880-81 fatally burned entire E. globulus plantations all over the California coast (Pacific Rural Press, 1881). Californian farmers also realized strong winds leveled cultivated stock (Purdy, 1968). The Pacific Rural Press $(1877 ; 1883)$ printed reports about eucalypt roots destroying adjacent trees and crops and drying up water wells. The decline of the firewood market also severely setback eucalypt cultivation. Eucalypts became known as “Australian Weeds" in 188384 (Purdy, 1968). Farmers were warning against using eucalypts as windbreaks by 1888 
(Pacific Rural Press, 1888). California cities began cutting down eucalypts (Purdy, 1968).

The Eucalyptus boom slowed further with discovery Californian eucalypt wood warped, cracked, twisted, and became tough once cured. The Santa Fe Railroad discovered the timber was not suitable for ties, poles, and railcar interiors (Warren, 1962; Santos, 1997). Telegraph poles made from eucalypts held up wire well but rotted quickly and were destroyed by beetle larvae (Purdy, 1968). Lumber from young trees grown in California did not compare to eucalypt timber from much older trees in Australia (Betts \& Smith, 1910). A 1910 report from the State Board of Forestry showed eucalypt growth rates did not meet expectations (Margolin, 1910). Projected yields took too many years to realize. United States timber consumption declined after 1910, and steel, cement, and other substitutes filled the hardwood shortage void (Santos, 1997; Tyrell, 1999). Metal automobiles replaced wooden wagons and carriages. Oil, gas, and electricity took precedence over using eucalypts for fuel (Santos, 1997). Eucalypts also suffered popularity decline because they did not reproduce well in California without human intervention (Tyrell, 1999).

Eucalypt speculation and interest waned during the end of the Nineteenth Century and early 1900s (Purdy, 1968). Then, the California Water and Forest Association published a report about diminishing national timber resources and the need to ensure future supply entitled The Timber Supply of the United States in the July 1907 issue of Water and Forest magazine. The preceding page contained a section entitled Eucalyptus by the California Fruit Grower. The section mentions timber of great enduring qualities, rapid growth, drought tolerance, valuable oil, fuel value, ornamental qualities, and 
windbreak value. The California Fruit Grower ends the section claiming eucalypts are probably the most valuable trees for arid parts of the west. The USDA Forest Service published Circular 116: The Waning Hardwood Supply and the Appalachian Forests by assistant forester William Hall in September 1907 and contributed to the national timber crisis fear.

Eucalypt planting became extensive again in California, and the state board of forestry issued Circular No. 2: A Handbook for Eucalyptus Planters in cooperation with the USDA Forest Service in 1908. The University of California Agricultural Experiment Station in Berkeley printed Eucalyptus in California Bulletin No. 196 by Norman Ingham the same year. Companies formed to grow eucalypts commercially, and the California State Forester reported 23,000 acres planted in California during fall 1909 and spring 1910 (California State Board of Forestry, 1910).

Conservation became increasingly focal, and the "timber famine" rationale caused President Roosevelt to transfer millions of acres of government land to the Department of Agriculture and establish the United States Forest Service (Maccleery, 2008; Williams, 2005). However, conservation policies suppressed fire for decades, favored fast growing species, and increased fuel loads and tree density. California chaparral and forests are naturally fire prone under native conditions, and ground fires were now given a direct route to tree crowns. No-burn policy provided ground fires with a ladder to the canopies of mature, old growth trees. Reduced logging also accelerated fuel load accumulation. Frequent, low temperature ground fires every few years under native conditions turned to intense, catastrophic conflagrations (Steinmaus, 2002a).

Eucalypts have displaced some native tree species in California (Steinmaus et al., 
n.d.). Although E. globulus was typically planted on grasslands, oak or bay laurel woodland is their most native analog habitat in California (California Invasive Plant Council, 2015a). The National Park Service (2002) identifies Coast Live Oak and California $\underline{B}$ ay tree communities as especially threatened by invading eucalypts. McBride, Sugihara, and Amme (1988) found native tree species growing only in low density E. globulus groves. On the central California coast, E. globulus is spreading into the coastal sage scrub and chaparral habitat of Morro manzanita (Steinmaus et al., n.d.). Morro manzanita, Arctostaphylos morroensis Wies. \& Schreib. (Ericales: Ericaceae), is an endangered shrub native to San Luis Obispo County that is only found near Morro Bay, Ca (Rogers, 2015). Equal outcry has emerged to preserve eucalypt groves for displaced species habitat. The Monarch butterfly, Danaus plexippus L. (Lepidoptera: Nymphalidae), has taken refuge in these transformed habitats (Steinmaus et al., n.d.). Monarch butterflies use eucalypts for overwintering in California every fall. Eucalypts provide major shelter and nectar for migrating Monarch butterflies during winter months (Rejmánek \& Richardson, 2011). However, Monarchs also find overwintering shelter in native Coast Redwood Sequoia sempervirens (Pinales: Cupressaceae), Monterey Pine Pinus radiata (Pinales: Pinaceae), and Monterey Cypress Cupressus macrocarpa (Pinales: Cupressaceae) (Griffiths \& Villablanca, 2015).

Their migration from throughout North America to California and central Mexico is unique among insects. The North American Monarch butterfly is the only insect in the world making an annual, routine, long-distance migration. Most Monarchs in western states overwinter on the California coast every year and often use the same trees. These relatively mild areas provide specific protective microclimates with stable temperature, 
sunlight, calm, and humidity for overwintering. Most overwintering sites are endangered by modern activity, and Monarchs were declared internationally threatened in 1983. Scientists advise protecting all Monarch groves and buffer zones because only well protected sites with specific trees and vegetation near water have necessary characteristics (National Park Service, 2006). The United States Fish and Wildlife Service is reviewing a petition for federal protection under the Endangered Species Act, but The Monarch butterfly is not currently protected by domestic law (The Center for Biological Diversity, The Center for Food Safety, The Xerces Society, \& Brower, 2014; United States Fish and Wildlife Service, 2015b).

Birds are at the forefront of the debate about eucalypts' effects on native ecosystems. Although many bird species nest, roost, and forage in eucalypts, native birds prefer native woodland over E. globulus stands (Keane \& Morrison, 1990; National Park Service, 2006). Diversity of arthropods, small mammals, and birds is usually significantly lower in eucalypt stands compared with native vegetation (Rejmánek \& Richardson, 2011). However, Sax (2002) found near identical species richness and diversity for understory plants, invertebrates, amphibians, and birds in eucalypt groves compared with native California woodlands (oak and bay trees). Eucalypts often provide essential resources and habitat for birds in urban agricultural settings, but eucalypt stands are an inequivalent trade for the native oak woodland and deciduous riparian habitat they replace (Suddjian, 2004).

Flowering eucalypts attracts insects and invites migratory birds. Australian honeyeaters and leaf gleaners evolved long, curved bills for probing flowers and avoiding the sticky gum resin (Figure 1). Kinglets, vireos, and wood warblers are all North 


\section{Eucalyptus specialists "down under" are larger and better}

equipped than North American species to forage flowering trees.
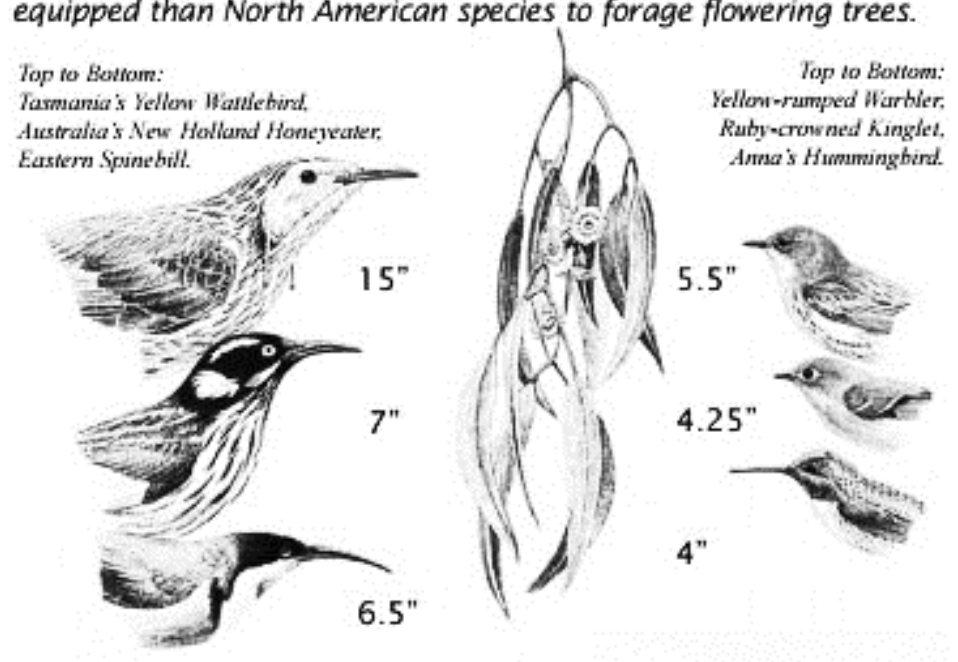

Figure 1. Eucalypt specialists vs. North American species (Hansen, 1997).

American leaf gleaners with short, straight bills. Their short bills must probe deeply into flowers for insects or nectar (Stallcup, 1997).

Birds use suitable tree hollows and branches (dead wood and cavity nesters), foliage (above ground foliage nesters), and ground vegetation (ground nesters) for nesting and shelter (Recher, 1991). Many bird species representative of native oak and riparian habitat hardly utilize eucalypt trees. Many bird species that do nest in eucalypts do so in lower densities than native habitat (Suddjian, 2004). The Point Reyes Bird Observatory (PRBO) found nesting birds have greater nest survivorship in native vegetation (National Park Service, 2006). Eucalypts give nesting birds false security (Williams, 2002). The PRBO exposed crashing bird populations from nesting in eucalypts every year and producing nearly no young (Williams, 2002). Great Horned Owls, Red-shouldered Hawks, Common Ravens, and American Crows successfully nest in eucalypts, but they prey on smaller birds or nests (National Park Service, 2006). Ground foraging, 
insectivorous birds can also be put at risk by abundant eucalypt litter and woody debris (Reid, 1999). Woodpeckers and other birds that excavate nesting holes have limited opportunities in its decay resistant wood and are poorly represented in eucalypt stands (Suddjian, 2004).

\section{Invasive Eucalyptus globulus in California}

Eucalyptus globulus changes native California ecosystem processes. Biological diversity is reduced when native plants and wildlife habitat are displaced (Boyd, 2000). Eucalyptus globulus stands typically form dense monocultures and provide generally poor wildlife value (National Park Service, 2002; Rejmánek \& Richardson, 2011). Native plant communities can be severely altered where E. globulus grows in high densities and conditions are favorable (California Invasive Plant Council, 2015a). Eucalyptus globulus transforms native California environments by causing dramatic ecological change and impacting both flora and fauna. Eucalyptus globulus, therefore, facilitates its own success at the expense of native plants and reduces desirable plant diversity (Bell et al., 2007).

Accumulated litter makes unmanaged eucalypt stands extremely flammable (Rejmánek \& Richardson, 2011). Generally, fuel loads, and therefore fire intensity, increase with rainfall increase, but fire frequency increases with rainfall decrease (Ashton, 1981). Branch, bark, and leaf litter can be 4 feet thick in California because the microbes and insects associated with it are in Australia.

Leaf litter also reduces both germination and emergence (Stoneman, 1994). This may happen because of allelopathy, but accumulated litter retards native species regeneration if allelopathic chemical inhibition does not (Stoneman, 1994; Rejmánek \& Richardson, 
2011). Growth and development of understory vegetation is also inhibited by the physical barrier of accumulated litter (Figure 2) (Boyd, 2000). Accumulated, undecomposed litter forms a mat of dead plant material and inhibits desirable species establishment (Bell et al., 2007). Heavily thatched ecosystems also favor grass morphology (selection) because broadleaves cannot penetrate the dense cover while grass blades can poke through (Steinmaus, 2002f).

Understory plant establishment is also inhibited by allelopathic effects of E. globulus (Boyd, 2000). Allelopathy is the chemical suppression (germination or growth) of one plant species (or organism) by another (University of California Statewide Integrated Pest Management Program, 2014b). Oxford Dictionaries defines allelochemicals as biochemicals that detrimentally influence the growth, survival, and reproduction of other organisms (2015). Rejmánek and Richardson (2011) admitted most allelopathic reports are mostly based on bioassays, but Stoneman (1994) cited May and Ash (1990) mimicking natural conditions more closely than previous studies. May and Ash (1990) concluded eucalypts cause understory allelopathic suppression.

Toxic chemical accumulation in surface soil is encouraged by repeated fog drip, and herbaceous annual plants are missing in most mature, undisturbed E. globulus groves (del Moral \& Muller, 1969; del Moral \& Muller, 1970). The stature of E. globulus combined with its leaf shape and structure make it an efficient fog drift interceptor. Frequent overnight and early morning coastal fog often causes a heavy causes a heavy drip rain under trees (del Moral \& Muller, 1969). The condensed fog drip is most evident under trees exposed to Pacific Ocean wind (Oberlander, 1956). Frequent fog compensating for 


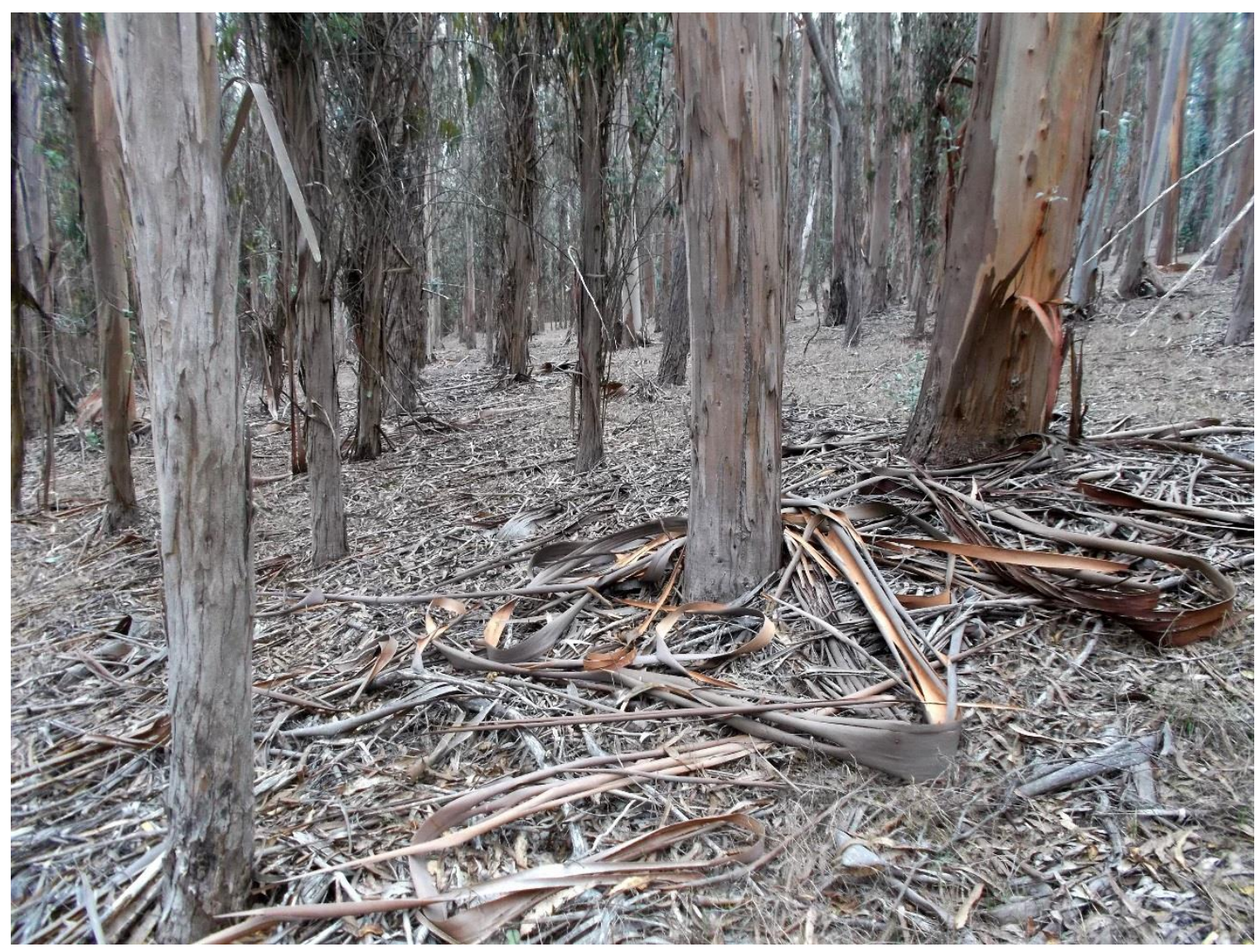

Figure 2. Understory vegetation is nearly void in eucalypt groves. Montaña de Oro State Park, Los Osos, Ca. November 27, 2015.

dry conditions is a major reason E. globulus is considered invasive in coastal locations receiving summer fog (Boyd, 2000; Skolmen \& Ledig, 1990).

The California Invasive Plant Council (Cal-IPC) had previously classified E. globulus as a moderately successful invader in 2006 (California Invasive Plant Council, 2015a). The council advises against planting E. globulus in California, based on severity of impact, ability to spread, and extent. Cal-IPC developed the "Don't Plant a Pest" program to help gardeners and landscapers select alternative non-invasive plants. The program warns E. globulus is extremely flammable, invades native plant communities, 
and negatively affects both native plant and animal populations (California Invasive Plant Council, 2015b).

However, Cal-IPC reassessed E. globulus in 2014 and changed the overall classification score from "Moderate" to "Limited." The ratings are the result of expert reviewed assessments and are designed to inform land mangers about potential impacts. The ratings are general and informative, not site-specific or prescriptive. The evaluation is now more state oriented, focusing less on coastal areas where E. globulus is most prone to spread. The council found regenerating, expanding populations in favorable conditions but also populations that are not in less favorable conditions. Some populations exist on areas being managed primarily for ecological value (e.g. native wildlife habitat) while others do not. Populations that are not regenerating and expanding are not considered invasive. Species rated "Limited" are invasive but have minor statewide impact. They can be locally persistent and problematic although their range and distribution are generally limited. Eucalyptus globulus' limited rating also indicates its reproductive biology and attributes are conducive to moderate to high dispersal rates but establishment is dependent on ecological disturbance. (California Invasive Plant Council, 2015a).

The Cal-IPC assessment uses individual criteria divided into 3 sections evaluating ecological impact, invasive potential, and ecological distribution. Each criterion is assigned a score of A (severe) to D (no impact), with U indicating unknown. Individual criteria are averaged into section scores that produce an overall rating. In 2006, Cal IPC assigned E. globulus moderate scores in all three sections and an overall moderate invader rating. The reassessment revised some criteria scores, changed the invasive 
potential score from moderate to low, and resulted in a change of the overall score from moderate to limited. Cal IPC recommends the assessment be the basis for prioritizing $E$. globulus removal in natural reserves (except Monarch butterfly groves). (California Invasive Plant Council, 2015a).

Cal IPC's overall rating indicates the ecological amplitude and distribution capacity of E. globulus is limited. The limited overall rating is primarily because of its low invasive potential, rate of spread without management, and innate reproductive potential. New populations are rare and sapling growth (spread) is typically limited to edges of existing populations (Figure 3) (California Invasive Plant Council, 2015a; Rejmánek \& Richardson, 2011). Germination is difficult in dense forests, more successful on open land, and best on bare, litter free, wet soil (Bean \& Russo, 1986; Rejmánek \& Richardson, 2011). Eucalypts bear abundant seed but generally do not reproduce well without human intervention (Tyrell, 1999). Rejmánek and Richardson (2011) listed its relative limited seed dispersal, high seedling mortality, and lack of compatible ectomycorrhizal fungi as the three main reasons behind the limited overall invasiveness of eucalypts.

However, Cal IPC notes E. globulus is still considered invasive and may be persistent and problematic locally (California Invasive Plant Council, 2015a). Most naturalized E. globulus stands exist in coastal northern and central California, and stands in moist coastal habitat often expand significantly (California Invasive Plant Council, 2015a; Ritter \& Yost, 2012). For example, E. globulus plantings on Angel Island expanded 360\% over a century (McBride, Sugihara, \& Amme, 1988).

Despite purposeful cultivation, widely planted distribution range, large quantity seed 


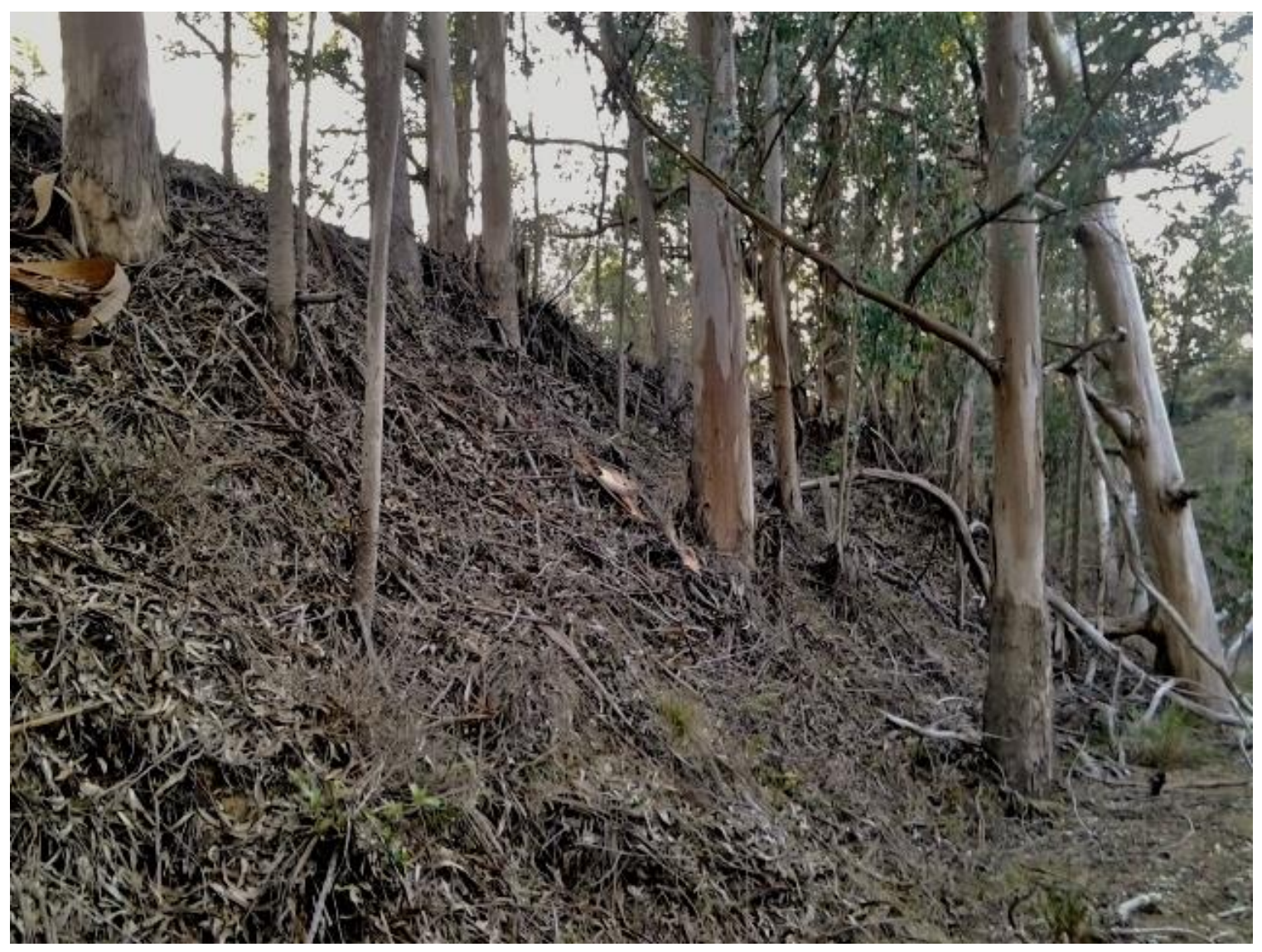

Figure 3. Eucalyptus globulus spread into native coastal scrub at the edge of the planted grove. Montaña de Oro State Park, Los Osos, Ca. November 27, 2015.

production, and diverse disturbance adaptations, the overall invasion success of $E$.

globulus is mediocre at best (Rejmánek \& Richardson, 2011). Eucalyptus globulus

requires moisture and ecological disturbance for establishment. The identified spreading

coastal E. globulus populations may signal the start of significant invasive spread

(Steimaus et al., n.d.). Future climate scenarios predict precipitation rates high enough to

support a grassland or woodland ecosystem in south eastern regions of the California

Mojave Desert (National Assessment Synthesis Team, 2001).

California annual average precipitation is projected to increase during the Twenty

First Century. This precipitation increase is a result of projected significant global 
warming and increased sea surface temperatures off the North American coast. The storm generating Pacific Aleutian Low is forecasted to shift southward, allowing more precipitation to reach the California coast. Additionally, the Pacific Subtropical High is predicted to weaken, reducing deep, cold water that rises toward the surface (upwelling) and enabling additional storm penetration into the Southwest. Pacific Ocean warming, southward movement of the Aleutian Low storm center, and the weakening of the Pacific Subtropical High together are projected to increase precipitation on the West Coast (National Assessment Synthesis Team, 2001).

Soil moisture depends on precipitation, evaporation, run-off, and soil drainage. Precipitation increase alone tends to increase soil moisture, but higher air temperatures and resulting increased evaporation rates may remove soil moisture faster than supplied. However, increases in soil moisture are projected for California. Drought is predicted to increase nationally, but California projections indicate reduced drought tendency. Soil moisture and drought tendency differences are likely the most critical for water supply, agriculture, forests, and lake levels (National Assessment Synthesis Team, 2001).

The predicted increased precipitation and soil moisture in California may provide $E$. globulus with the water necessary for establishment and landscape it prefers for successful invasion. The intensification of the hydrologic cycle will also increase humidity (National Assessment Synthesis Team, 2001). Increased humidity will further facilitate invasive spread because E. globulus is most problematic in California on coastal sites exposed to fog drip (Boyd, 2000; Skolmen \& Ledig, 1990). This hydrological modification may trigger significant invasive spread in California.

Eucalypt growth rates are often much faster in exotic locations and usually much 
faster than local indigenous species (Davidson, 1996). Davidson (1996) found eucalypts are successful on poor soils without fertilizer and achieve high biomass production on low nutrient uptake. Eucalypts take up nutrients when available, conserve nutrients within the biomass, and make highly effective use of limited nutrient pools through efficient internal cycling (Florence, 1996). Additionally, eucalypts commonly perform better than natives on recently degraded sites because few native tree species can adjust to soil acidity and low fertility correlated with degradation (Eldridge, Davidson, Harwood \& van Wyk, 1993). Therefore, eucalypts are grown on degraded soils and abandoned agricultural land unsuitable for native trees in many tropical countries. Fuel and other products from eucalypts reduce human pressure on natural forest remnants (Rejmánek \& Richardson, 2011). Eucalypts are capable of growth and life cycle completion in low fertility conditions but respond to additional nutrients with vigorous growth (Pryor, 1976).

Eucalypts planted outside Australia in regions without defoliating insects grow at remarkable rates (Food and Agriculture Organization of the United Nations, 1979). The fast growth of exotic eucalypts is partly because of freedom from indigenous Australian pests, but eucalypts also evolved on nutrient deficient soils in Australia, and fertility levels are higher in many areas growing eucalypts outside Australia (Pryor, 1976). Superior growth on exotic plantations compared to native forests can also be attributed to more rainfall, seedling spacing, site preparation, weed management, and fire management (Eldridge et al., 1993).

\section{Geographic distribution}

Eucalyptus globulus naturally occurs in Tasmania, Victoria, and New South Wales 
(Kirkpatrick, 1975; Turnbull \& Pryor, 1978). More specifically, E. globulus most commonly occurs in eastern Tasmania, the Furneaux Group, the Otway Ranges, South Gippsland, East Gippsland, south coastal New South Wales, and the foothills of the Great Dividing Range between Seymour and Burrinjuck, Australia (Figure 4) (Kirkpatrick, 1975). Eucalyptus globulus is found in areas with an annual precipitation of $60-110 \mathrm{~cm}$ and does not naturally occur in areas with less than $50 \mathrm{~cm}$ annual rainfall. Its altitudinal range is from near sea level to the maximum altitude of $1100 \mathrm{~m}$, but E. globulus is most common below $300 \mathrm{~m}$ in Tasmania, southern Victoria, and East Gippsland (Kirkpatrick, 1975). Although E. globulus prefers Mediterranean type climate, it has also grown successfully in high tropical altitudes. Eucalyptus globulus plantings have failed in temperate zones with severe winter seasons, in regions with extended dry hot seasons, and at low altitudes in tropical areas with consistent high temperatures (Bean \& Russo, 1986).

Eucalyptus globulus plantings in California range from Humboldt to San Diego and from Redding south through the central valley into Fresno, Bakersfield, and San Bernardino (Skolmen \& Ledig, 1990). It was especially valued as a windbreak in the mostly treeless central valley (Steinmaus et al., n.d.). Trees were planted for windbreaks and property boundaries on lands now designated for national parks and other natural areas (National Park Service, 2006). Eucalyptus globulus also grows in parks, yards, and other urban areas where low maintenance landscape is desired. Many E. globulus stands were abandoned when eucalypt interest waned, and many exist in areas suitable for spread with optimal ecoclimatic conditions or near riparian habitat (Steinmaus et al., n.d.). 


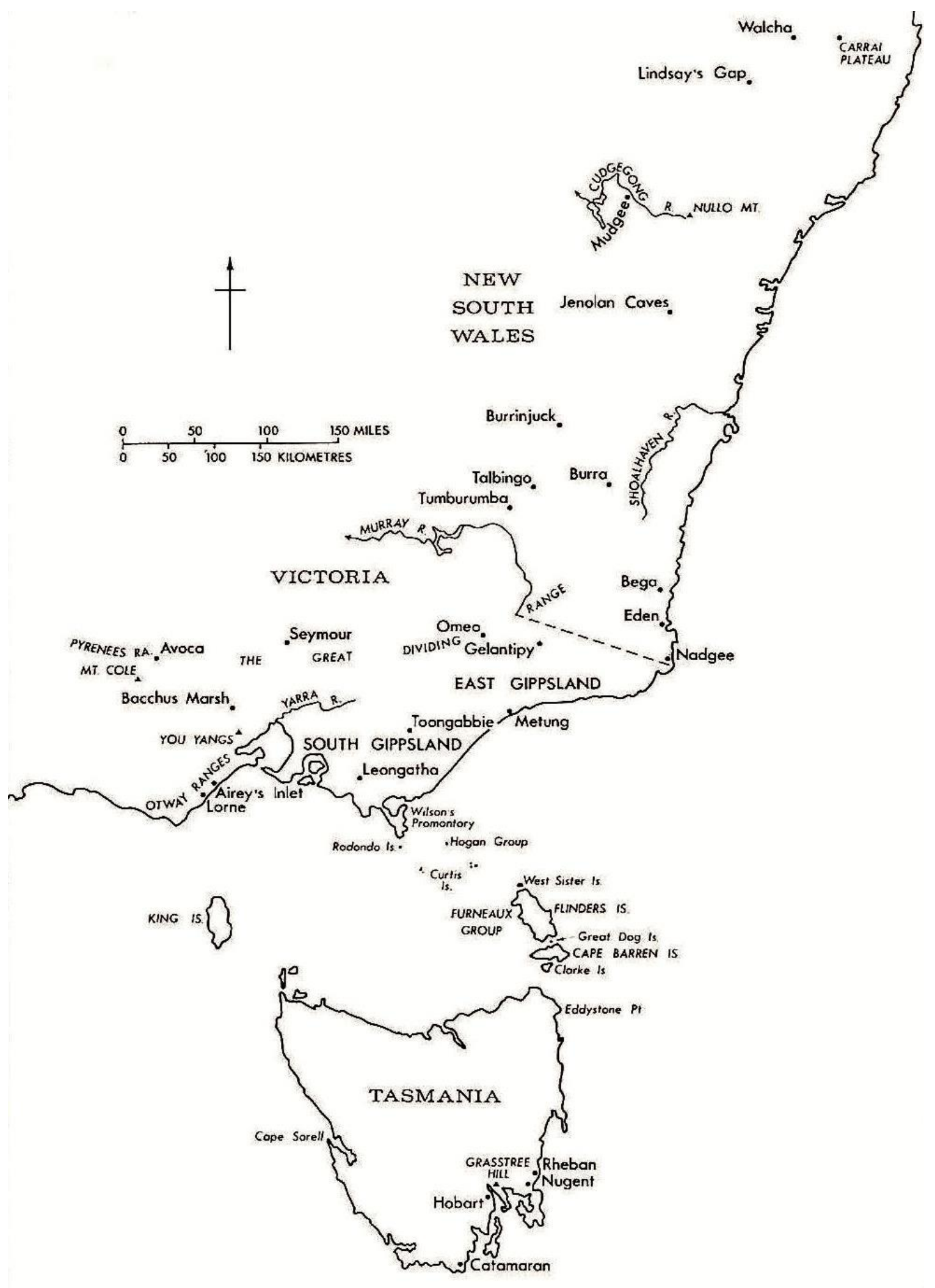

Figure 4. Locations mentioned in the text. Figure from Kirkpatrick, 1975. 
Eucalypts' fast growth and biomass production have recently garnered attention for use as biofuels feedstock, and both propagule pressure and local invasion probability could increase with widespread use (Rejmánek \& Richardson, 2011). Eucalypts are grown for biomass, pulpwood, and firewood (California Agriculture, 1996). Eucalyptus globulus has been used for fence posts, poles, mining timber, erosion control, and as an ornamental landscape species (Bean \& Russo, 1986; Food and Agriculture Organization of the United Nations, 1979). Eucalyptus globulus is a promising low cost source of hardwood fiber and still widely used for fuel, shelter, and windbreaks (Krugman, 1970). Eucalyptus globulus is also considered to have commercial pulp wood potential (Schofield et al., 1989).

Eucalyptus globulus trees are used for windbreaks because they are wind-firm (strong root anchorage), unpalatable to most grazing animals, and coppice vigorously after hedging (Food and Agriculture Organization of the United Nations, 1979; Skolmen \& Ledig, 1990). Eucalypts' open crowns do not form a complete wind barrier, but shoots fill space with repeated coppicing (Jacobs, 1955). Widely spaced, openly grown trees strengthen themselves against wind sway by developing stout trunks and root systems, and trees grown closer together have slender form with less taper (Jacobs, 1955). Eucalyptus globulus windbreaks are most effective when grown with smaller trees and shrubs (Metcalf, 1968).

Crop protection is crucial for some crops in California (Santos, 1997). Windbreaks enhance productivity by protecting crops, livestock, and soil and water resources. Windbreaks also conserve energy by improving irrigation efficiency (USDA National Agroforestry Center, 1994a). Windbreaks reduce wind erosion and increase bee 
pollination and pesticide effectiveness (USDA National Agroforestry Center, 1994a; USDA National Agroforestry Center, 1994b). Tree windbreaks moderate hot, dry wind and can increase row-crop productivity by 10 to $25 \%$ in dry climates by moderating increased crop evaporation and transpiration (USDA National Agroforestry Center, 1994a). However, windbreak tree roots will rob and stunt the protected crop if eucalypts are not adequately watered (Santos, 1997).

Eucalyptus globulus has great climatic adaptability but grows best in Mediterranean climates with cool, wet winters and warm, dry summers (Skolmen, 1983; Skolmen \& Ledig, 1990). Other species cannot compete with E. globulus on locations with optimal climatic suitability (Skolmen \& Ledig, 1990). Brown (as cited in Bean \& Russo, 1986) proposes that the absence of plant life under trees is partly due to E. globulus outcompeting other plant species. Eucalyptus globulus grows best on deep alluvial soils (soils deposited over floodplains by running water) with greater moisture supply in California and other locations with distinct dry seasons. Eucalyptus globulus does well with nominal rainfall and pronounced dry seasons in coastal California largely because frequent fog compensates for rain (Skolmen \& Ledig, 1990). Fog drip under coastal populations can be substantial and accounts for their regeneration ability. Clarke, Fisher, $\&$ LeBuhn (2008) found summer fog drip from eucalypts added water amounts comparable to annual rainfall and significantly alleviated consumption. Its aggression may also be indirectly due to tolerating both high salinity and low nutrient areas (Bell \& Williams, 1997).

Coastal fog is an important climatic factor for vegetation. It occurs on foothills and mountains of coastal and interior valleys and is more frequent during spring and summer 
months than autumn and winter. Typical summer days in California coastal valleys are characterized by morning fog which clears by mid-morning and hot, dry afternoons (Hanes, 1971). Relative humidity reached $100 \%$ on one third of summer mornings in coastal southern California mountains (Hanes, 1965).

Although E. globulus' range is widespread in California, its presence is typically due to purposeful cultivation. It invades scrub and chaparral, grassland, bog and marsh, riparian, and forest ecotypes although spread into dense forest vegetation is unlikely (California Invasive Plant Council, 2015a). Eucalyptus globulus, once established with adequate moisture, spread invasively, displace native vegetation, and alter ecological processes. Its ability to survive management and immediately sprout from the base, trunk, stumps, lignotubers, and roots after injury has led to a variety of treatment strategies (Boyd, 2000; National Park Service, 2006). All management strategies are complex with substantial costs and benefits, but taking no action also brings serious consequences (National Park Service, 2006).

Introduction risks have greatly accelerated with increased air travel, ports of entry, international trade, and access to foreign ecosystems (Mullin et al., 2000). California's moderate climate, active international trade, diverse agriculture, and tourism make it particularly susceptible to exotic species invasion (Steinmaus et al., n.d.). Scientists from the Nature Conservancy and the Association for Biodiversity highlighted California as a hot spot of American biodiversity, where the rarest species are most concentrated and endangered (Stolzenburg, 2000). Pryor (1976) acknowledged the continual replacement of one species by another and species extinction as biological life history but also highlighted human involvement in the change rate increase this century. 
The main legislation restricting plant species entry and spread into the United States is the Federal Noxious Weed Act, however, it historically only lists a plant species after it is already widely established, has done substantial damage, and become extremely difficult to manage (Reichard \& Campbell, 1996). Reichard and Campbell (1996) also note the act only includes a small percentage of invasive plant species. They estimate 750 species meet the noxious weed definition, but only 94 species are listed. A comprehensive proactive policy establishes invasive potential before spread and considers plant problems in natural areas and on commodity-managed lands (agricultural or rangeland) equally. Determining invasive potential before introduction or spread is the most difficult aspect of changing from a reactive approach to a proactive one (Reichard \& Campbell, 1996).

\section{Reproduction and development}

Eucalyptus globulus reproduces by seed and sprouting. Flowering occurs throughout the winter (November to April) in California, and seed set begins at 4-5 years of age (Krugman, 1974; Skolmen \& Ledig, 1990; Turnbull \& Pryor, 1978). Flowers provide nectar and pollen for honey production and are pollinated by insects, hummingbirds, and other pollen and nectar feeders (Skolmen \& Ledig, 1990; Rejmánek \& Richardson, 2011). The fruit ripens about one year after flowering, capsules release seed immediately, and seed is wind dispersed (Krugman, 1974; Skolmen \& Ledig, 1990).

The white flowers are solitary, occur on flattened stalks in axils, and are approximately $4-5.5 \mathrm{~cm}$ wide. Flower sepals and petals are united and form a warty lid on the bud that drops off at anthesis (the period that a flower is open). The flowers contain many stamens, and the ovary is four-loculed with many ovules (Bean \& Russo, 
1986). The anthers contain mature pollen when the cap covering the reproductive organs (the operculum) is shed, but the stigma does not become receptive until days later, impeding self-pollination of individual flowers (Bean \& Russo, 1986).

Solitary fruit $(2-2.5 \mathrm{~cm})$ are sessile, hard, woody, warty, glaucous, globose or topshaped, (usually) four-ribbed capsules with a broad, thickened flat or convex disc (Figure 5) (Hall, Johnston, \& Chippendale, 1970; Krugman, 1974). The fruit is dehiscent by four valves. Eucalypts scatter seed from attached capsules or seed spills out of capsules that fall to the ground intact (Bean \& Russo, 1986). Seeds are numerous, dark brown with brownish red chaff, and approximately 2 x $1 \mathrm{~mm}$ (Krugman, 1974).

One ounce of fruit contains 2,500 viable seeds plus chaff (unfertilized ovules and other dry material around the developed seed) on average (Krugman, 1974). However, viable seed bank maintenance is not expected beyond a year in field conditions (Rejmánek \& Richardson, 2011). Also, seed on soil surface is drastically reduced by predation if forest floor cover is provided because the ground cover protects seed predators (Steinmaus, 2002d). Accelerated seed shed satiates seed predators (Gill, 1997).

Accelerated seedshed occurs after fire; even when crowns are only heat scorched (Christensen, 1971; Cremer, 1965). Eucalypts' crown flammability creates high temperatures for short durations, and seed capsules protect seed for the critical period when fire reaches tree crowns (Ashton, 1981). Fire also exposes bare ground, reduces competition, increases light, and sometimes improves soil moisture status (Gill, 1997). Eucalypts takes advantage of competition reduction and exposed soil available after fire (National Park Service, 2006; Williams, 2002).

Eucalypt seeds are very small and not adapted for dispersal (Rejmánek \& Richardson, 


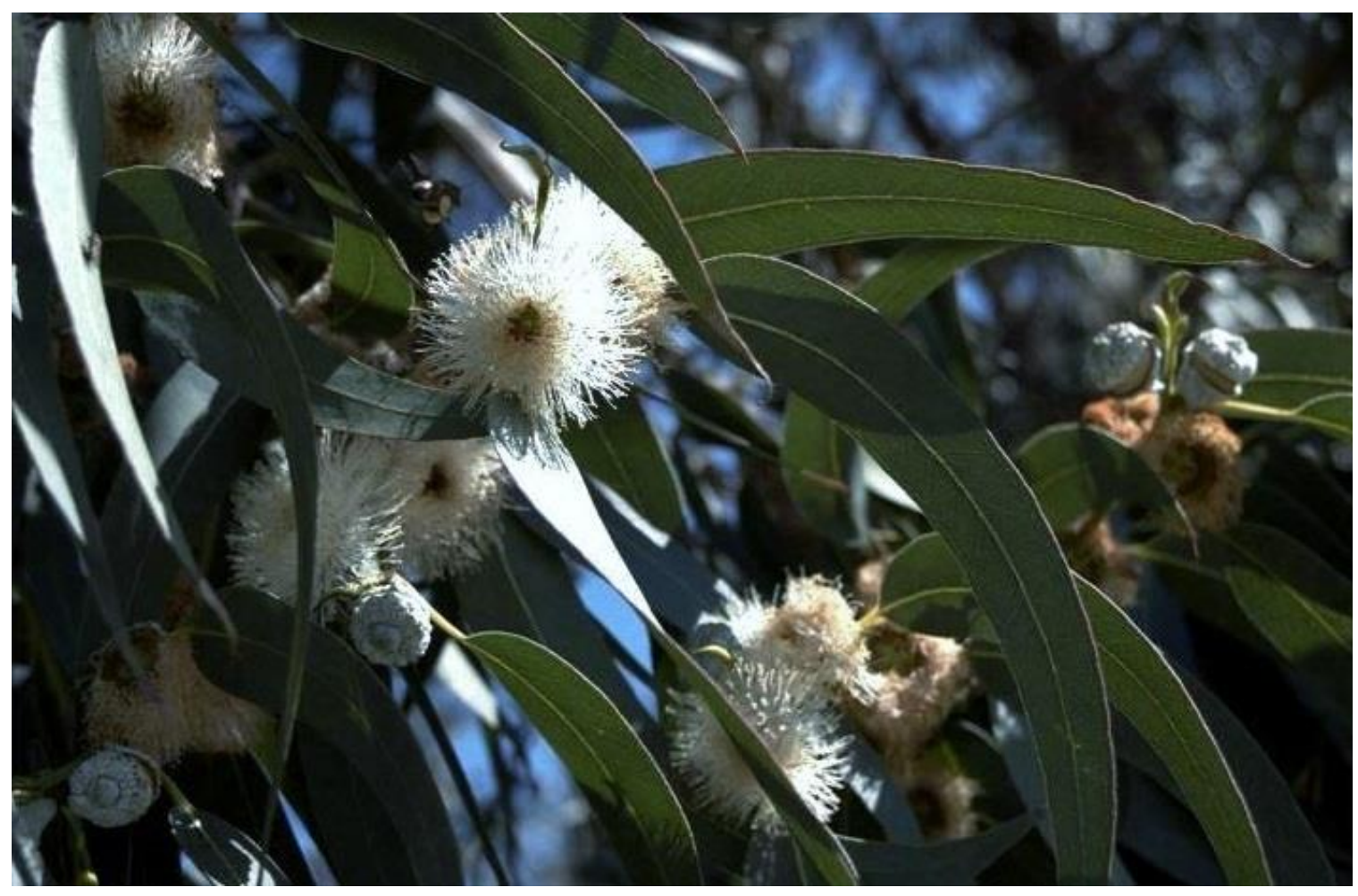

Figure 5. Mature leaves, seed capsules, and flowers of E. globulus. Montaña de Oro State Park, Los Osos, Ca. November 27, 2015.

2011). Invasion opportunity begins with seed dispersal, and relative limited seed dispersal seems to be a major reason for the limited invasiveness of eucalypts (Radosevich, Holt, \& Ghersa, 1997; Rejmánek \& Richardson, 2011). Passive release of seed is aided by wind and gravity, but seeds are dispersed over short distances in general (Jacobs, 1955; Rejmánek \& Richardson, 2011). In fact, most seed is dispersed within 100 feet of parent trees (Jacobs, 1955). Large concentrations of seed are easily eaten (optimal foraging) by seed predators often resulting in significant seedling mortality near the mother plant (Steinmaus, 2002d).

Recruitment is the transition of seeds and seedlings to independent, reproducing adults (Radosevich et al., 1997). Seedling recruitment into a population is a function of 


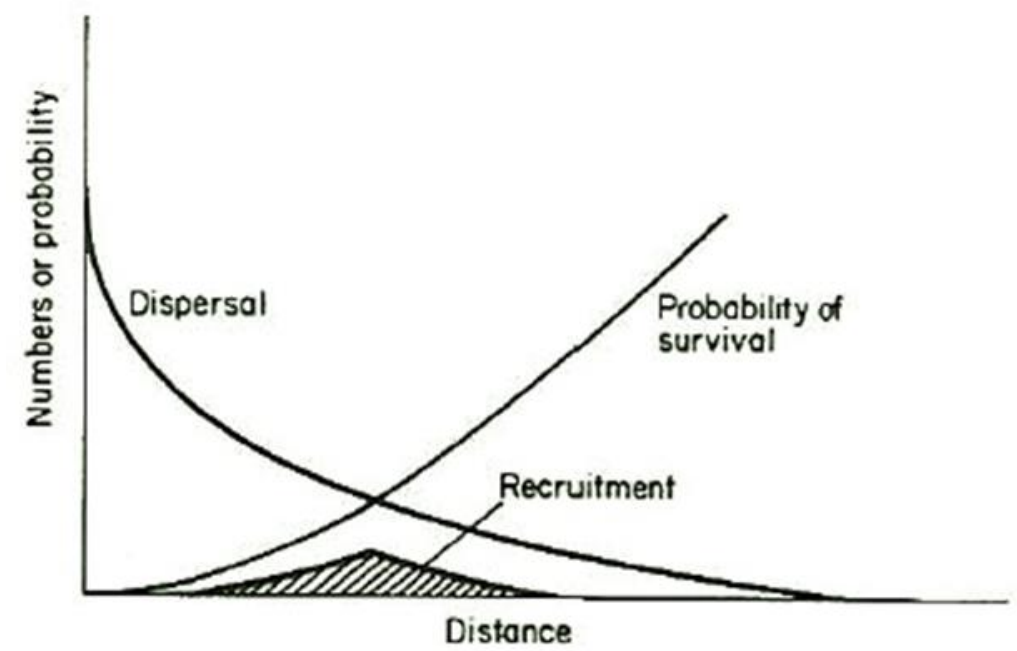

Figure 6. Seedling recruitment as a function of dispersal and survival (Cook, 1980).

dispersal and survival (Figure 6) (Cook, 1980). The product of seed dispersal and seedling mortality is the optimal distance between neighboring individuals and results in a creeping infestation (Cook, 1980; Radosevich et al., 1997). Seed dispersal is generally concentrated below or close to the parent tree, and the concentration decreases as distance from the parent tree increases. Seed dispersal adaptations increase seed and seedling survival by removing individuals from sources of parental mortality. Although the amount of widely dispersed seed is low relative to total seed production, trees from widely dispersed seeds colonize individually, reach high densities, and spread as advancing fronts (Radosevich et al., 1997).

Flood, erosion, and birds can facilitate spread beyond adjacent areas (Jacobs, 1955). Running water can spread eucalypt seeds long distances (Rejmánek \& Richardson, 2011). Seeds may raft down flood streams and be deposited when flood waters recede. Flood water may also remove competition from established plants. This is a probable mechanism for long distance dispersal because isolated E. globulus trees often grow near 
streams (Kirkpatrick, 1975). However, since eucalypt seeds are not adapted for dispersal and mainly fall near the parent tree, long distance dispersal is primarily anthropogenic (Lanini, DiTomaso, \& Norris, 2002; Rejmánek \& Richardson, 2011).

Irrigation practices are also an important factor for seed dispersal. Most seeds float and therefore require no dispersal adaptation. Seed can also move along the bottom of water flow. Eucalyptus globulus trees used for windbreaks and/or growing near canals drop seed into the water, and irrigation moves and deposits seed in fields (Lanini et al., 2002).

Seeds spread by water find temporarily flooded or eroded banks suitable habitat for establishment (Rejmánek \& Richardson, 2011). Seedling roots require suitable wet substrate quickly, so eucalypts only successfully establish from seed on wet, bare soil (Rejmánek \& Richardson, 2011). Germination rates are typically very low but establishment can be significant after disturbance (e.g. fire) or harvesting operations (Krugman, 1974; Rejmánek \& Richardson, 2011; Skolmen \& Ledig, 1990).

Eucalypts produce seeds with no obvious endosperm, so seedlings are sustained by cotyledon photosynthesis. However, eucalypt seedlings are tiny and establishment within groves is inhibited by dense vegetation, forest litter, and duff (Krugman, 1974; Rejmánek \& Richardson, 2011; Skolmen \& Ledig, 1990). Thick litter layers also suppress germination of both E. globulus seedlings and other plants (May \& Ash 1990).

The percentage of seeds establishing into seedlings is usually small and widely variable (Gill, 1997). Seed collections from individual trees in California had highly variable germination rates ranging from 2 to $80 \%$ within a 30-day period (Krugman, 1970). Successful seedling establishment from seed typically occurs after fire although 
eucalypts can geminate and establish without fire. The combination of mass seed release, reduced competition, and altered microenvironment facilitates successful establishment from seed after fire (O’Dowd \& Gill, 1984; Wellington \& Noble, 1985a; Wellington \& Noble, 1985b). Although germination rates are typically very low, E. globulus seedlings often survive and significantly invade neighboring plant communities (Boyd, 2000; Jacobs, 1955; California Invasive Plant Council, 2015a).

Although E. globulus does not require light for mature seed to germinate, seedling establishment is affected by shading, litter accumulation, drought, plant competition, frost, and insect and fungal attack (Clifford, 1953; Gill, 1997). Eucalyptus globulus is not shade tolerant, and failure to regenerate without fire is related to low light intensity (Ashton, 1981; Boyd, 2000; Skolmen \& Ledig, 1990). High seedling mortality may be another reason for the limited invasiveness of the genus (Rejmánek \& Richardson, 2011).

Seedling and juvenile leaves are born horizontally on squared stems, opposite (for many pairs), ovate or broadly lanceolate, glaucous (covered with white wax), sessile (attached directly without a stalk or peduncle), nearly twice as long as they are broad. Mature leaves are born spirally on rounded stems, alternate, narrowly lanceolate to lanceolate, often curved, dark green, thick and leathery, petiolate (stalked), and hang vertically (Hall, Johnston, \& Chippendale, 1970; Johnson, 1926; Penfold \& Willis, 1961; Ritter, 2011). Venation of adult leaves is moderately conspicuous with lateral veins at 30-45 angles with the midrib (Hall et al., 1970; Penfold \& Willis, 1961).

The bark of E. globulus is smooth above the base but rough, grey, and persistent at the base (Food and Agriculture Organization of the United Nations, 1979; Penfold \& Willis, 1961). Its stringy bark is thick, fibrous, furrowed, and interlaced beneath the 
surface (Boyd, 2000; Ritter, 2011). The rhytidome (true bark) is shed late in summer or early autumn (Penfold \& Willis, 1961). Long strips of partly shed bark remain in the crown, drape down the stem (ribbony), and leave a smooth, bluish grey surface when it peels off (Hall et al., 1970; Ritter, 2011).

Eucalyptus species with deciduous bark are grouped together as "gum trees" and are characterized by smooth bark (Food and Agriculture Organization of the United Nations, 1979; Penfold \& Willis, 1961). They are called gum trees because of dark, astringent, resinous exudations, kino, which impregnates dead bark (Penfold \& Willis, 1961; Ritter, 2011). Kino is found in sealed reservoirs inside trees and in the veins and pockets of timber (Penfold \& Willis, 1961).

Ducts containing kino form large pockets, extend vertically in eucalypt wood, and are known as "gum veins" (Penfold \& Willis, 1961). Gum veining occurs when the wood cambium is damaged (fire, insects, branch shed, or mechanical injury) (Jacobs, 1937). Veining is also associated with epicormic growth. Gum veins affect timber appearance, grading, and price (Penfold \& Willis, 1961).

Kino flows freely when reservoirs are ruptured, and brown or reddish masses of kino is usually visible on tree bark. Viscous liquid kino may appear jelly-like or glass-like as it hardens (from air exposure) and becomes a brittle mass (Penfold \& Willis, 1961). Despite eucalypt kino containing mainly tannins, tannins being commonly associated with plant protection, and kino only collecting after live bark injury, its purpose is not completely understood (Penfold \& Willis, 1961; United States Department of Agriculture Forest Service, n.d.).

Eucalyptus globulus reaches heights of 260 feet in California (National Park Service, 
2006). The tallest flowering plant in North and South America is a specimen of Eucalyptus globulus on Santa Cruz Island in Santa Barbara county measuring $75.05 \mathrm{~m}$ (246.2') tall (Ritter, 2012). The trunk grows vertically and forms a well-developed crown at two thirds of total height (Bean \& Russo, 1986). $60-70 \%$ of total height is usually reached within the first decade, and rapid growth is one main reason E. globulus has been grown on plantations (National Park Service, 2006).

Its root system consists of mainly lateral roots, and the main root axis (tap root) rarely exceeds 10 feet in length (Sellers, 1910). Eucalyptus globulus produces extensive roots throughout the soil profile, and this deep rooting is important for seedling water uptake (Skolmen \& Ledig, 1990; Stoneman, 1994). Strong lateral roots near the surface frequently extend over 30 meters from the trunk, and roots can penetrate depths of 14 meters in deep soils with high water tables (DiTomaso \& Healy, 2007; Sellers, 1910). Eucalyptus globulus has also been used for wetland conversion because its rapid growth accompanies rapid water uptake (National Park Service, 2006).

Eucalyptus globulus' extraordinary uptake alters groundwater availability (California Invasive Plant Council, 2015a). Eucalyptus globulus roots grow quickly toward water, so they should never be planted in sandy or gravelly soils or near wells, water pipes, irrigation ditches, or cisterns/reservoirs (Figure 7) (Sellers, 1910). DiTomaso and Healy (2007) attributed the ability of E. globulus to survive prolonged, dry summers by reaching deep water reservoirs and economizing use by stomatal control. 


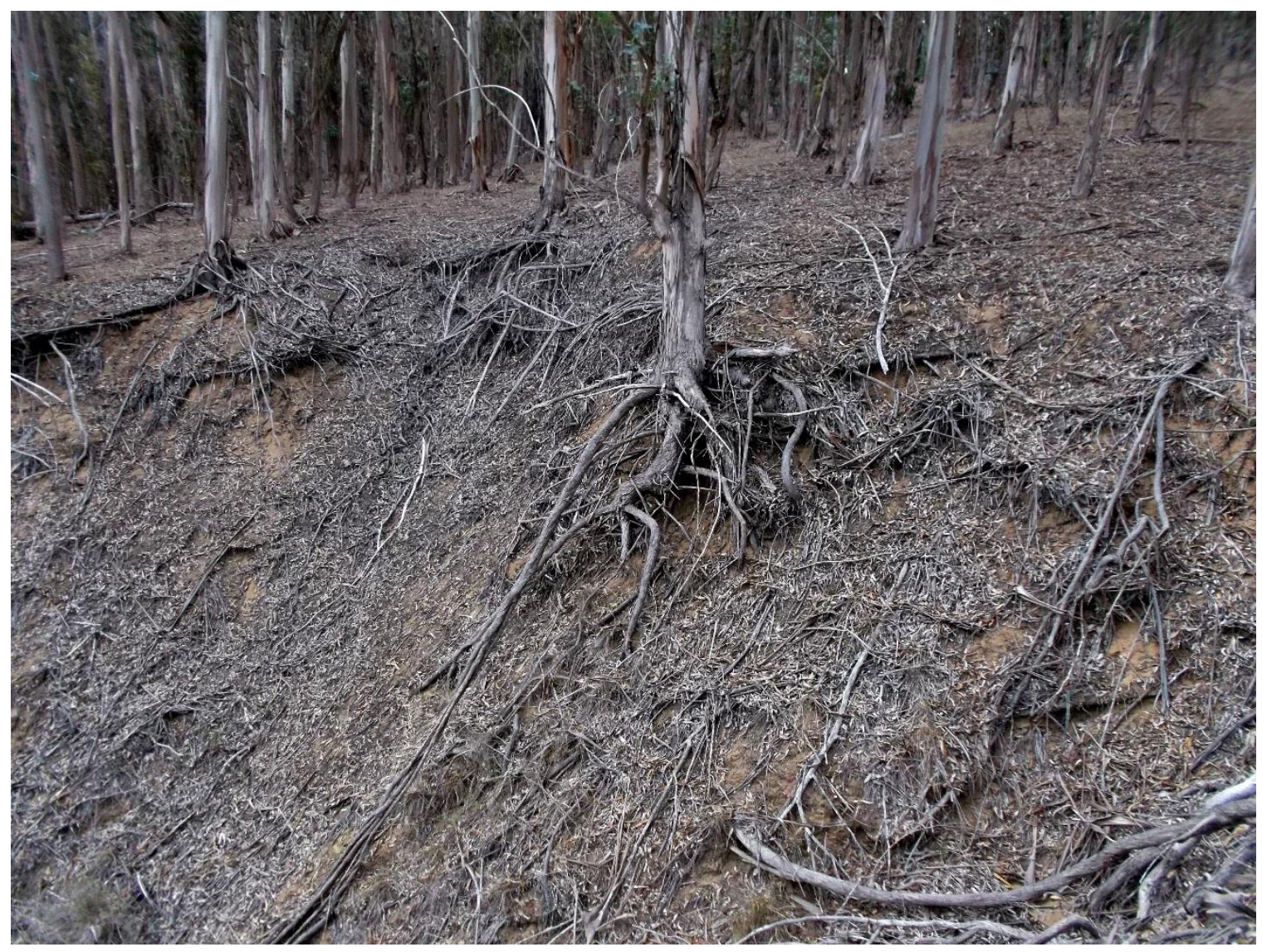

Figure 7. Exposed root systems of E. globulus. Montaña de Oro State Park, Los Osos, Ca. November 27, 2015.

\section{Damaging agents}

Fire

Eucalyptus globulus trees are highly susceptible to fire during the California dry season (Skolmen \& Ledig, 1990). They are also highly resistant to fire. Fire easily damages young trees but rarely kills them (Turnbull \& Pryor, 1978). California fires are intense and difficult to control. Accumulated litter renders dense eucalypt stands extremely flammable, and conditions are amplified after winter freezes when trees drop dead branches and foliage (Rejmánek \& Richardson, 2011). 
For example, the East Bay Hills Fire in 1991, the worst wildfire in California history, was partially due to the high density of eucalypts (National Park Service, 2006). Frigid arctic air plunged temperatures to record lows along coastal California during the last weeks of 1990, and fuel accumulation in unmanaged eucalypt stands likely contributed to the intensity of the fire in October 1991 (Rejmánek \& Richardson, 2011). It was estimated that over $70 \%$ of the energy released through the combustion of vegetation was due to eucalypts. The fire killed 25 people, injured 150 others, destroyed 2,900 structures, burned over 3,000 acres, and caused damage totaling $\$ 1.5$ billion. Wildfire containment is nearly impossible in eucalypt forests (National Park Service, 2006).

Eucalyptus globulus' physical characteristics, including open canopies and long swaying branches, encourage updraft (National Park Service, 2002). Its deciduous bark peels off in long strips during late summer or early fall (Penfold \& Willis, 1961). Partly shed bark hangs in the tree crown and drapes drown the trunk (Figure 2) (Ritter, 2011). Annual bark shedding presents a significant fire hazard because hanging strips of bark catch fire easily and spread fire into tree crowns (National Park Service, 2006; Skolmen \& Ledig, 1990). Eucalypts are considered the worst in the world for igniting spot fires because burning bark drifts away in high winds and spreads fire considerable distances (Boyd, 2000; Jacobs, 1955). Shedding usually happens in hot weather (Jacobs, 1955). This is especially problematic in California because bark shedding coincides with peak wildfire season.

Chemicals in E. globulus leaves also play an important role in fire behavior. Oils in eucalypt leaves contain three times more energy than cellulose and consequently burn hotter. Eucalypt leaves also release terpenes and phenolic acids. These volatile 
flammable gases ignite easily and catalyze (cause or accelerate) combustion (Rice, n.d.).

Frost

Eucalyptus globulus is moderately frost hardy (Esser, 1993). Frost resistance increases with maturity, but seedlings are not frost tolerant and temperatures of $-5^{\circ}$ to $10^{\circ} \mathrm{C}\left(23^{\circ}\right.$ to $\left.14^{\circ} \mathrm{F}\right)$ usually kill them (Chen \& Yang, 1987; Skolmen \& Ledig, 1990). Eucalyptus globulus seedlings are very sensitive to frost, drought, and fungal and insect attack. Eucalyptus globulus remains extremely frost sensitive while immature foliage is retained (Bean \& Russo, 1986). Regions where E. globulus is an exotic are more frost tolerant than Australian provenances (Almeida, Pereira, Miranda, \& Tomé, 1995).

Frost survival is achieved through avoidance and freezing tolerance (Larcher, 1995; Nilsen \& Orcutt, 1996). Avoidance mechanisms include supercooling and metabolic heat production. During supercooling, solutes accumulate in cells and lower cytoplasm freezing point by either metabolically synthesizing solutes or by moving water to less sensitive areas. Metabolic heat elevates temperatures to prevent freezing (Nilsen \& Orcutt, 1996).

Freezing tolerance mechanisms allow icing in plant tissues without lethal consequences and usually involve extracellular ice formation (Larcher, 1995; Nilsen \& Orcutt, 1996). Levitt (1980) concluded sugars play some role in the freezing tolerance mechanism and may increase freezing tolerance in two ways. Sugars can accumulate in the vacuole, decrease the amount of ice formed, and therefore increase avoidance of freeze induced dehydration. Sugars are also metabolized in the protoplasm at low, hardening temperatures and produce unknown protective changes. Accumulation of soluble sugars serves as a cryoprotectant mechanism to avoid protein denaturation and 
membrane disruption from dehydration during ice formation (Alden \& Hermann, 1971; Levitt, 1980; Parker, 1963; Tinus, Burr, Atzmon \& Riov, 2000). Eucalypts commonly respond to soil moisture by rapidly absorbing and transpiring water when readily available and 'shutting down' during drought (Bell \& Williams, 1997). However, Florence (1996) characterized eucalypts as generally drought tolerant rather than drought avoiding because they maintain tissue function despite large water potential decline.

\section{Drought}

Eucalypt seedlings are susceptible to drought for weeks after germination, and dessication is the primary cause of seedling death (Penfold \& Willis, 1961). Perennial tree seedlings, like eucalypts, resist drought mainly by postponing dehydration by maintenance of turgor or volume (Stoneman, 1994). Turgor maintenance may be achieved by maintenance of water uptake, reduction of water loss, or osmotic adjustment. Volume maintenance is achieved by increase in tissue elasticity (Turner, 1979; Turner, 1986). A range of plant species, including eucalypts, have the capacity to regulate osmotic potential and cell wall elasticity in response to drought (Abrams, 1990; Bowman \& Roberts, 1985a; Bowman \& Roberts, 1985b; Cheung, Tyree, \& Dainty, 1975; ClaytonGreene, 1983; Melkonian, Wolfe, \& Steponkus, 1982; Myers \& Neales, 1986; Robichaux, Holsinger, \& Morse, 1986). Some survive drought by stomatal control or rapidly producing massive root systems in drying soil profiles (Awe, Shepherd \& Florence, 1976; Moreshet, 1981).

Eucalypts are physiologically adapted for drought resistance because most are native to areas with water shortage for substantial periods. Florence $(1981,1996)$ generally characterized eucalypts as 'drought tolerant mesophytes' because they tend to maintain 
transpiration and cell metabolism under drought conditions. Eucalypts develop hard tissue and avoid lasting drought damage because the hard, woody sclerenchyma tissue confers wilting endurance. However, eucalypts do not economize water use; instead, their extensive root systems extract water from soil at higher moisture tensions than more mesophytic plants. Stomatal closure (drought avoidance) occurs after severe, permanent wilting, and the water loss inhibition enables critical water balance scenario survival (Pryor, 1976). Florence (1996) described the strong root system and lignotuber development of eucalypt seedlings as adaptations important for competition, survival, and subsequent dynamic growth in low nutrient soil and dry climate.

Eucalyptus globulus' extensive root structure and riparian habitat preference threatens water flow in seasonal streams and creeks, and its extraordinary water uptake threatens water availability (National Park Service, 2006; Steinmaus et al., n.d.). Roots along the water edge reduce flow, increasing sedimentation and raising the water bed (Steinmaus, 2007). Flow reduction further threatens ecological stability by increasing water temperature and causing fish die-off because warmer water holds less dissolved oxygen (California Invasive Plant Council, 2015b; Steinmaus, 2002a; United States Geological Survey, 2015). Consequently, impeding water flow threatens the diversity or abundance of native fish species and dependent native fauna (United States Fish and Wildlife Service, 2012a).

Drought has made Californians conscious of water conservation. Eucalypts in California extract more water than ecologically comparable evergreen California chaparral species and broad leaved Mediterranean species (Pereira \& Chaves, 1993; Poole \& Miller, 1975). Eucalyptus globulus is drought tolerant (Esser, 1993) but is 
particularly susceptible to drought on shallow soils (Skolmen \& Ledig, 1990).

\section{Salinity}

Eucalypts have also found popularity because they inhabit areas with high salt concentrations where other tree species will not grow (Bell \& Williams, 1997; California Agriculture, 1996). High salt concentrations are frequently found in coastal and inland Australian soils (Eldridge et al., 1993). Eucalypts, because of ability to cope with saline stresses, are planted along the coastal shores of the Mediterranean to break saline wind, adsorb saline water, and potentially drain soils for agricultural or tourism purposes (Loreto \& Delfine, 2000).

Bennett and George (1995) found E. globulus can survive moderate soil salinities and also appears able to survive high soil salinity levels although growth is affected at much lower salinities. Waterlogging reduces the salinity level required to cause growth reductions (Bennett \& George, 1995). Ability to restrict uptake of ions and sequester excess ions into older shoot tissue has been noted in relation to salinity tolerance in eucalypts (Marcar, 1993; Marcar \& Termaat, 1990; van der Moezel, Watson, PearcePinto, \& Bell, 1988). Eucalyptus globulus has been identified as suitably adapted for salinity control on well drained soils in southwest western Australia (Schofield et al., 1989). Eucalyptus globulus does not naturally occur on poorly drained soils or on highly alkaline or calcareous soils (Bean \& Russo. 1986).

\section{Animals}

Eucalyptus globulus seedlings are susceptible to browsing by rabbits, possums, and wallabies, but their glaucous juvenile foliage is seldom browsed by cattle, sheep, or goats 
(Jacobs, 1970; Turnbull \& Pryor, 1978). Seedlings are also often severely girdled by rodents (Skolmen \& Ledig, 1990). Jacobs (1970) was convinced the unpalatability of its juvenile foliage is the reason for E. globulus' success abroad and widespread popularity. Seedlings achieve competitive advantage over other species where fencing is not practicable (Jacobs, 1970). Eucalyptus globulus seedlings can be grown without fences; a great benefit when raising forest crops. Also, this important economic advantage is probably the reason for E. globulus' popularity in the Mediterranean early in the Nineteenth Century (Food and Agriculture Organization of the United Nations, 1979). Animals that do not graze seedlings do, however, trample them (Skolmen \& Ledig, 1990).

Insects and fungi

Several insects attack E. globulus (Skolmen \& Ledig, 1990). The Eucalyptus longhorned wood borer, Phoracantha semipunctata F. (Coleoptera: Cerambycidae), is a common pest and has caused severe damage in Western Australia and South Africa (Neumann \& Marks, 1976). Snout beetles (Gonipterus spp.) feed on leaves and have caused severe damage in New Zealand, South America, and South Africa. The gum tree scale, Eriococcus coriaceus Maskell (Hemiptera: Sternorrhyncha: Eriococcidae), has caused high mortality and greatly reduced planting in New Zealand (Turnbull \& Pryor, 1978). The scale sucks the sap and causes branch dieback. Photosynthesis and growth are affected when leaves become covered with sooty mold, which grows on the honeydew excreted by the insects. Sooty mold is the common name given to several species of fungi which grow on honeydew secretions because the fungi's dark mycelium resembles a layer of soot. Coated leaves also prematurely age (senesce), die, and drop, 
and a severe attack can kill trees (Laemmlen, 2014). de Boer (as cited in Turnbull \& Pryor, 1978) reported defoliating insects (Chrysophtarta spp. and Mnesampela spp.) also attack E. globulus and have damaged plantations in northern Tasmania.

Insects had not been a serious problem for E. globulus in California before the accidental import of pests from Australia (California Agriculture, 1996; Skolmen \& Ledig, 1990). The Eucalyptus longhorned borer was introduced to Orange County in 1984, the blue gum psyllid, Ctenarytaina eucalypti (Maskell) (Hemiptera: Sternorrhyncha: Psyllidae), located in Monterey County in 1991, and the Eucalyptus snout beetle, Gonipterus scutellatus Gyllenhall (Coleoptera: Curculionidae), found in Ventura County in 1994 (California Agriculture, 1996).

A second longhorned borer species, yellow phoracantha, Phoracantha recurva Newman, was discovered in southern California in 1995 and has spread throughout the state. Phoracantha recurva can kill eucalypts. Pesticides are generally ineffective for longhorned borer management. Biological pest management and improved cultural practices significantly reduced trees killed by $P$. semipunctata, however biological control has been less effective against $P$. recurva. Phoracantha recurva develops and completes generations faster than $P$. semipunctata. Cut wood, dying branches, and stressed (especially drought stressed) trees attract both beetle species. Eucalypts are often unmanaged or minimally managed without irrigation in California (Paine, Dreistadt, \& Millar, 2014).

Longhorned borers usually leave healthy trees alone, but a significant proportion of eucalypts are water stressed during hot summer months and susceptible to attack. After hatching, larvae tunnel into and feed beneath the bark. Holes in bark and/or oozing kino 
are common symptoms of damage. Infested trees have wilted or dry leaves and thin canopies. Tree bark cracks and becomes packed with frass (excrement) and wood shavings. Extensive feeding can girdle trees, and infested trees usually die within weeks (Paine, Dreistadt, \& Millar, 2014).

The blue gum psyllid stunts young trees by sucking plant juices and causing leaf loss (Kabashima, Paine, Daane, \& Dreistadt, 2014; New Zealand Farm Forestry Association, 2015). Sooty mold grows on honeydew excretion, and honeydew and wax secretion can also damage vegetation below infestations. Water stress also increases eucalypt susceptibility to psyllid attack (Kabashima et al., 2014).

Adult psyllids resemble small cicadas and are also known as jumping plantlice (Kabashima et al., 2014). Colonies of blue gum psyllids include all life stages (eggs to adults) throughout the year. Multiple females contribute to an egg mass stuck to the plant near developing buds and shoots. All four nymphal stages or instars secrete white, waxy filaments. A cottony mass of loose filaments aids in blue gum psyllid identification (Kabashima et al.; New Zealand Farm Forestry Association, 2015).

Eucalyptus snout beetles are greyish-brown weevils that feed and breed on eucalypts. Trees are defoliated and stunted by G. scutellatus feeding (European and Mediterranean Plant Protection Organization, 2005). Gonipterus scutellatus has elongated, snout-shaped mouthparts and clubbed antennae (University of California Statewide Integrated Pest Management Program, 2014a). Females oviposit for the duration of adult life, and one weevil can lay 800 eggs during that time (European and Mediterranean Plant Protection Organization, 2005; University of California Statewide Integrated Pest Management Program, 2014a). Eggs are deposited on young leaves and hatch in 10-20 days. Larvae 
feed on leaf tissue, fall to the ground, and pupate in soil. Adults emerge from pupation and also feed on foliage. Eucalyptus snout beetles complete 2-3 generations per year. An introduced parasitic wasp native to Australia, Anaphes nitens Girault (Hymenoptera: Mymaridae), delivers complete biological control of G. scutellatus in California (University of California Statewide Integrated Pest Management Program, 2014a).

Loss of seedlings or germinating seed is attributed to soil-dwelling and foliar parasitic fungi. Soil dwelling fungi are pathogenic seed and stem parasites (Penfold \& Willis, 1961). Eucalyptus globulus is moderately resistant to Phytophthora cinnamomi Rands (Pythiales: Pythiaceae) root rot, but seedlings are highly vulnerable to grey mold, Botrytis cinerea Pers. (Helotiales: Sclerotiniaceae) (Marks, Kassaby, \& Fagg, 1973; Turnbull \& Pryor, 1978). Damping off (underground, soil line, or crown rot) is prevalent in warm, wet conditions, and parasitic fungi (Botrytis, Colleotrichum, Cylindrocladium, Fusarium spp.) and water molds (Phytophthora and Pythium spp.) often kill seedlings (Penfold \& Willis, 1961; Rejmánek \& Richardson, 2011). Seedlings are killed before and directly after emerging and offer no resistance. Symptoms are seed decay, collapse before emergence, and decay at soil level. Powdery mildews and rusts are the foliar parasites (Penfold \& Willis, 1961).

Powdery mildew is caused by many species of fungi that survive as vegetative strands in buds or as spherical fruiting bodies, called chasmothecia, on perennial hosts and requires living plant tissue for growth (Gubler \& Koike, 2014). Windborne powdery mildew spores do not require moisture for development, and warm dry conditions encourage growth (Gubler \& Koike, 2014; University of California Statewide Integrated Pest Management Program, 2015). Thin layers of mycelium grow on the surface of plant 
parts. New buds, shoots, flowers, and leaves are covered with a white powdery growth and may be dwarfed and distorted. Spores produced in chains on leaf surfaces and/or on flowers, fruit, and stems are part of the white, powdery appearance (Gubler \& Koike, 2014). The white powdery spots spread, and leaves discolor (turn yellow or brown), twist or distort, and fall off (University of California Statewide Integrated Pest Management Program, 2015).

Rusts are dry, colored (brown, orange, purple, reddish, or yellowish) species of pathogenic fungi spore masses usually found growing under leaves (University of California Statewide Integrated Pest Management Program, 2014c). Windborne rust spores infect through stomata. Water (dew is sufficient) is required for germination and infection but is not needed for development. Infection and spore production continues for the duration of leaf life once it occurs (Koike \& Wilen, 2014). Upper leaf surfaces become spotted and discolored, and heavily infected leaves curl, senesce, and drop prematurely. Severe rust infections consequently stunt plant growth. Some rust species induce tissue swellings, galls, or cankers on woody plants resulting in stem dieback and eventual plant death (University of California Statewide Integrated Pest Management Program, 2014c).

\section{Adaptive traits}

Eucalyptus globulus is well adapted to invade coastal California ecosystems (Steinmaus, 2007). Eucalyptus globulus is native to the fire adapted ecosystems of Australia and recovers well from fire (Ashton, 1981; Steinmaus et al., n.d.). Eucalypts evolved with frequent fire and can refoliate crowns after defoliation and branch destruction (Food and Agriculture Organization of the United Nations, 1979). 
Indefinite shoots and naked buds permit eucalypt shoots to grow continuously in favorable conditions. Delicate growing tips grow in height or length indefinitely and keep producing pairs of leaves and new orders of branches (Food and Agriculture Organization of the United Nations, 1979). In every eucalypt leaf axil is a stalked bud known as a naked bud (Penfold \& Willis, 1961). They become visible when leaves unfold and are called naked buds because they are not covered by protective bud scales (Carey, 1930). Naked buds near shoot tips develop simultaneously and give rise to first branches. First order shoots produced by naked buds unfold leaves containing additional naked buds which will produce second order branches with the same capacity (Penfold \& Willis, 1961). The development of naked buds is inhibited by a hormone (or hormones) produced at shoot apexes, and naked buds will only grow when shoot tips are destroyed or removed (Bean \& Russo, 1986). The naked bud can immediately produce a branch of the next order or become the main shoot if the mother growing tip is destroyed (Food and Agriculture Organization of the United Nations, 1979). Although naked buds have the potential to produce new shoots when new leaves unfold, excess shoots are suppressed/shed and the crown maintains an open structure with 4-5 orders of branches (Food and Agriculture Organization of the United Nations, 1979).

Adaptive traits enable eucalypt survival after damage to aerial plant parts (Cremer, 1962; Jacobs, 1955). Eucalypts evolved to rapidly grow during favorable periods, and recover from harsh environmental conditions (Eldridge et al., 1993). Naked buds in every eucalypt leaf axil are capable of rapid development when leaves unfold (Florence, 1996). Naked/axillary buds, accessory buds, and lignotubers sprout new, leafy shoots and rapidly replace eucalypt crowns after defoliation (Cremer, 1972; Eldridge et al., 
Jacobs, 1955). Naked buds represent remarkable growth potential, and eucalypts build crowns unusually fast in comparison with most trees which produce a single order of branches per year (Jacobs, 1955; Penfold \& Willis, 1961). This ability is due to naked buds and indefinite shoots (Food and Agriculture Organization of the United Nations, 1979; Jacobs, 1955). Accessory and dormant bud reserves enable comparatively fast, elaborate foliage production (Penfold \& Willis, 1961).

Eucalypts also contain accessory bud-producing tissues called proventitious bud strands in leaf axils between the naked bud and the petiole base. This pad of meristematic tissue also grows new leafy epicormic (below bark) shoots called accessory buds in the leaf axil if the original naked bud, young shoots, and/or upper leaves are removed (Bean \& Russo, 1986; Food and Agriculture Organization of the United Nations, 1979; Ritter, 2012). This adaptation further allows eucalypts to survive complete defoliation by fire, which is common in Australian forests (Bean \& Russo, 1986). This aggressive replacement mechanism also counteracts attacks by insects, mammals, or fungi on tender terminal and axillary buds/shoots (Food and Agriculture Organization of the United Nations, 1979). Epicormic growth is illustrated in Figure 9.

Proventitious buds arise from accessory bud tissue and are also called dormant or epicormic buds (Penfold \& Willis, 1961). Epicormic buds are activated by various stimuli, including fire and drought, throughout the lifespan of the tree (Groom \& Lamont, 2015). The primary function of epicormic regrowth is rapid crown reestablishment, however strong stems from lignotubers also restore seed bearing potential in environments where species survival is limited by seedling recruitment (Groom \& Lamont, 2011). New shoots develop from thousands of dormant epicormic buds on 
the trunk and branches (Food and Agriculture Organization of the United Nations, 1979). Shoots from these buds are called reversion, proventitious or epicormic shoots (Food and Agriculture Organization of the United Nations, 1979; Penfold \& Willis, 1961). As eucalypt stems and branches grow in diameter and shed leaves, small shafts of tissue (proventitious bud strands) grow outward radially from the accessory tissue pads at the base of naked buds (Food and Agriculture Organization of the United Nations, 1979; Jacobs, 1955; Penfold \& Willis, 1961). Proventitious bud strands are capable of producing new, leafy proventitious shoots but are normally inhibited by hormones produced in the healthy crown or branch ends above (Food and Agriculture Organization of the United Nations, 1979; Penfold \& Willis, 1961).

Dormant buds are also important for maintaining eucalypt crown development. When primary branches reach extension limits, proventitious shoots continue branch extension (Penfold \& Willis, 1961). Additionally, epicormic shoots repair branches and crowns even when they are not damaged (Food and Agriculture Organization of the United Nations, 1979). While most apparent on damaged trees, epicormic shoots also enable large trees to reestablish crowns when branches become too long and mechanically unstable. Epicormic shoots develop back along the branch in safety from instability and unstable branch ends die off (Food and Agriculture Organization of the United Nations, 1979).

Eucalyptus globulus responds to injury by vigorously sprouting from the base, trunk, and underground root system (National Park Service, 2002). Vegetative regeneration is adaptive under stressful conditions because it rapidly replaces carbohydrate manufacturing plant tissues. Both presence and prevalence of vegetative regeneration 


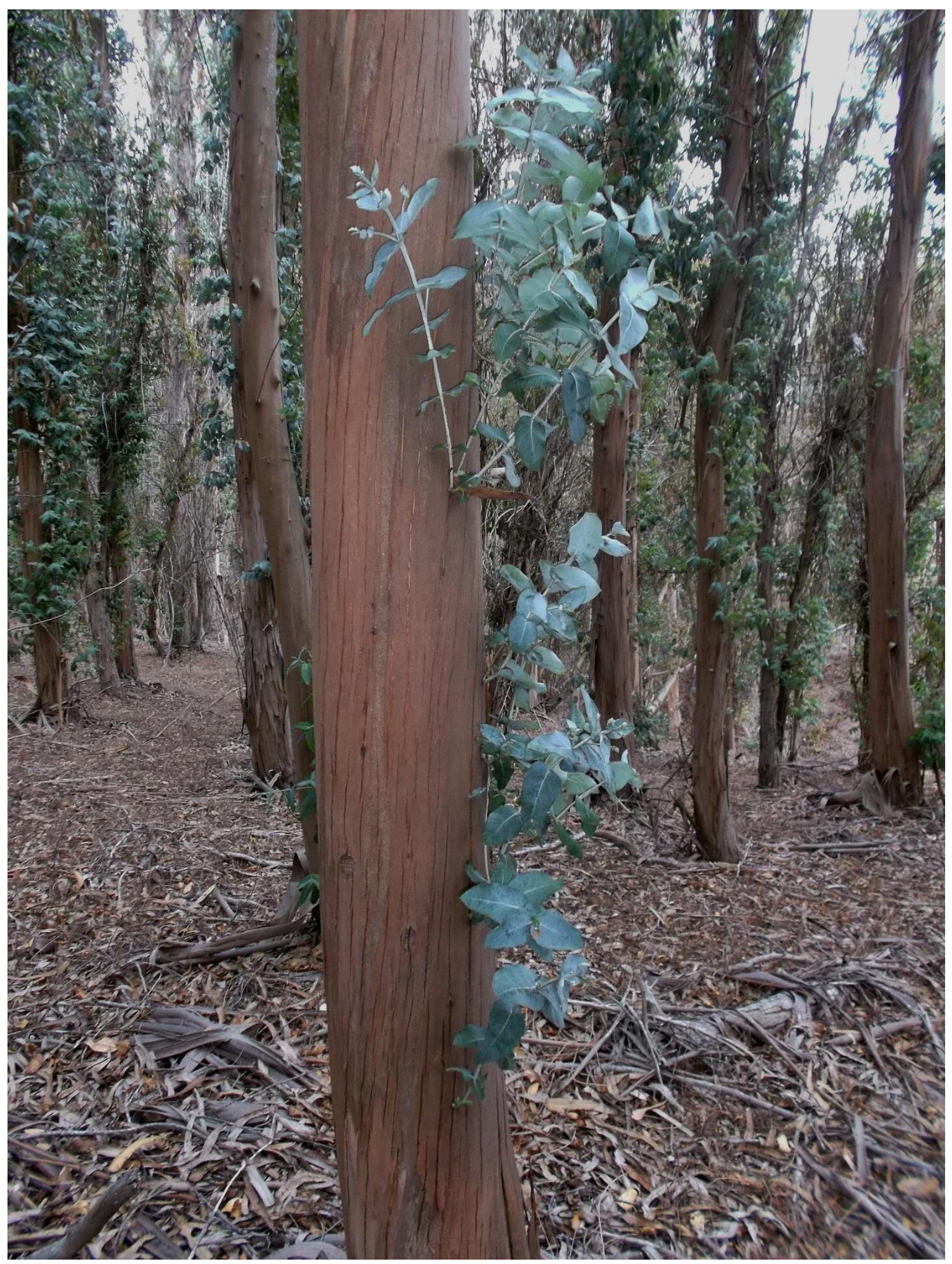

Figure 8. Epicormic growth. Montaña de Oro State Park, Los Osos, Ca. November 27, 2015. 
may influence species composition and succession (James, 1984). Hanes (1971)

concluded that fire selects for vegetative characteristics aiding in survival and described vegetative survival and succession patterns after fire using the terms "self-replacing vegetation" and "autosuccession." Sprouting prevents elimination, and sprouters maintain dominant position after fire (Hanes, 1971). There is no substantial competition for space because sprouters remain established and are adapted to frequent, widespread fire (James, 1984). Sprouters use stored carbohydrate and water resources for growth without optimal environmental conditions (Specht \& Rayson, 1957). Also, sprouters deep root system may reach deeper water tables (James, 1984).

The lignotuber is a woody swelling at the stem base/root crown containing dormant buds, carbohydrates, and nutrients necessary for bud development (Figure 8) (James, 1984; Rejmánek \& Richardson, 2011). Lignotubers are modified stems and extremely significant because of their underground storage of living buds (Penfold \& Willis, 1961). Carrodus and Blake (1970) found limited carbohydrates in eucalypt lignotubers and therefore identified the protected, concealed bud storage as the selective advantage (biological benefit) in lignotuber development (biological cost). Lignotubers are specialized for sprouting and enable the renewal of the above ground portions of the tree is destroyed (James, 1984; Penfold \& Willis, 1961).

The lignotuber originates as two swellings in the axils of the cotyledons during the seedling's first year. Eventually, the pair of swellings fuse together and increase in size. The axillary hemispherical mass is a vegetative propagule known as a lignotuber and is a regeneration organ. The lignotuber grows down the stem and is buried in the soil until it is only partially visible or totally underground. Dormant buds become active and 


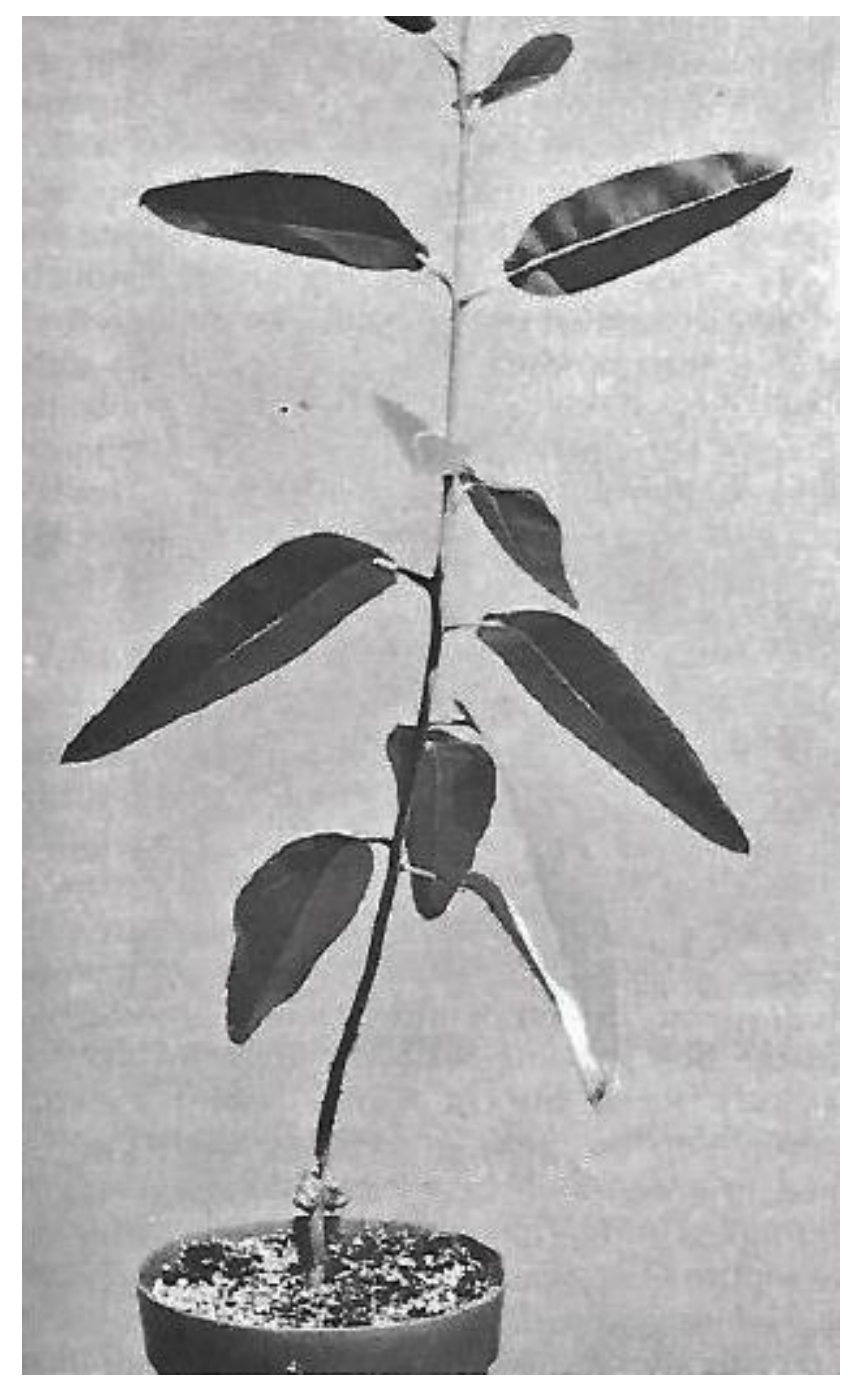

Figure 9. Exposed lignotuber (Pryor, 1976).

produce shoots bearing juvenile foliage if the tree is cut down. The lignotuber then enlarges, and the new shoots are stronger. One shoot normally dominates and becomes the new main stem (Penfold \& Willis, 1961). Lignotubers also enable eucalypt seedling survival during unfavorable periods until root systems become established. Lignotuber occurrence in eucalypts depends on climatic conditions because eucalypts develop lignotubers when the first leaves develop during severe drought (Kerr, 1925).

Gill (1977) distinguished vegetative survival through bud protection and resprouting 
as one of four major fire adaptive traits. Lignotubers below the soil surface are insulated from intense surface temperatures (James, 1984). High soil temperatures are confined to shallow depths (Priestley, 1959). Lignotubers enhance sprouting potential for sprouters regenerating through root, stem, or crown sprouting (James, 1984). Eucalyptus globulus' lignotubers live for many years in the soil after stems die (Skolmen, 1983). Sprouting new stems or root tissue from a lignotuber after injury is one of the most significant modes of reproduction in Mediterranean-type ecosystems (James, 1984).

Serotiny (fire stimulated seed release) is another fire adaptation (Rejmánek \& Richardson, 2011; Ritter, 2012). Most seeds stay inside the fruit and are only released after fire (Rejmánek \& Richardson, 2011). Heat resistant capsules protect seeds, and accelerated seed shed occurs after fire (National Park Service, 2002). Some seed may be shed yearly, but shoot death triggers dehiscence (Gill, 1977). Seeds otherwise shed sporadically when fruit falls from dead branchlets are induced to rain from ripe capsules by hot fire (Pryor, 1976). Dehiscence (when the capsule opens and sheds seed) may depend on fire severity, and two or more years seed may be shed upon crown death (Gill, 1977). Fire may release eucalypt seed normally shed enclosed in capsules, and the dispersal period may also be decreased (Gill, 1981). Eucalyptus globulus takes advantage of fresh, exposed soil available and competition reduction after fire (Gill, 1981; Pryor, 1976). On-plant stored seed release after fire is considered a fire adaptive trait because it enhances fitness in relation to fire (Gill, 1977; Gill, 1981). Species may have more establishment success when many individuals are introduced at once or repeatedly because it may help ensure mating, offspring production, and sufficient 
genetic variation for coping with environmental variability (Randall \& Hoshovsky, 2000).

Resprouting and serotiny are adaptive traits in fire-prone environments. Adaptive traits provide fitness advantages in given environments. Fire-adaptive traits originated in response to fire. Plants are adapted to specific fire regimes, and species adapted to particular fire regimes can be threatened by fire frequency changes. Serotiny is tied to crown fire regimes, and there is relatively little successful seedling recruitment without fire. The close association between fire-prone environments and resprouting from lignotubers suggests the trait is a fire adaptation. Eucalypts resprout epicormically after high-intensity crown fires in Australian forests and replace the canopy within a year (Keeley, Pausas, Rundel, Bond, \& Bradstock, 2011). Apical dominance is removed, and dormant buds develop after injury or destruction of the aerial portion of the plant (James, 1984). Reducing tree density induces sprouting that may spread fire from the surface to tree crowns (Ashton, 1981). Sprouting is particularly common in Mediterranean climates due to frequent fire disturbances (Keeley, 1981).

Fire has been a factor throughout the evolution of land plants and has shaped plant traits (Keeley et al., 2011). Fire burns extensive dry, sclerophyll forest areas every 3-5 years in Australia and nearly all native dry, sclerophyll forest areas once every 20 years since aboriginal occupation (Pryor, 1976). Specialized epicormic resprouting originated in eucalypts at least 60 million years ago (Crisp, Burrows, Cook, Thornhill, \& Bowman, 2011). Fire's evolutionary pressure selected traits that confer survival and/or reproductive advantages. In fire prone environments, these traits are adaptive and provide resilience to specific fire regimes (Keeley et al.). 
Crisp, Burrows, Cook, Thornhill, and Bowman (2011) showed a significant link between epicormic resprouting in Myrtaceae and flammable biome evolution. Unlike other continents, a single plant family, Myrataceae, dominates Australian fire-dependent woodlands and forests (Crisp et al., 2011; Ladiges et. al, 2003). Australia's tree flora is dominated by a single genus, Eucalyptus, and related Myrtaceae. Fire-dependent biomes cover most of Australia, so fire tolerance likely caused the dominance (Crisp et al., 2011).

Fire frequency, fire intensity, and season of burn are the components of a fire regime (Gill, 1973). Vegetation structure is largely determined by fire frequency, and vegetation structure largely determines fire intensity (Keeley, 1981). Fire is a unique environmental factor because it depends on vegetation for its occurrence, requires a trigger, and tends to self-propagate after ignition. Fire may profoundly effect standing plant biomass, although exposure time is very brief (Gill, 1973).

Eucalyptus globulus alters fire regime because fuel loads are significantly greater in E. globulus groves versus native oak woodland. Eucalyptus globulus were mostly planted in California grasslands, and grassland wildfire is typically more frequent but less intense than wildfire in heavily wooded areas. High intensity fire can also impact soils and seed bank mortality. Impacts can be significant where E. globulus grows in high densities under favorable conditions (California Invasive Plant Council, 2015a).

Plants are adapted to particular fire regimes, and different fire regimes select for very different plant traits. Adaptive traits provide resilience to specific fire regimes in fireprone environments (Keeley et al., 2011). Resilience to minimum and maximum intervals without fire may be critical for species survival (Keeley, 1981). However, species exhibiting fire adaptive traits can be threatened by fire regime changes (Keeley et 
al.). Changes in fire frequency, severity, or seasonality can limit post-fire survival and regeneration ability of species adapted to particular fire regimes. Biological benefits become debts when adaptations to particular fire regimes limit fitness by rendering inability for adaptation to fire frequency, severity, or seasonality change (Keeley et al., 2009).

Reproductive strategies and tactics have partially evolved in response to both disturbance frequency and severity (James, 1984). Reproductive strategy describes energy allocation associated with reproduction (Harper \& Ogden, 1970). Reproductive effort and energy allocation are tactical options within each strategy. Reproductive effort is estimated by the biological cost of reproduction (James, 1984). Calow (1979) measured the cost of reproduction in terms of nutrients required for plant metabolism alternatively used for gamete production. Each strategic or tactical developmental response represents an allocation of limited time or energy (Cody, 1966; Harper \& Ogden, 1970). Resources necessary for maintenance increases with growth, but growth may also increase resource acquiring ability (Gadgil \& Bossert, 1970). Reproductive strategy must complement biomass production strategy and perennating organ maintenance (James, 1984). A genotypic program may include a range of developmental paths, each determined by different environmental conditions (Harper \& Ogden, 1970; Lovett Doust, 1980). The outcome of genotypic strategy and tactical environmental responses is life cycle expression (phenotypic ontogeny) (Harper \& Ogden, 1970).

Keeley and Zedler (1978) identified three basic life features related to reproductive success and fire: (1) ability to survive fire (2) ability to establish seedlings after fire (3) longevity and competitive ability between fires. Available nutrients, predation resistance, 
and extreme climate vulnerability affect individual persistence between fires (James, 1984). Keeley (as cited in James, 1984) hypothesized root depth, adventitious bud location, stored carbohydrates, plant water status, individual size, recovery between fires, fuel loading, and fire behavior are important factors associated with fire resistance (Keeley \& Zedler, 1978).

Every plant characteristic has an associated cost. The characteristic is a biological debt in an environment where it does not contribute to fitness (Steinmaus, 2002e). The biological cost associated with resource allocation for lignotuber production is merited in fire prone areas where the lignotuber is a biological benefit ensuring survival after stems die. James (1984) associated the evolution of lignotubers with fire or drought prone areas, since they are most often found in Mediterranean-type climates. The vascular system continuity between buds and roots is important for fire survival. Many woody plants survive above-ground fire by burying buds in soil (Gill, 1981). Subterranean positioning is valuable for vegetative survival because soil is a very effective insulator (Gill, 1981; Priestley, 1959). Most heat rises during fire, and only a small proportion penetrates the soil (Gill, 1981; Packham, 1971). Depth below the soil surface is important for reproductive organ protection during fire (Flinn \& Wein, 1977).

Eucalyptus globulus is well adapted to frequent fire regimes. Epicormic buds sprout new branches from stems after fire or severe winter (Rejmánek \& Richardson, 2011). Epicormic bud forming structures present in the outer bark in most angiosperm trees are present at the vascular cambium level in eucalypts and protected by maximum bark thickness. Eucalypt epicormic structures appear unique among angiosperm tree species because they consist of narrow, continuous strips of cells of meristematic appearance 
rather than buds or bud primordia (Burrows, 2002). The buds are released from inhibition and develop into shoots if foliage is killed (Gill, 1977).

Eucalypts are sometimes considered destroyed after large, high-intensity fires kill tree crowns and stems, but vigorous epicormic and basal resprouting often keep individual death rates low (Bradstock, 2008; Gill, 1997; Nicolle, 2006). Some bark death and thickness reduction is usual during fires, but bark regrowth may occur if death is only partial and the interval between fires is long enough. Restoration will begin within the remaining live inner bark and dead outer bark abscised (Gill, 1980).

Damage sustained by trees during fire may largely depend on intensity and duration. Low intensity fires may only affect small portions of the tree trunk, and leave the crown undamaged. Bark death may be to cambium level among crown branching but superficial on the trunk with high intensity fires. Subsequent bark recovery after fire is important for future fire protection, and the extent of bark regrowth may determine shoot survival during the next fire (Gill, 1980). Bark thickness generally increases with trunk diameter, so fire damage susceptibility is greatest in young trees (Ashton, 1981).

Invasive plants traits can be divided into three components for risk assessment: undesirability, biogeographical, and biological. Traits causing allergies, toxicity, or physical harm are undesirable. The biogeographical component refers to the invaded site's climatic suitability (Steinmaus, 2007). Similar climates offer a wide range of novel organisms for potential introduction (White, 1997). Plant species' invasiveness in invaded areas is significantly positively correlated with native geographic ranges. Plant species with wide geographic distributions are typically abundant and form dominant populations (Williamson \& Fitter, 1996). "It is thought that species with large native 


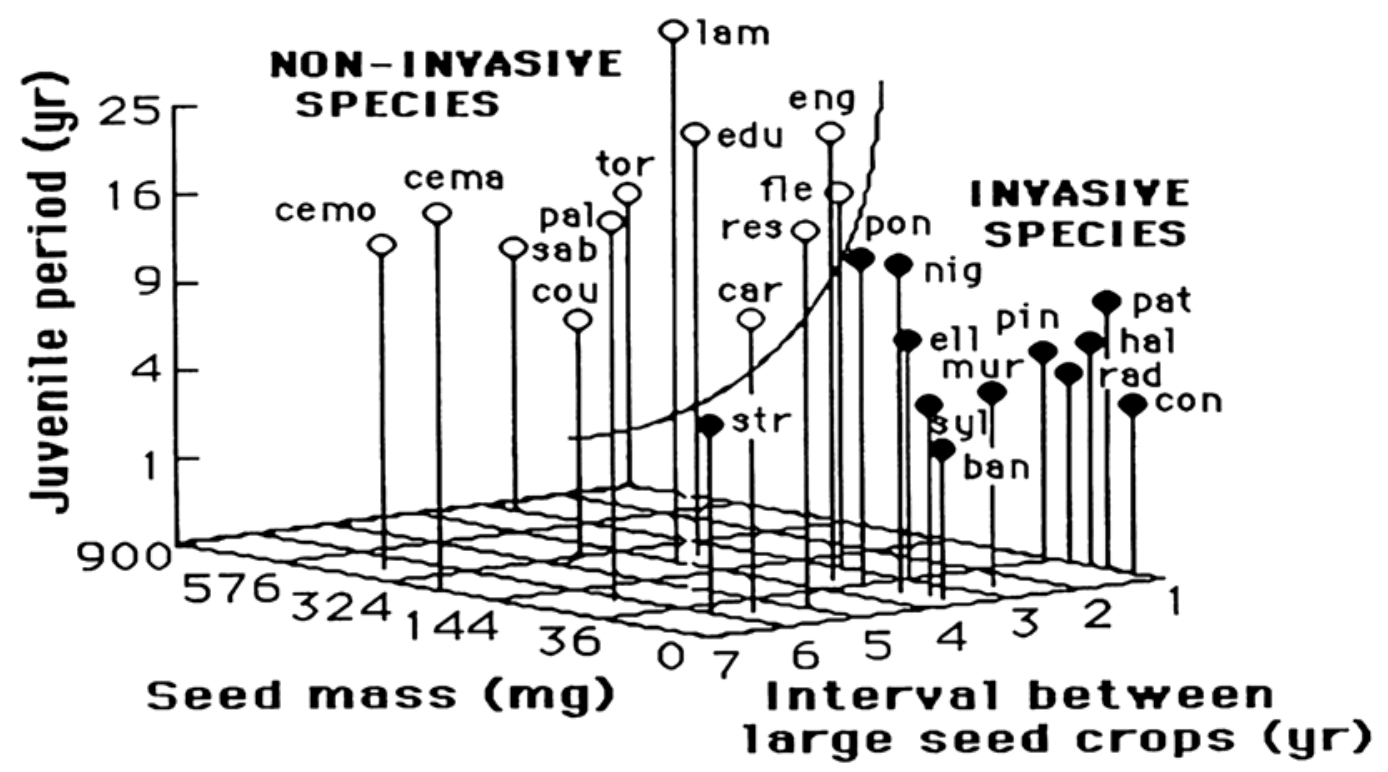

Figure 10. Distribution of 24 frequently cultivated pine species (abbreviated) in a space created by three biological variables separating invasive and non-invasive species

(Rejmánek \& Richardson, 1996).

ranges are adapted to a variety of climate and soil conditions and are more likely to find suitable habitat in a new area" (Randall \& Hoshovsky, 2000).

The biological component addresses traits contributing to invasiveness (Steinmaus, 2007). Rejmánek and Richardson (1996) found short juvenile periods, short intervals between large seed crops, and small seed mass are three invasiveness predictors (Figure 10). Both short juvenile periods and short intervals between large seed crops facilitate early, consistent reproduction and rapid population growth (Rejmánek \& Richardson, 1996). Small seed mass facilitates elevated seed production, dispersal, high germination rates, and faster relative seedling growth rates (Rydin \& Borgegard, 1991; Grime, Hodgson, \& Hunt, 1988; Maranon \& Grubb, 1993). Chances one randomly scattered 
seed will land on an appropriate site increases with increased seed dispersal if appropriate sites are limited (Randall \& Hoshovsky, 2000).

The consensus invasive plant trait list for governmental agencies includes small seed size, short juvenile period, low nuclear DNA content, short interval between large seed sets, few seed dormancy breaking requirements, and rapid vegetative spread and propagation (Steinmaus, 2007). Cells with low DNA content can divide and multiply quickly and consequently grow faster (Rejmánek, 1996). Genome size and mitotic cycle duration have a very close relationship in plants (Bachmann, Chambers, \& Price, 1985). Bennett (1987) concludes there is a relationship between nuclear DNA content and minimum generation time in higher plants. More specifically, Rejmánek (1996) suggests species with low nuclear DNA content are more likely to invade disturbed habitats. Rapid germination and growth facilitates successful competition after disturbance through niche (space) occupation and species exclusion (Randall \& Hoshovsky, 2000). Few seed dormancy breaking requirements enable easy germination in a variety of environments (Steinmaus, 2007). Exotic plants encountering species in the same genus in invaded areas will share many common traits and must compete with those similar species already in place (Darwin, 1859). Reichard (1997) also suggests plant species capable of both seed and vegetative reproduction are better invaders in new areas. Eucalyptus globulus uses both reproductive strategies and has no seed dormancy (Rejmánek \& Richardson, 2011).

Callaway and Ridenour (2004) proposed that selection pressure may cause a rapid increase in competitive trait evolution and some invaders possess biochemical weapons native species have never encountered. Growth of many herbaceous plants is prevented 
by water soluble phytotoxins produced in E. globulus leaves (del Moral \& Muller, 1969). Phytotoxins exuded through leaf surface pores are transferred by condensation, fog drip, and rain, and create a ring around the tree base (Bean \& Russo, 1986). Rain also leaches toxic phenolic acids from eucalypt leaf litter (del Moral \& Muller, 1969). Allelopathy may be worse with low rainfall (Lange \& Reynolds, 1981).

The novel weapons hypothesis (NWH) proposes that exotic species add unique biochemicals to invaded regions and gain competitive advantage because the new neighbors are not adapted to these phytotoxic chemicals. Selection pressure for traits conferring competitive or defense advantages is greater on genotypes in the invaded regions than on native genotypes. This hypothesis, called the 'allelopathic advantage against resident species'(AARS), predicts that invasive populations will be more allelopathic or better biochemically defended than source populations (Bais, Vepachedu, Gilroy, Callaway, \& Vivanco, 2003; Callaway \& Aschehoug, 2000; Callaway \& Ridenour, 2004; Cappuccino \& Arnason, 2006; Vivanco, Bais, Stermitz, Thelen, \& Callaway, 2004;).

\section{Need for risk assessment and predicting potential range of invasive plants}

Determining potential invasive plant species and conditions allowing successful invasion influences landscape planning, conservation, and restoration efforts. Understanding whether conditions allow superior competition and corresponding native plant displacement or give weak opportunists the appropriate circumstances will help land managers prioritize management efforts most cost efficiently (Steinmaus et al., n.d.). For example, both disturbance associated with fire or soil water availability may constrain various eucalypts and therefore assist management decision prioritization 
(Liedloff \& Cook, 2007). Biological invasion is a natural process, but the current rate of invasion is clearly human related and one of the most important human effects on Earth's ecosystems. Therefore, tools are needed for potential invader prediction (Rejmánek, 1996).

Predicting the potential range of invasive plants is crucial for invasion prevention (Steinmaus, 2002c). Rejmánek (2000) listed prevention, exclusion, early detection, rapid assessment, control, containment, and eradication as the fundamental management objectives for invasive plants. The Animal and Plant Health Inspection Service (APHIS) is the USDA agency which prevents certain foreign pests from entering the United States. Regulatory strategies for non-indigenous weeds include prevention, preclearance, exclusion, detection, containment, eradication, and biological control (Westbrooks \& Eplee, 1996). The uncertainty and expense involved with detection, containment, eradication, and biological control switches focus to prevention, preclearance and exclusion (White \& Schwartz, 1998).

Key factors in prevention strategy are anticipation of species, sites, and possible disturbances facilitating invasion (Steinmaus, 2002c). Invasion prevention is the most effective and efficient weed management strategy. Identifying and predicting species most likely to invade helps direct management strategies for species, community, and ecosystem preservation (Randall \& Hoshovsky, 2000).

Steinmaus (2002b) identified the components of successful invasion: species characteristics, site characteristics, and disturbance:

(1) Species characteristics - the biological factors contributing to invasivity, also considering native weaknesses; 
(2) Site characteristics - the environmental factors, complexity, isolation, and transition areas between adjacent but different plant communities (ecotones);

(3) Disturbance - any change from native conditions facilitating invasion.

Biological characteristics used to predict invasiveness in Reichard's risk assessment system for woody plants in North America and the Australian weed risk assessment system for all plants use the following criteria (Reichard \& Hamilton, 1997; Pheloung, 1995):

(1) Invasive elsewhere,

(2) Biological relationship to species exhibiting invasive behavior (e.g. same genus),

(3) Climatic/ecological similarity between introduced area and native range,

(4) Aggressive traits (allelopathy or superior competitor), and

(5) Biological attributes including vegetative reproduction, vine-like growth habit, short juvenile period, habitat generalist, and easy germination/establishment.

Biological characteristics alone are often not enough for invasion prediction. The other two components of successful invasion, site characteristics and form of disturbance, also need consideration (Steinmaus, 2002b). Cronk and Fuller (1995) offer general hypotheses explaining plant invasions, and they can be used to identify sites with susceptible characteristics. Susceptibility is based on:

(1) Predator(s) absence,

(2) Poorly adapted natives with low reproductive vigor,

(3) Low site biodiversity, and

(4) Open ecological niches. 
Steinmaus (2002b) explained some extremely aggressive invaders establish and infest intact native habitat. However, most are opportunistic and favor anthropogenic disturbance. These disturbances include:

(1) Chemical (e.g. fertilizer, sewage, and nitrogen deposition),

(2) Physical (e.g. erosion, bare ground, roads and construction),

(3) Biological (e.g. niche plant removal), and

(4) Hydrologic (e.g. irrigation and groundwater pumping).

Modeling invasion will identify, quantify, and incorporate the most significant variables and develop the most useful prediction (Steinmaus, 2002b). Evidence of invasive potential through modeling allows priority management (Steinmaus, 2002c). Highest priority should be assigned to preventing, quickly detecting, and eliminating new invasions. High priority goes to species with the most damaging impacts, rapidly expanding infestations, and infestations affecting highly valued areas. Also, predicting control difficulty determines management strategy resource allocation (Randall \& Hoshovsky, 2000).

Predicting areas prone to invasion is also essential for invasion prevention (Steinmaus; 2001; Steinmaus, 2002b; Steinmaus, 2002c). Areas where humans or animals have disturbed the vegetation and soil are more susceptible. Plants adapted to agricultural disturbances commonly invade disturbed sites. Climatic match between native and potential invaded areas also influences invasion susceptibility. Plant species with large native ranges are believed more likely to find suitable new habitat because of their adaptation to variable climate and soil conditions (Randall \& Hoshovsky, 2000).

History, migration, trans-continental travel, and settlement in new areas likely also 
played a large role in determining the susceptibility of a site to invasion. Seaports, railroad terminals, and military supply depots are all highly exposed. Migrating people also introduce plants from their homelands. For example, European colonists brought familiar, exploitable plants and animals. In fact, Europeans and European plants and animals colonizing the Americas, Australia, and other areas of the world may correlate with one successful species promoting the success of others. The plants and animals benefited from cleared native vegetation and plowed soil (Randall \& Hoshovsky, 2000). The worst invasive species, presumably because of release from native management factors, are the result of intercontinental introduction (White \& Schwartz, 1998).

Identification is the first defensive tactic for establishment prevention and impact management. An illustrated identification guide informs the public sector and those interested in preventing invasive species establishment and managing their impact. Weed Management Areas (WMA) bring together landowners and managers (private, city, county, State, and Federal) in a county or geographical area and organize efforts against invasive and noxious weed species. Mutually developed "memorandum of understanding" (MOU) describes the purpose and role of the WMA and defines the role of federal, state, county, city, and private agencies and sectors in preventing introduction, establishment, and dispersal of invasive plant species. They develop strategies for monitoring, eradication, management, and containment projects for designated noxious and invasive plant species. The WMA exchanges information on current problems with established species, new information on potential invaders, and management progress. Research goals and funding priorities are also developed (Steinmaus, 2001). Weed management areas emphasize education and prevention, foster collaboration between 
public and private sectors, and are meant to complement the California Department of Food and Agriculture's (CDFA) weed management programs. They partner in statewide weed eradication programs but are organized locally and address local issues (California Department of Food and Agriculture, 2009).

Predictive models use mapping information and climatic preference to predict plant invasion. Models predict successful invasion so proper management strategy and education effort prioritization can be implemented (Steinmaus, 2002c). Biological characteristics do not consider site characteristics or disturbance (Steinmaus, 2002b, Steinmaus, 2002c). Models account for the multidimensional nature of ecological and biological systems. Steinmaus explains both scientists and land managers agree prevention, prediction, and control is the most effective management protocol. Education, predictive modeling, and population mapping are the key elements for this management strategy (Steinmaus, 2001). After all, it is better to prevent a weed problem than control one (Reichard \& Campbell, 1996).

Climatic modeling brings together the biological and abiotic factors regulating survival and growth (Sutherst, 2000). Modeling determines invasion success likelihood for management prioritization (Steinmaus, 2001). Predictive models help land managers focus management efforts by efficiently determining the factor or few factors truly driving invasion (Steinmaus, 2002c). Mapping is the foundation for constructing an invasive plant database. Characteristics of the areas successfully supporting E. globulus can then be collected and species preferences and constraints developed (Steinmaus, 2001). Biological comprehension identifies life stages susceptible to management and also identifies futile control methods (Steinmaus, 2002d). Management strategy can then 
efficiently focus on the weaknesses rather than strengths. Models including biotic and abiotic information in addition to climatic information will greatly improve predictive accuracy. Following populations over time gauges management strategy effectiveness, and the climatic, abiotic, and biotic information develops a bioecological comprehension of invasion (Steinmaus, 2001).

\section{Conclusion}

Minimizing the invasive plant threat motivates need for both predicting the potential range and preventing spread. Invasions directly threaten human life and property. Invasion costs millions of dollars in direct economic losses (Reichard \& Campbell, 1996). While the most important impact of invasion is native species displacement, invasive plants are also of anthropocentric significance because they interfere with land management objectives and/or agricultural production (Steinmaus, 2002e). Indirect threats include herbicide use, habitat manipulation, and biocontrol agent introduction (White \& Schwarz, 1998).

Eucalypts require adequate moisture to spread from planted locations, therefore the genus is not prone to global invasive spread (Rejmánek \& Richardson, 2011). In rare circumstances, eucalypts with adequate soil moisture can spread into neighboring plant communities by suckering or seed (Steinmaus et al., n.d.). Eucalyptus globulus receives enough moisture to propagate from seed on the California coast, and coastal groves are estimated to spread 10-20 feet in diameter/year. Inland California valleys do not receive adequate moisture for seed propagation. However, trees and groves cultivated for fuel, timber, and windbreaks there still release germination inhibiting phytotoxins (allelochemicals) that restrict species diversity directly underneath the crown (Bean \& 
Russo, 1986). Eucalyptus globulus is abundant in California, and its development and biology is conducive for coastal Californian ecosystem invasion (Steinmaus, 2007).

Eucalyptus globulus invasion threatens ecosystem biodiversity by displacing native species and altering ecosystem hydrology, fire regimes, and soil chemistry (Boyd, 2000; Randall \& Hoshovsky, 2000). The long term survival of E. globulus in California depends on landscape preference (for successful regeneration) and landscaping practices. Predicting its potential range is vital for management (Steinmaus et al., n.d.). Assessment of the possible reach and spread of E. globulus directs control, containment, and eradication decisions (Steinmaus, 2001; Steinmaus et al., n.d.). Control costs increase exponentially over time with increasing infestations, so prevention, early detection, and rapid response are important investments for California (California Invasive Plant Council, 2015b).

Removing established, invasive eucalypt populations is especially difficult partly because they are interspersed in both human habitation and sensitive habitat. Persistent vegetative regeneration from lignotubers necessitates removing the majority of the root system. Furthermore, desirable groves would potentially be damaged by biocontrol agents (Steinmaus et al, n.d.).

Eucalyptus globulus possesses well adapted characteristics for invading coastal California ecosystems but seems to require anthropogenic soil disturbance (Steinmaus, 2007). Disturbance, including altered fire frequency and intensity, altered hydrologic cycles, altered soil cover or chemistry, reduced light penetration, and altered vegetation structure, can potentially crucially tip threatened species towards either extinction or 
survival. Eucalypts thrive in biodiversity hotspots where disturbance further endangers threatened species (Steinmaus et al., n.d.).

Fire does not kill E. globulus. Rather, it uses fire's cue for mass seed drop when competitors are removed. Eucalyptus globulus promotes fire with combustible oil, flammable litter, and draping bark capable of spreading fire to crowns (ribbony). Persistent vegetative sprouting quickly regenerates the tree after fire, injury, or removal. Eucalyptus globulus explodes into flames when fuel below burns intense enough to ignite crown foliage. Eucalyptus globulus's litter accumulates quickly, increases site fuel loads, and consequently increases fire intensity (Williams, 2002).

Cutting eucalypt trees but not totally removing them allows regrowth and results in dead debris suspended between trees and/or understory and a low branch height both horizontally and vertically. Eucalyptus globulus coppices (regrows from trimming) easily, and stems growing from stumps after felling result in bush-like growth (Figure 11) (Boyd, 2000). This continuous arrangement of fuel provides a ladder for fire and equates to near certain torching and crown fire (Ashton, 1981; Rice, n.d.).

Education, predictive models, and mapping are the key factors for successful $E$. globulus management. Weed management areas bring together private, state, and federal sectors to combat the introduction and establishment of noxious and invasive plant species. Predictive models based primarily on climatic parameters and presence predicts sites susceptible to invasion for the proper preemptive management strategy. Population mapping tracks successful invaders and identifies locations for management practices. Identifying invaded locations is the first step in a management program for established species (Steinmaus, 2001). 


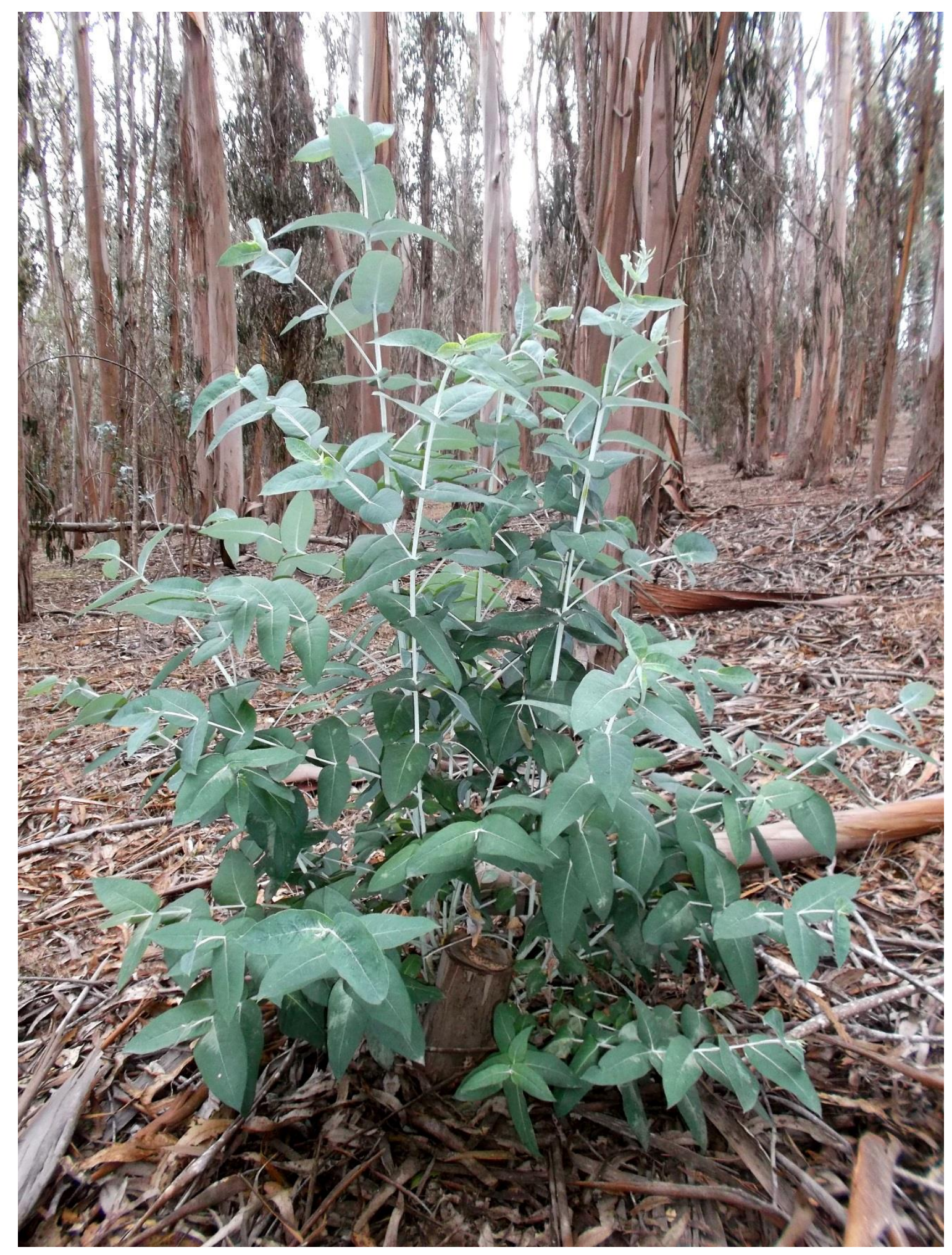

Figure 11. Stump sprouting. Montaña de Oro State Park, Los Osos, Ca. November 27, 2015. 


\section{Chapter 3}

\section{Materials and Methods}

Climate is the most important factor for invasive potential evaluation because plants will not survive if they cannot tolerate a new location's climate, regardless of other limiting factors (Steinmaus, 2002c). The climatic matching simulation, Climex, will model and predict the potential range of E. globulus in California. Climex matches species response to temperature, moisture and photoperiod with the temperature, moisture, and photoperiod of a location being tested.

Climex determines an overall climatic suitability (Ecoclimatic Index) for E. globulus at locations in California. Climex contains meteorological data for 14 locations in California. Dr. Steinmaus formatted a National Oceanic and Atmospheric Administration (NOAA) database, increasing the total to 321 locations in California, thus immensely enhancing prediction.

The Ecoclimatic Index (EI) is a product of the Growth Index (GI) and Stress Index (SI). The GI is the growth potential at a location based on temperature and moisture preferences. Temperature, moisture, diapause, and light thresholds determine Growth Index (species abundance). The SI shows death potential at a location based on stress accumulation. Cold, heat, dry, and wet stress determine Stress Index (species distribution).

Climex uses the biological information for E. globulus, fits it into a built in climatic template, and builds a predicted native distribution map. The climatic parameters from the template's observed native distribution are then fit to match the true native distribution. The model is then applied to California and determines climatic suitability 


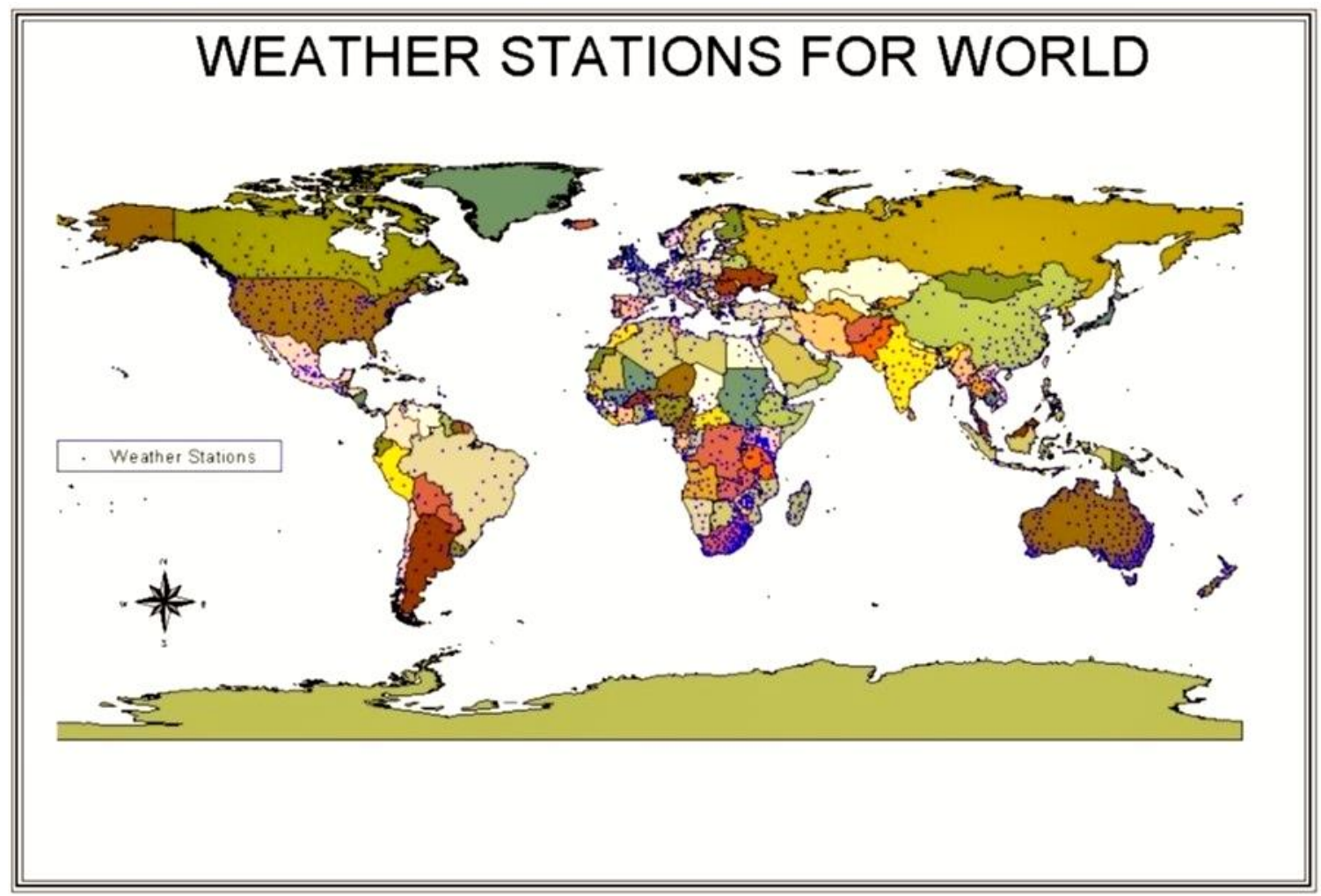

Figure 12. Climex software comes with a meteorological database that represents 2031 locations around the world and 14 for California (Steinmaus, 2002c).

for E. globulus in California. The Climex model is parameterized using meteorological data from 319 locations in California.

Climex comes standard with a meteorological database that covers 2031 locations around the world including 14 California locations (Figure 12). In order to develop a sufficiently fine resolution for predicting spread in California, Dr. Steinmaus and I had to enhance the meteorological database in Climex with more California locations. We obtained data from the U.S. Department of Commerce National Oceanic Atmospheric Administration's (NOAA) website and subsequently reformatted for use in Climex using the macro generating tools available in Excel. The NOAA database did not provide relative humidity values which are required input for Climex. Relative humidity refers to 
the value of vapor pressure (VP) relative to saturated vapor pressure $\left(\mathrm{VP}_{\text {sat }}\right)$ or water vapor relative to the air temperature. Relative Humidity is provided by the equation:

$$
\mathrm{RH}=\mathrm{VP} / \mathrm{VP}_{\text {sat }} * 100
$$

Vapor pressure at each climate station was provided by the Daymet U.S. Data Center. Daymet is a model that generates daily surfaces of temperature, precipitation, humidity and radiation over large regions of complex terrain using a raster grid (Kimball, Running, \& Nemani, 1997; Thornton, Running, \& White, 1997; Thornton \& Running, 1999; Thornton, Hasenauer, \& White, 2000). It was developed to provide fine resolution, daily climatological and meteorological data for plant growth model inputs. Data is provided as a continuous surface of the conterminous United States at a $1 \mathrm{~km}$ resolution. This data is distributed from the Numerical Terradynamic Simulation Group (NTSG) at the University of Montana. Data were presented as the 18-year (1980-1997) mean of the monthly vapor pressure values. Data is available as binary (floating point) grids. They were imported into Arcview 9.10 as raster grids using the spatial analyst extension. Point data for climate station locations were then overlaid and corresponding raster grid values were extracted. These vapor pressure values were incorporated into equation 1 . Next, Saturated Vapor Pressure, $\mathrm{VP}_{\text {sat }}(\mathrm{T})$, in $(\mathrm{Pa})$ at temperature $\mathrm{T}$ (degrees $\mathrm{C}$ ) for eq. 1, was estimated using the Murray formulation (Murray 1967):

$$
V P_{\text {sat }}(T)=610.78 \exp \left[\frac{17.269 T}{237.3+T}\right]
$$

Climex requires relative humidity values at two specific times of the day (9:00 and 15:00 hours). The corresponding temperature values (T) for eq. 2 at these two times were 
derived from the equation:

$$
\begin{gathered}
\mathrm{T}_{\mathrm{t}}=-0.32815+0.96592 \mathrm{~T}_{\mathrm{avg}}-\mathrm{W}-\mathrm{X}+\mathrm{Y}+\mathrm{Z} \\
\mathrm{W}=0.43503 \mathrm{~T}_{\text {range }} \cos \left(\mathrm{pi}^{*} \mathrm{t} / 12\right) \\
\mathrm{X}=0.14453 \mathrm{~T}_{\text {range }} \sin \left(\mathrm{pi}^{* \mathrm{t} / 12)}\right. \\
\mathrm{Y}=0.09995 \mathrm{~T}_{\text {range }} \cos (\mathrm{pi} * \mathrm{t}) / 6 \\
\mathrm{Z}=0.0245 \mathrm{~T}_{\text {avg }} \sin \left(\mathrm{pi}^{*} \mathrm{t} / 6\right)
\end{gathered}
$$

where $\left(T_{t}\right)$ is the predicted surface temperature at any time $t$ (i.e. local time), $T_{\text {avg }}$ is the daily mean temperature (degrees $\mathrm{C}$ ), and $\mathrm{T}_{\text {range }}$ is the daily range of temperature (degrees C) (McCutchan, 1979). This equation requires values for maximum and minimum temperatures as input. These values were provided by actual mean monthly maximum and minimum temperatures provided by the 319 weather stations used. These humidity values were then added to the new Climex database. Two files were created: a .met file with the meteorological data for each site plus a .loc file that contains the location data for each of the weather stations. These files were subsequently imported into Climex's meteorological database using the programs met manager function. Climex's map manager feature was then used to create a corresponding map for the new dataset. As a result, we were able to completely format a database adding a total of 319 locations for California, thus enhancing the resolution of prediction immensely.

Climate parameters are unknown, so parameters are adjusted to closely fit the known native distribution. Eucalyptus globulus occurs naturally in Tasmania, coastal South Victoria, and the islands between in Bass Strait, temperate climates with 500-1500mm of rain/year (Food and Agriculture Organization of the United Nations, 1979). California's rainfall is similar and fog drip compensates for rain while contributing to the success of E. globulus in California (Skolmen \& Ledig, 1990). The stature of E. globulus in 
combination with the shape and structure of its leaves allows efficient fog interception (del Moral \& Muller, 1969). Coastal California trees can intercept 289-605mm of water from fog/year (Dawson, 1998). This was modeled using the irrigation scenario, which allows water application. Climex allows users to consider potential climate change or irrigation implications on species abundance and distribution.

A second model using the maximum entropy method (Maxent) will predict geographic distribution of E. globulus in California. Maxent uses species' areas of occurrence and environmental variables influencing the suitability of the environment for E. globulus. Occurrence is tracked using latitudes and longitudes from areas where $E$. globulus is observed. Environmental variables for California are used to predict environmental suitability for E. globulus.

The best approach when approximating an unknown probability distribution is ensuring the approximation satisfies unknown distribution constraints, and the distribution should have maximum entropy subject to those constraints (Jaynes, 1957). Entropy measures dispersal and the outcome uncertainty involved for known event occurrence probability (Shannon, 1948). Therefore, a probability distribution maximizing entropy subject to the incomplete information constraints justifies using the distribution for inference. The distribution agrees with everything known and avoids assuming anything unknown (Jaynes, 1957).

Maxent originates from statistical mechanics and makes predictions or inferences from incomplete information (Jaynes, 1957). It is a general purpose and flexible statistical method suitable for application to all presence-only datasets and requires only presence data and environmental information (Phillips, Anderson, \& Schapire, 2006). 
Maxent produces a probability distribution model, respecting occurrence data constraints. The constraints are derived from environmental variable functions called features (Phillips \& Dudík, 2008). Maxent finds the optimal (maximum entropy) probability distribution using deterministic algorithms and estimates a target population probability distribution (Phillips et al., 2006). Here it is used for presence only E. globulus California distribution modeling.

Data for species geographic distribution modeling typically consists of geographic coordinates where the species is observed plus additional data measuring different environmental variables across the geographic region (Phillips, Dudík, \& Schapire, 2004). The goal is predicting areas matching the species' ecological niche requirements, thus partially forming its potential distribution (Anderson \& Martinez-Meyer, 2004; Phillips et al., 2006). The potential species distribution describes suitable survival conditions and is therefore greatly important for conservation biology (Phillips et al., 2004). The model predicts environmental suitability using presence only data and environmental data describing factors likely influencing suitability (Phillips et al.).

Maxent predicts suitability for E. globulus in California and has four possible occurrence probability predictions (Figure 13). First, a true positive predicts presence where E. globulus really is present. Second, a false positive predicts presence, but $E$. globulus really cannot grow at the location. Third, a false negative predicts absence, but E. globulus really can grow at the location. Lastly, a true absence predicts no occurrence where E. globulus really is absent. Maxent cannot distinguish if data absence is true absence, since it uses presence only data. It cannot tell where E. globulus would successfully grow but simply has not reached the location (S. Steinmaus, personal 
communication, November 18, 2014). Maxent uses a sample set from a distribution over some space and a feature set from the space. Occurrence localities are the sample points for species distribution modeling, the geographical region is the space defining the distribution, and the environmental variables are the features (Phillips et al., 2004). Maxent generates a probability distribution and repeatedly improves the fit to data starting from uniform distribution. Phillips (2005) defined gain as the presence samples average log probablity minus a constant that makes the uniform distribution have zero. The gain indicates the model's concentration around the presence data and is closely related to deviance (Phillips, 2005).

Maxent model values are output in raw, cumulative, and logistic formats. The raw output is the exponential model itself (Phillips, 2005). Maxent's primary output is raw probabilities, but the raw values are converted into an easier interpretable and usable cumulative format (Phillips et al., 2006). Predicted omission rate best interprets cumulative output (Phillips, 2005). The omission rate is the fraction of test localities not predicted suitable (Phillips et al.). The resulting binary cumulative threshold prediction contains a Maxent sample distribution omission rate and can predict a similar species distribution omission rate. Logistic output estimates presence probability between zero and one. The logistic value corresponding to raw value is a logistic function because the raw value is an environmental variable exponential function if the cumulative threshold is the distribution entropy exponential (Phillips, 2005). The E. globulus model picture uses logistic format. 


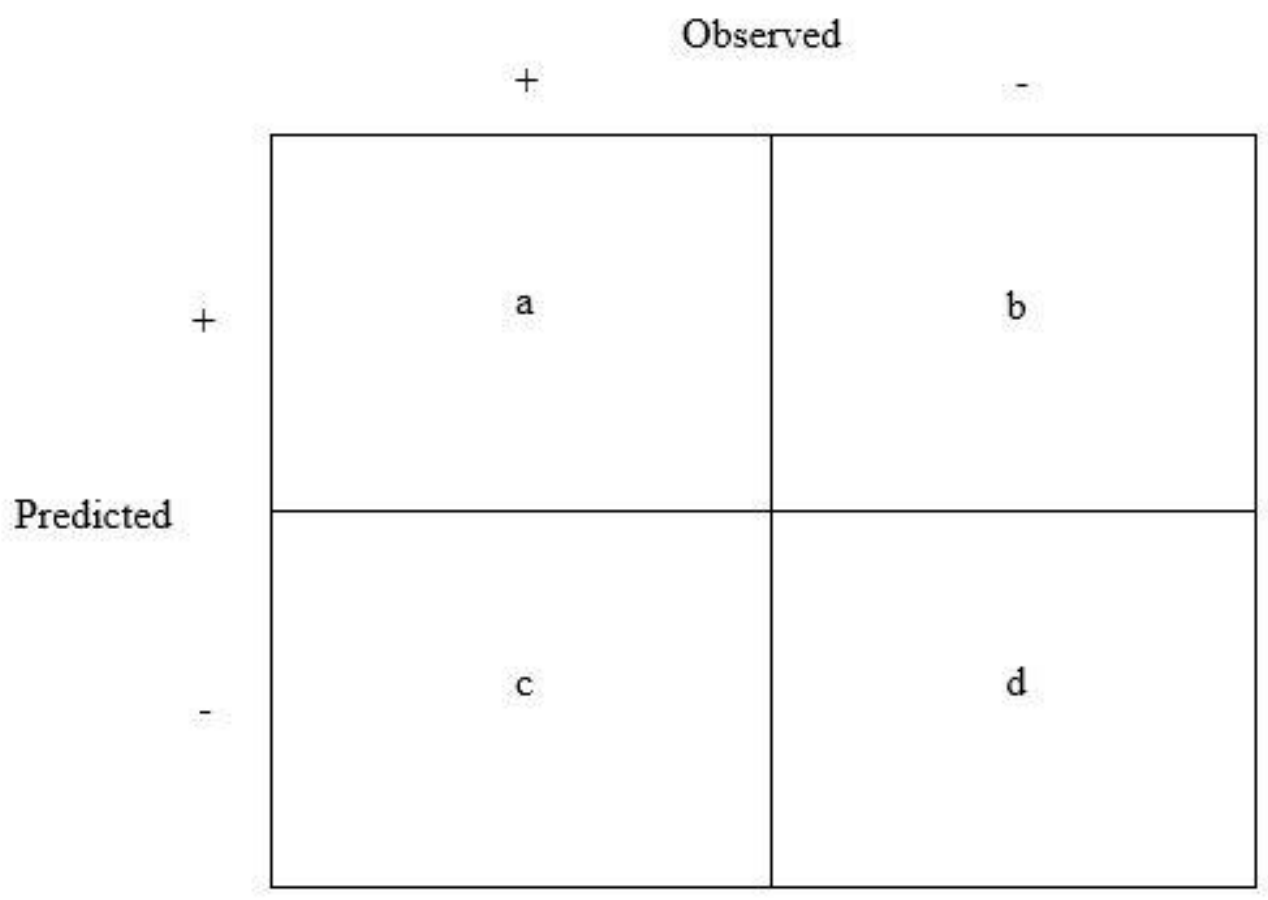

Figure 13. The confusion matrix is often used to test predictions against observations and is comprised of predicted versus observed presences (+) and absences (-) of the four possible occurrence predictions.

$\mathrm{a}=$ true positive $=$ true presence $=$ predicting presence when the species really is present $=$ absence of omission error.

$\mathrm{b}=$ false positive $=$ false presence $=$ predicting presence but the species really cannot grow there

$\mathrm{c}=$ false negative $=$ false absence $=$ predicting absence but the species really can grow there

$\mathrm{d}=$ true negative $=$ true absence $=$ predicting no occurrence when the species really is absent

True positive rate $=$ sensitivity $=\mathrm{a} /(\mathrm{a}+\mathrm{c})$

True negative rate $=$ specificity $=\mathrm{d} /(b+d)$

False negative rate $=$ Error Type $\mathrm{II}=$ omission error $=\mathrm{c} /(\mathrm{a}+\mathrm{c})$

False positive rate $=$ Error Type $I=$ commission error $=b /(b+d)=1$-specificity 
Maxent uses receiver operator characteristic (ROC) analysis to generate an area under the curve (AUC) that plots true positive on the y-axis versus false positive rate (1specificity) on the $\mathrm{x}$-axis for all possible thresholds for inclusion. Therefore, it is considered a threshold independent evaluation of model performance since one number (AUC) is generated for all thresholds. As the false positive rate (x-axis) is allowed to increase to 1.0, we see what happens to the true positive rate (y-axis). A model that is no better than a coin toss (50:50) for predicting inclusion as a presence would have a resultant AUC of 0.5 because the true positive rate would be equal to the false positive rate (a one to one relationship), hence a line on the ROC that has a slope of 1. A perfect predicting model with no misclassification errors would have a resultant AUC of 1.0 because the true positive rate would reach a maximum 1.0 when the false positive rate is at 0.0. In this case, all possible true positives have been predicted accurately by the model with no false positives. It is generally accepted that an AUC between 0.9-1.0 is excellent, $0.8-0.9$ is good, $0.7-0.6$ is fair, $0.6-0.7$ is poor, and $0.5-0.6$ is a failed model because it is no better than the null model.

The bioclimatic variables often used in ecological niche modeling are derived from monthly temperature and rainfall. The variables represent annual trends (Annual Mean Temperature, Annual Precipitation), seasonality (Temperature Annual Range and Annual Precipitation), and severe or limiting factors (Min Temperature of Coldest Month and Max Temperature of Warmest Month, and Precipitation of Wettest Quarter and Precipitation of Driest Quarter). One quarter equals three months (1/4 of one year). The variables are coded:

BIO1 = Annual Mean Temperature $\mathrm{BIO} 2=$ Mean Diurnal Range $($ Mean of monthly $(\max$ temp $-\min$ temp $))$ 
BIO3 = Isothermality $(\mathrm{P} 2 / \mathrm{P} 7)(* 100)$

$\mathrm{BIO} 4=$ Temperature Seasonality (standard deviation *100)

BIO5 = Max Temperature of Warmest Month

BIO6 $=$ Min Temperature of Coldest Month

BIO7 = Temperature Annual Range (P5-P6)

BIO8 $=$ Mean Temperature of Wettest Quarter

BIO9 = Mean Temperature of Driest Quarter

BIO10 = Mean Temperature of Warmest Quarter

BIO11 = Mean Temperature of Coldest Quarter

$\mathrm{BIO} 12=$ Annual Precipitation

BIO13 = Precipitation of Wettest Month

BIO14 $=$ Precipitation of Driest Month

BIO15 = Precipitation Seasonality (Coefficient of Variation)

BIO16 = Precipitation of Wettest Quarter

BIO17 = Precipitation of Driest Quarter

BIO18 = Precipitation of Warmest Quarter

BIO19 = Precipitation of Coldest Quarter

This follows ANUCLIM, except the standard deviation was used for temperature seasonality because a coefficient of variation does not make sense with temperatures between -1 and 1 (WorldClim, 2015). For a complete description, see Hijmans, Cameron, Parra, Jones, \& Jarvis (2005).

Dr. Steinmaus used Manifold Systems software to delineate the worldwide 19 GIS bioclimatic layers available from Bioclim specifically the California borders (Manifold, 2015; WorldClim, 2015). These were utilized as input for the Maxent simulations.

\section{Objective and hypothesis}

Objective: Use the modeling simulations Climex and Maxent to predict Eucalyptus globulus' growth range and invasive potential in California.

Hypothesis: Eucalyptus globulus will continue to escape plantings and invade California coastal regions. 


\section{Assumptions}

- Eucalyptus globulus is capable of escaping plantings and wildland invasion

- Models are good indicators of potential range of Eucalyptus globulus in California

- Climate is the fundamental driver of spread

- Potential invasive species will not succeed if climate is not suitable regardless of other limiting factors

- Additional factors influencing spread are insignificant if climate is not suitable

- Areas susceptible to invasion

- Disturbances facilitating invasion

- Biology (e.g. vegetative reproduction, small seed size, short juvenile period, etc.)

- Model input parameters are suitable

- Models will accurately predict growth range and invasive potential of Eucalyptus globulus

- The 19 bioclimatic variables may not completely describe the fundamental niche that is relevant to the distribution for this modeling task. The fundamental (potential) niche is all the possible locations it could grow. The realized (realistic) niche is where it actually grows. The realized niche is always smaller or equal to than the fundamental niche because of other factors affecting establishment (predation, competition, disease, herbivory, etc.). Climate is the most basal of drivers determining a species fundamental niche. Climate is the main driver describing the fundamental niche of E. globulus. 


\section{Chapter 4}

\section{Results}

\section{Anticipated results}

Eucalpytus globulus populations will likely increase and invade coastal and neighboring inland valleys in California. Eucalpytus globulus' preference for riparian habitat and moisture will control distribution and invasive range. Climate will be the fundamental factor influencing its invasive range in California.

\section{Model results}

Both the Climex and Maxent models show E. globulus having invasive potential along coastal California. However, the Maxent California model shows minimal central valley growth while the Climex model shows no growth in California central valleys. Any E. globulus populations growing in California central valleys were planted by humans. Central valley populations, e.g. windbreaks, were also nurtured during early growth stages when water is crucial for E. globulus saplings. Established saplings have root systems large enough to reach water underground. Eucalyptus globulus should not require any human intervention for invasive consideration. Without help, E. globulus

probably cannot naturally grow in central valley areas locations; therefore, it should not be growing in those locations invasively. Additionally, the Climex data does not specifically focus on the riparian habitat E. globulus prefers. The Ecoclimatic Index is the default setting in Climex. Selecting other map options allows the map to display stresses. Figure 25 shows cold stress preventing E. globulus from growing in northern California and dry stress preventing it in southern California. Maxent uses actual tree 
location presence data while Climex is a climatic matching simulation. Maxent used tree locations for populations that may have been cultivated, especially during establishment, so caution must be exercised when predicting success. If E. globulus can be facilitated through establishment, then the Maxent predictions are accurate (S. Steinmaus, personal communication, March 08, 2015). 


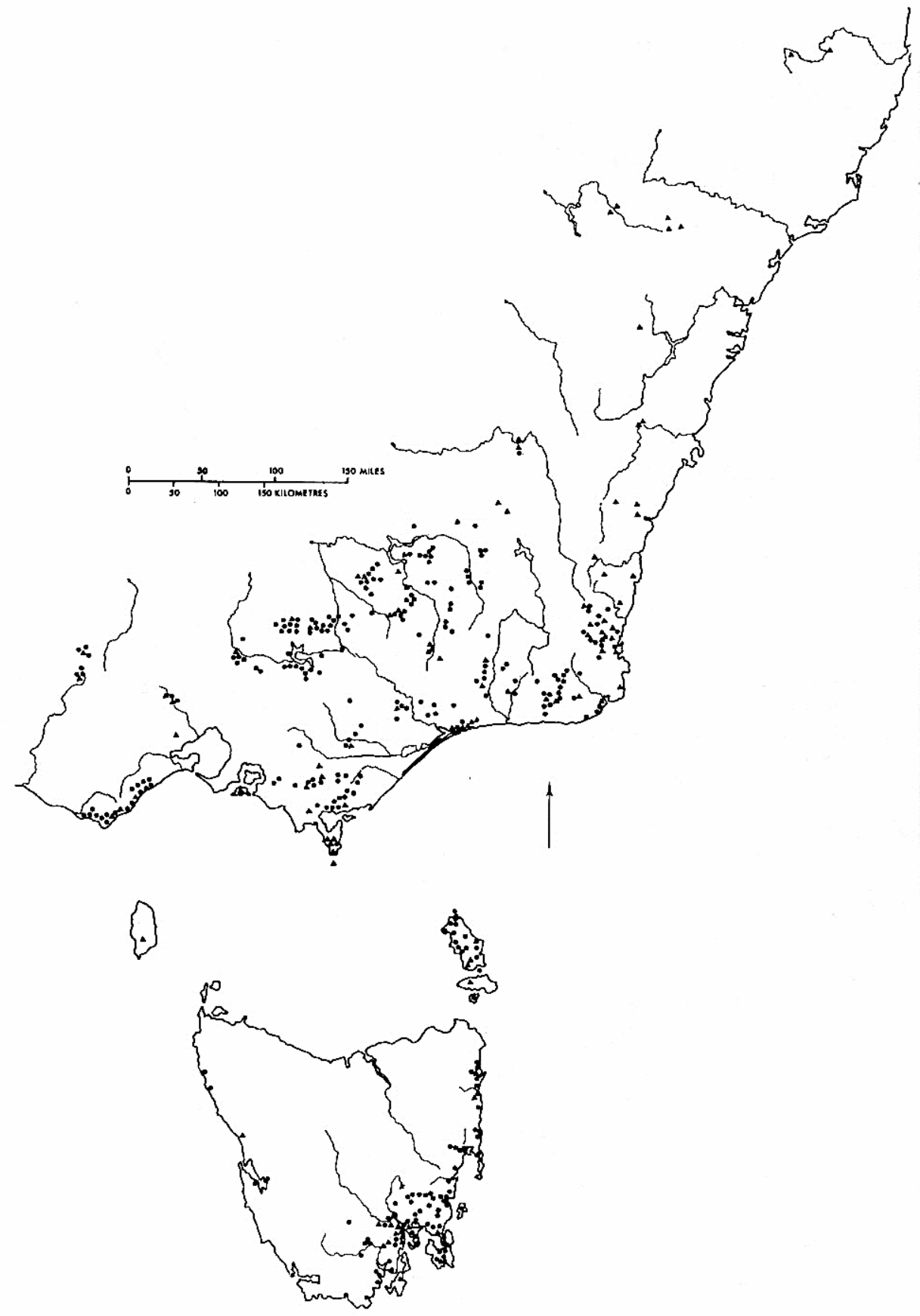

Figure 14. Native distribution of Eucalyptus globulus in southeastern Australia and Tasmania (Kirkpatrick, 1975). 


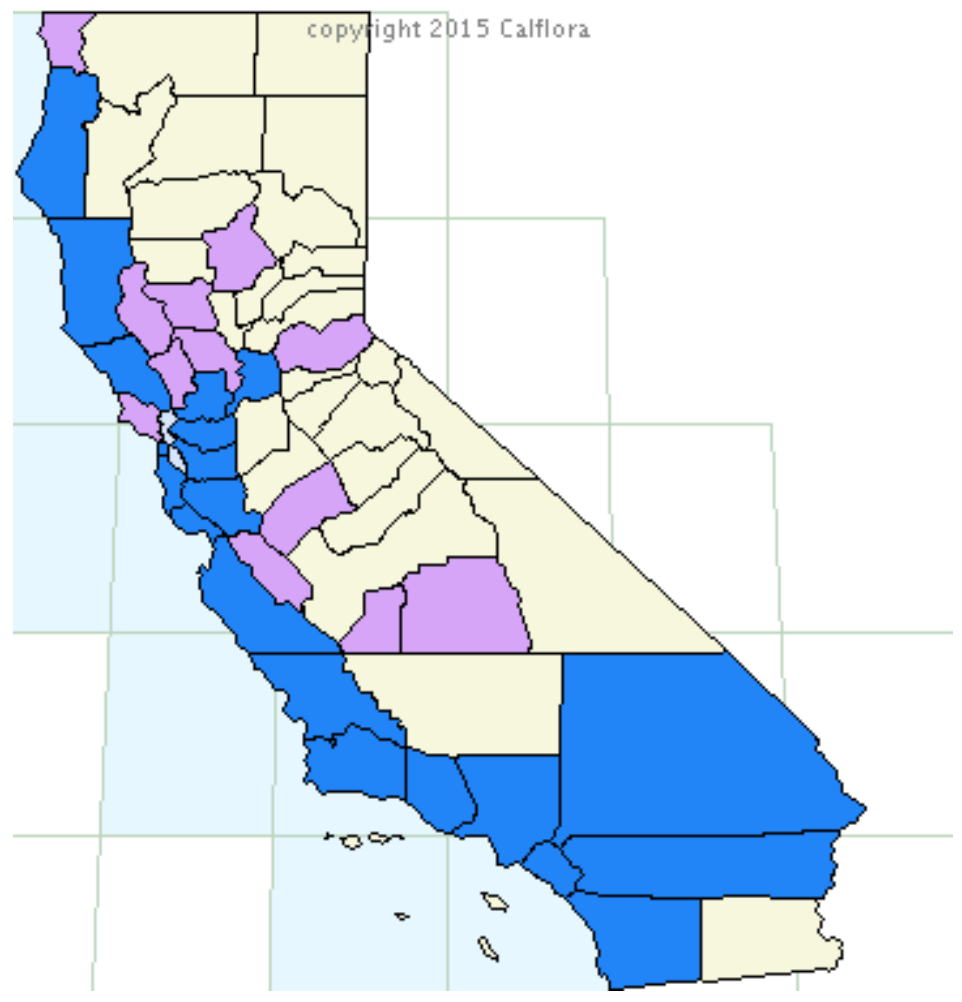

Figure 15. Eucalyptus globulus distribution range by county in California. Blue indicates counties with herbarium specimen records. Purple indicates counties with reported records (Calflora, 2015). 


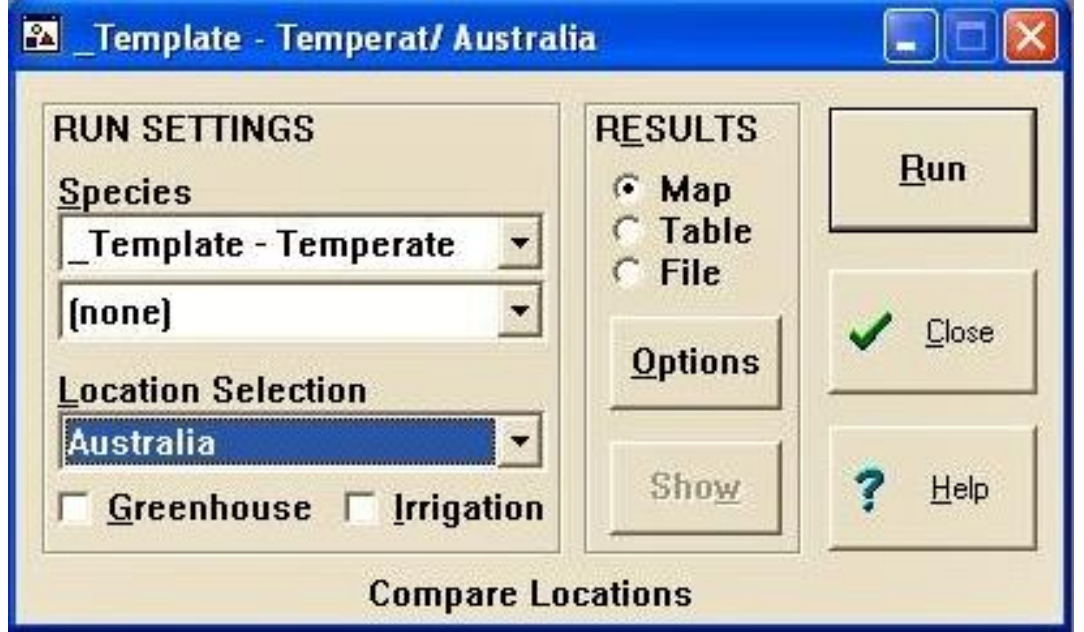

Figure 16. Comparing locations in Climex (temperate template and Australia). 


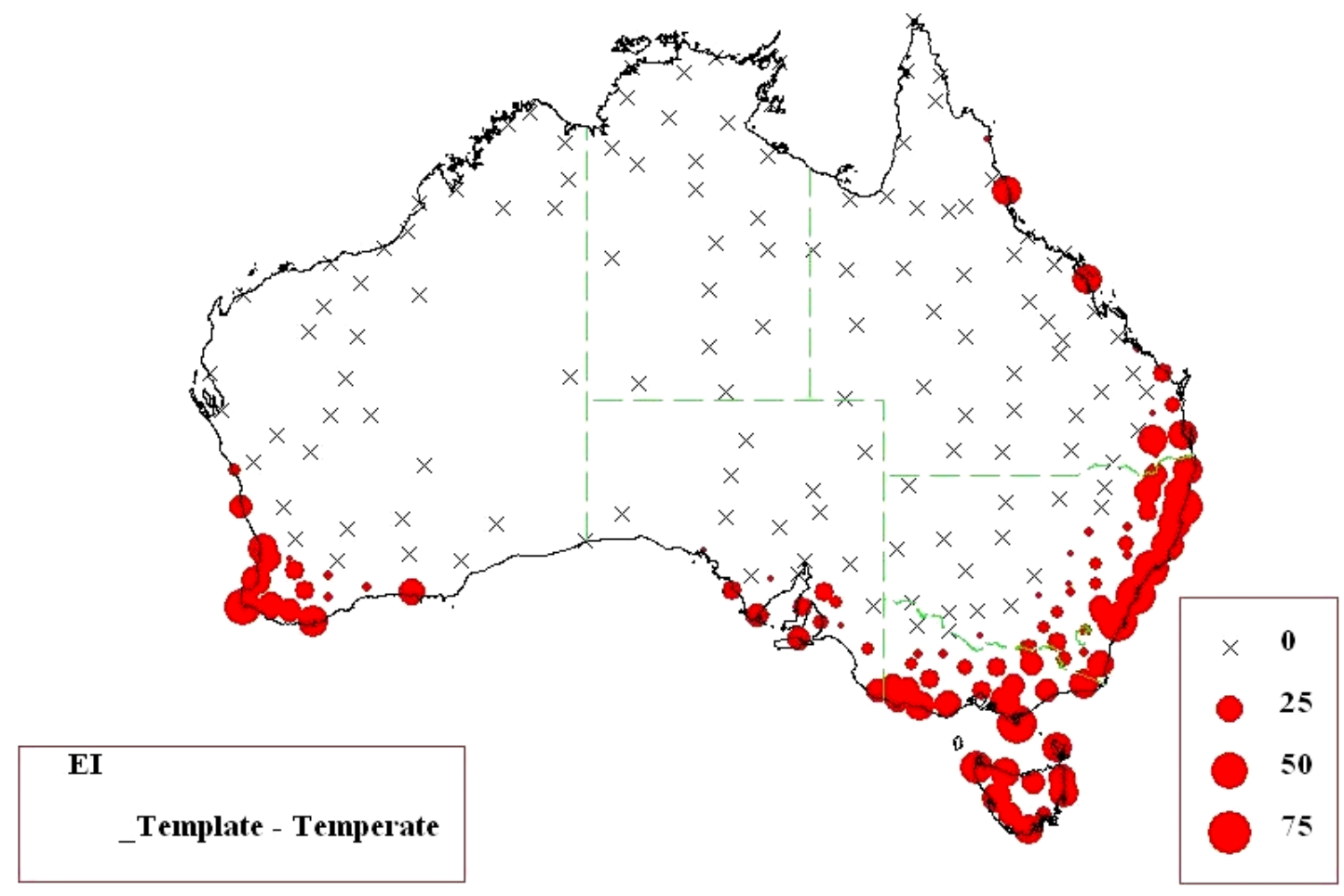

Figure 17. Climex temperate template model of Australia. 


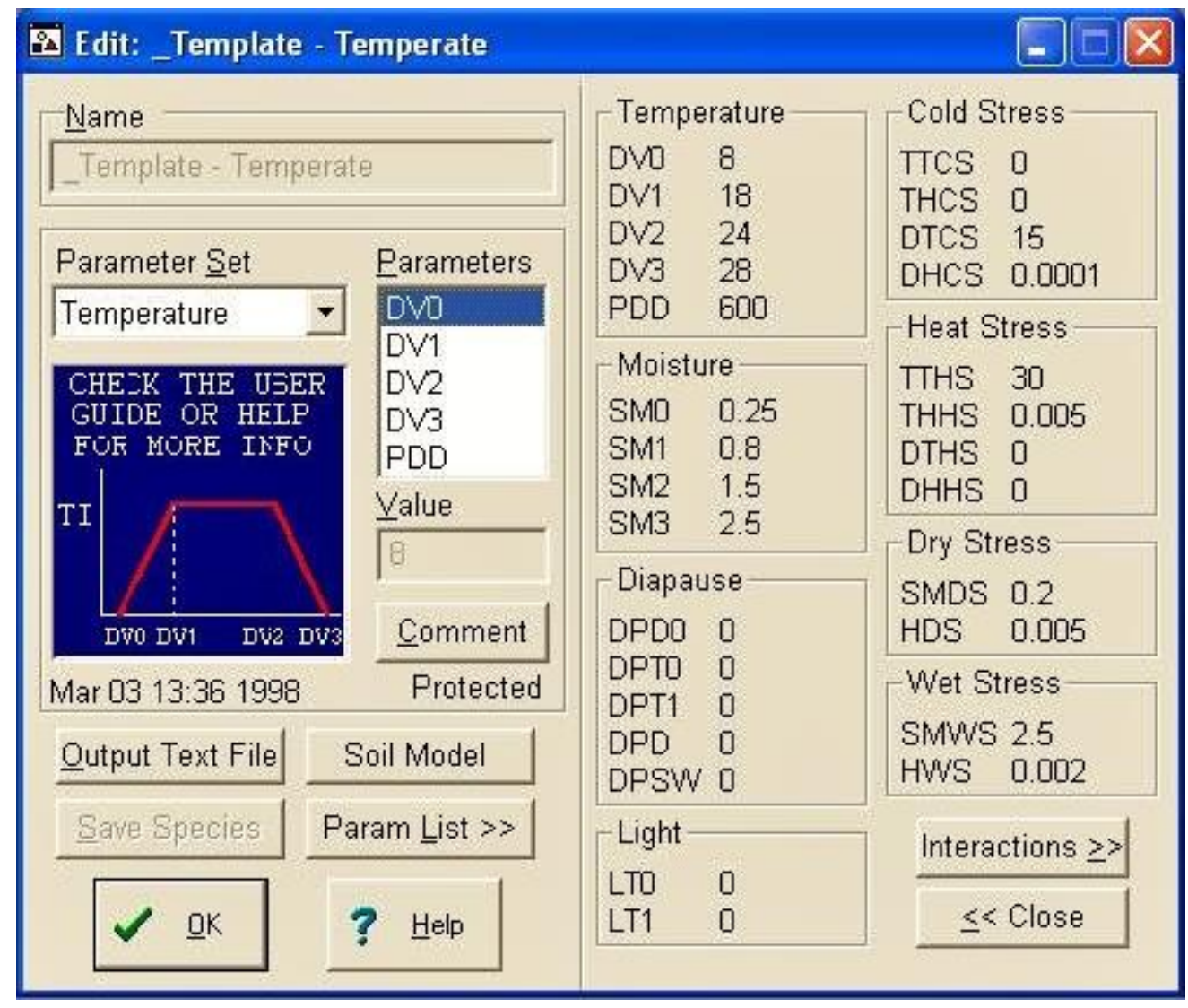

Figure 18. Climex temperate template climate parameters. 


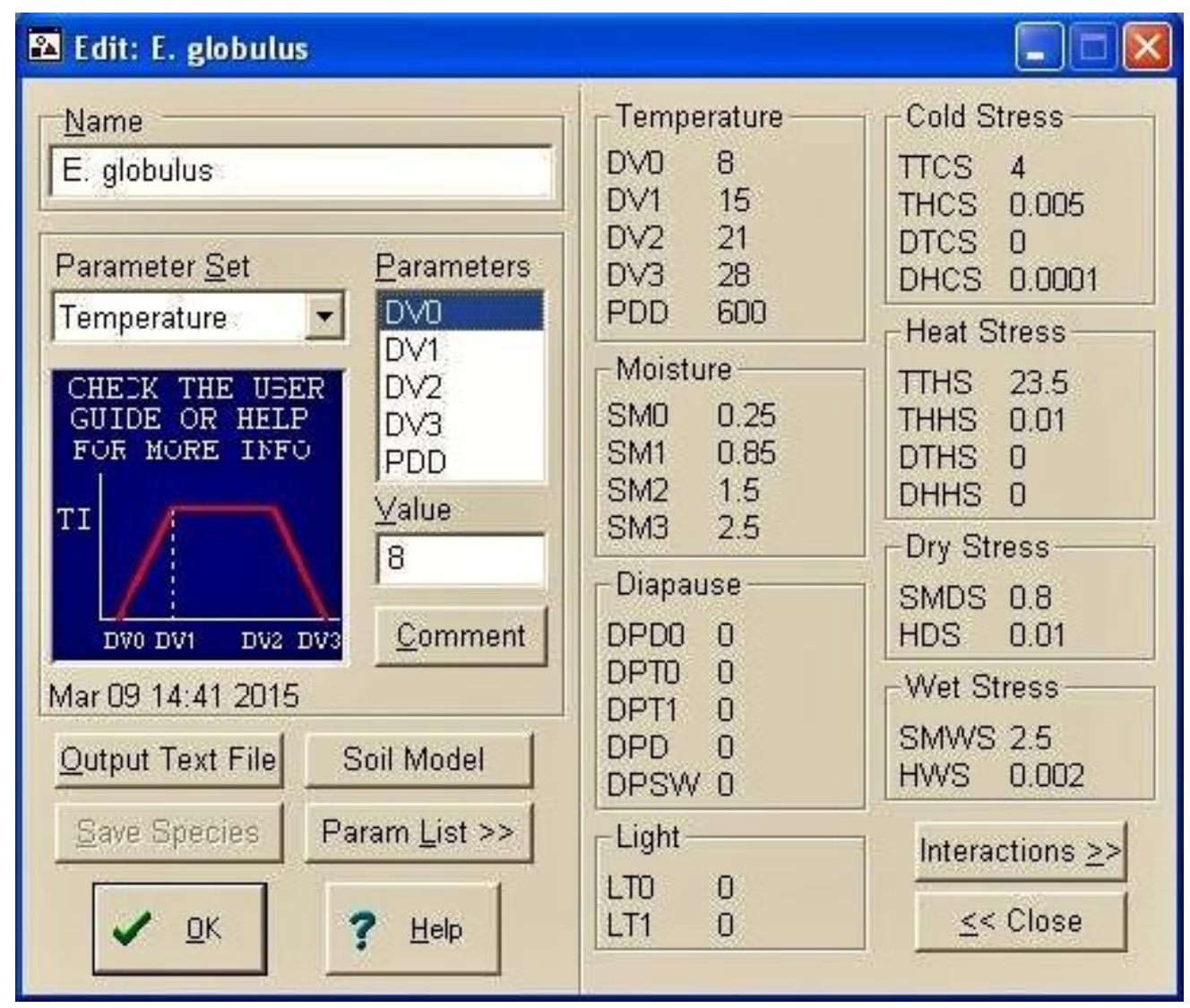

Figure 19. Parameter fitting. 


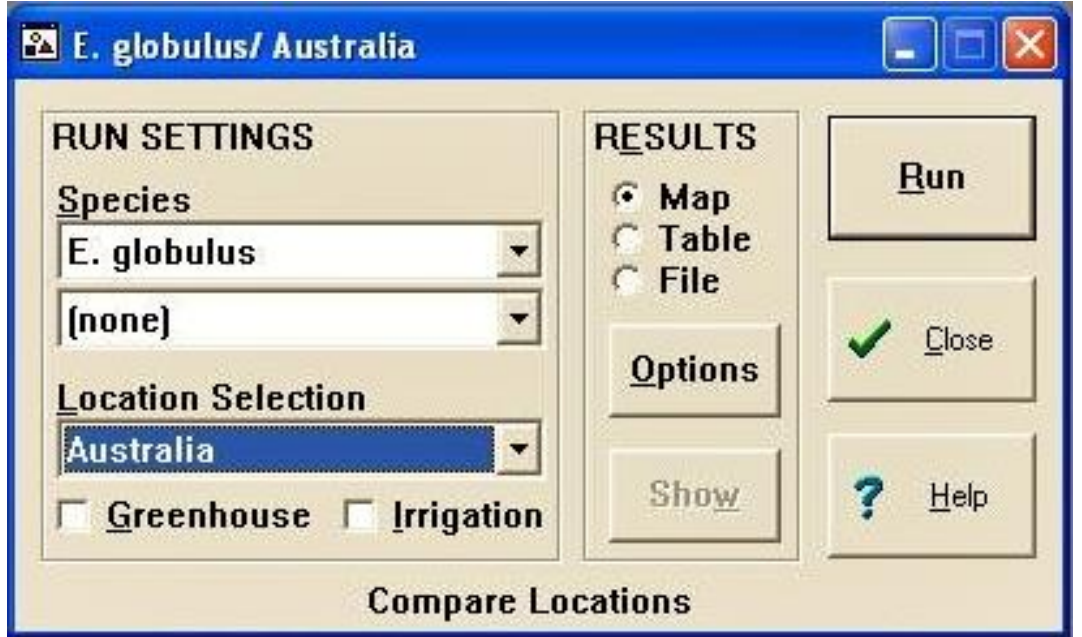

Figure 20. Comparing locations (E. globulus and Australia). 


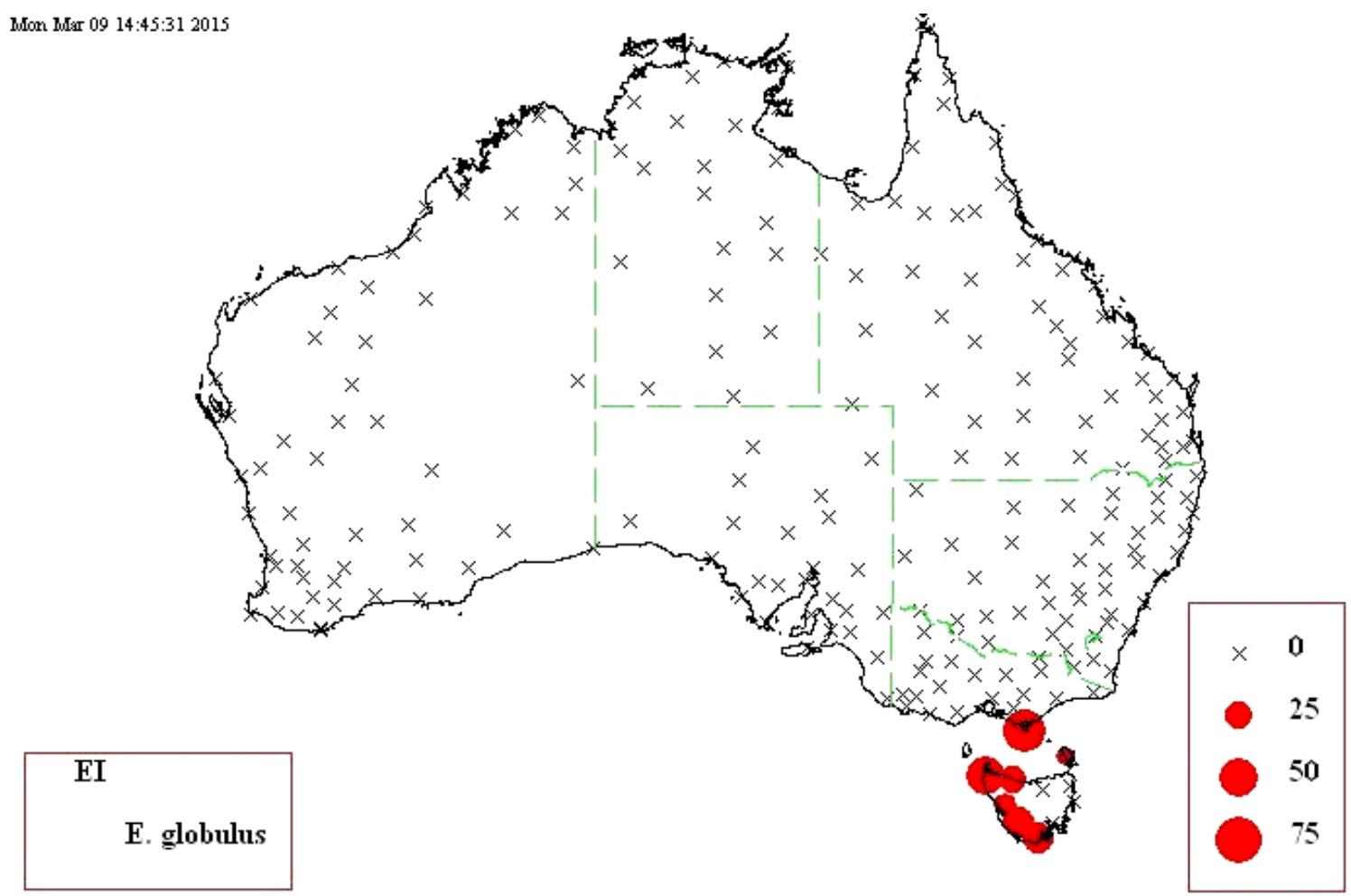

Figure 21. The Climex model for the native distribution of E. globulus using the manipulated parameters. 


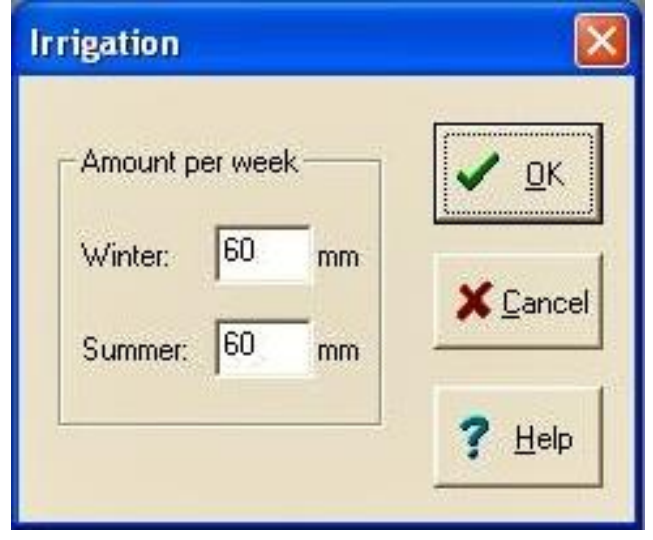

Figure 22. Fog drip data modeled using the irrigation scenario. 


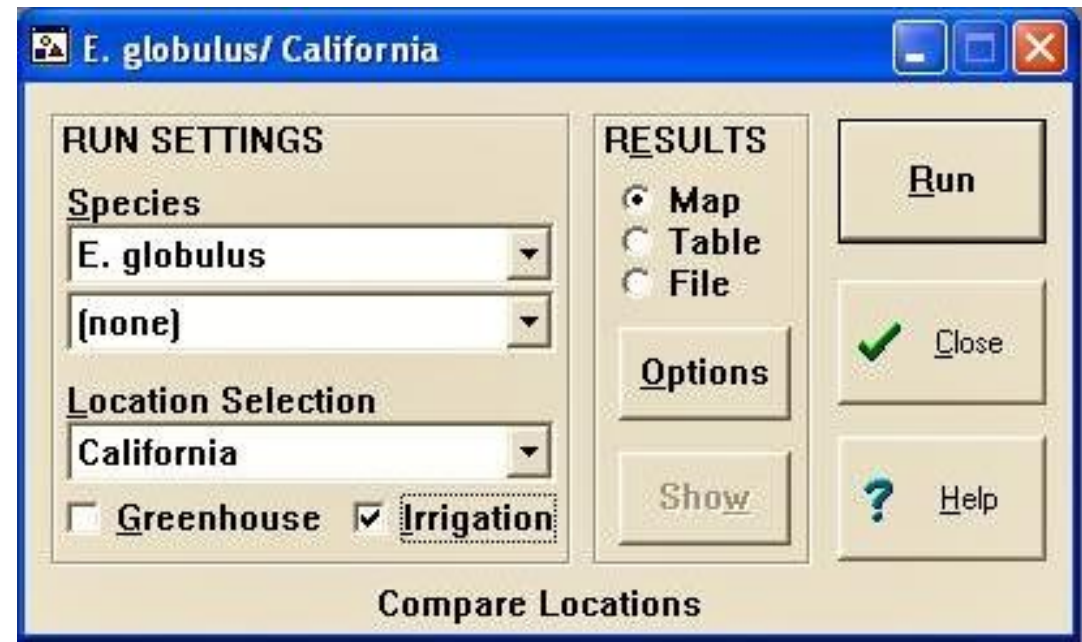

Figure 23. Comparing E. globulus and California using the irrigation scenario. 


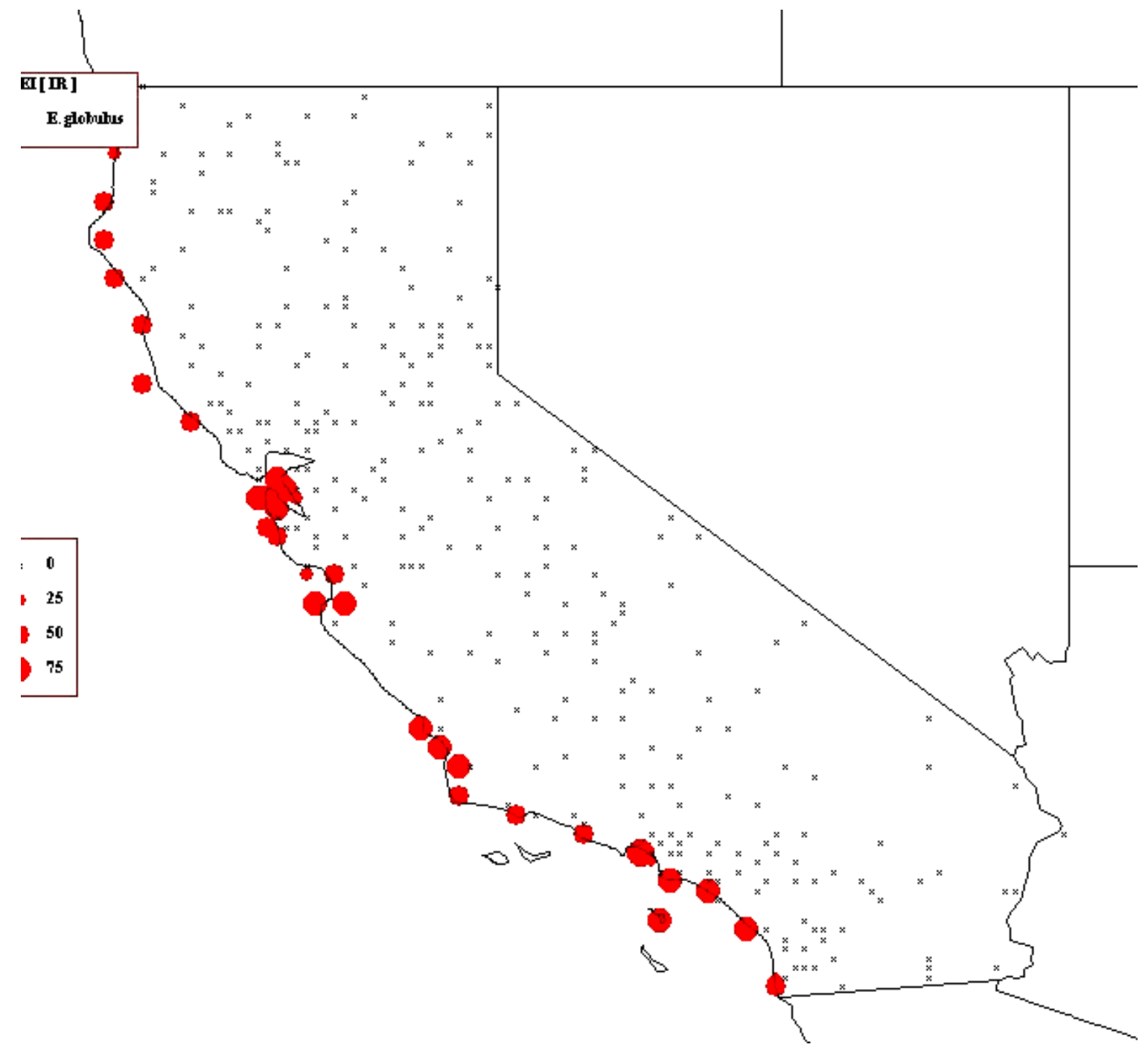

Figure 24. Predicted invasive potential of E. globulus in California, modeled by Climex. 


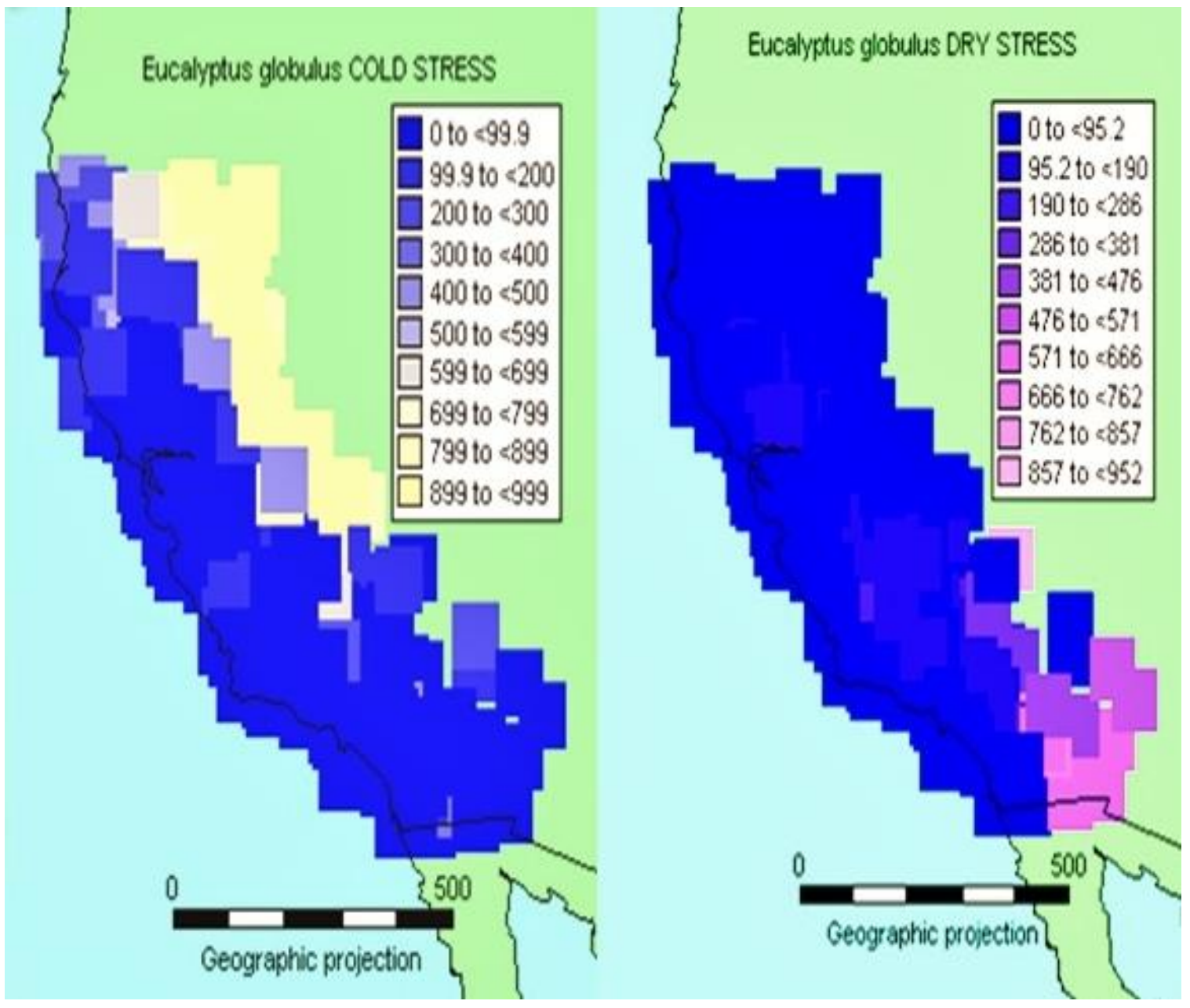

Figure 25. Climex predicts cold stress prevents E. globulus growth in northern California, and dry stress prevents growth in southern California. 
Maximum Entropy Species Distribution Modeling, Version 3.2.19
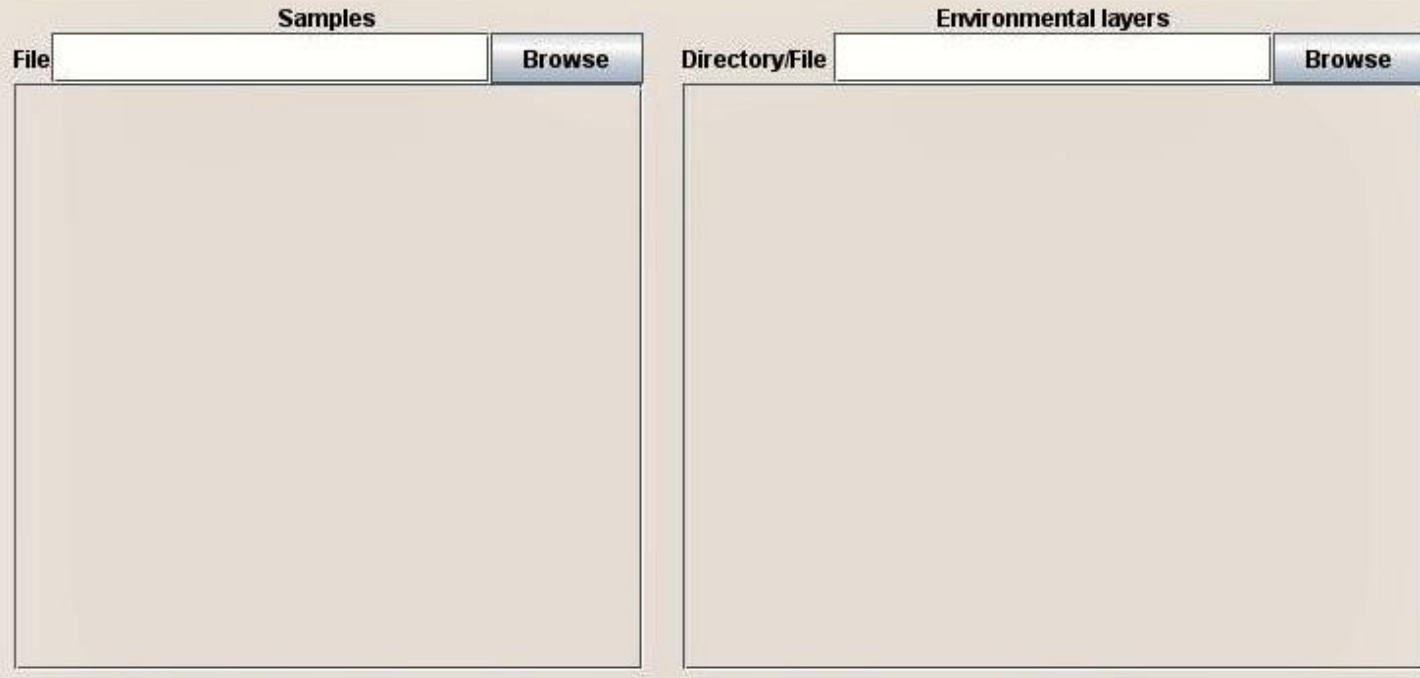

$\square$ Linear features Create response curves

$\square$ Quadratic features Make pictures of predictions

$\square$ Product features

\begin{tabular}{|c|c|c|c|}
\hline & \multicolumn{3}{|c|}{ Do jackknife to measure variable importance $\square$} \\
\hline & Output format & Logistic & $\nabla$ \\
\hline & Output file type & asc & $\nabla$ \\
\hline Output directory & & \multicolumn{2}{|c|}{ Browse } \\
\hline Projection layers directoryifile & & \multicolumn{2}{|c|}{ Browse } \\
\hline \multicolumn{2}{|l|}{ Settinas } & & \\
\hline
\end{tabular}

Figure 26. Maxent requires presence data ("Samples" i.e. GPS coordinates), a directory containing environmental data ("layers" i.e. variables), and an output locale ("directory" i.e. results location) (Phillips, 2005). 
Samples

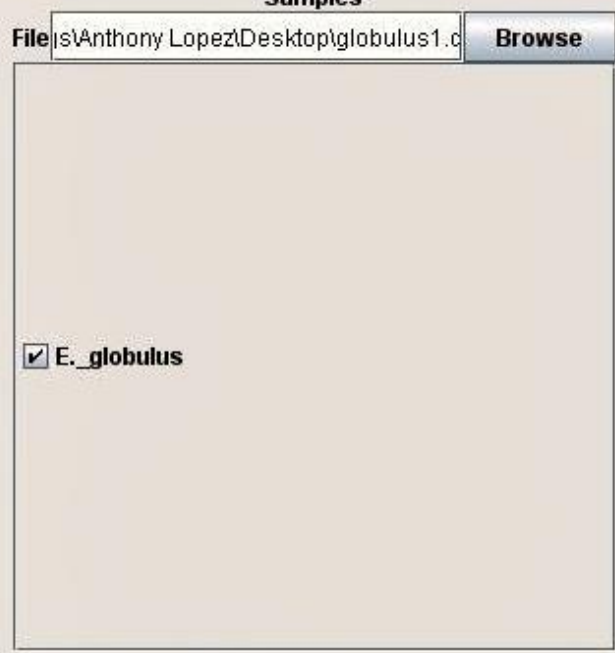

Linear features

Quadratic features

$\square$ Product features

$\square$ Threshold features

$\square$ Hinge features

Auto features
Ervironmental layers

\begin{tabular}{|c|c|c|c|}
\hline \\
\hline Directory/File Desktopimaxentic & ifmaxentimaxent.cache & Browse & \\
\hline \multirow{2}{*}{$\begin{array}{l}\text { 10MeanTempWarmMonCA } \\
V \text { 11MeanTempColdMonCA }\end{array}$} & Continuous & $\nabla$ & 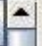 \\
\hline & Continuous & $\nabla$ & \\
\hline V 12AnnPrecipCA & Continuous & $\nabla$ & \\
\hline V 13PrecipWetMonCA & Continuous & $\nabla$ & \\
\hline V 14PrecipDryMonthCA & Continuous & $\nabla$ & \\
\hline V 15PrecipSeasonalityCVCA & Continuous & $\nabla$ & \\
\hline V 16PrecipWetQuartCA & Continuous & $\nabla$ & \\
\hline$\checkmark$ 17PrecipDryQuartcA & Continuous & $\nabla$ & \\
\hline V 18PrecipWarmQuartcA & Continuous & $\nabla$ & \\
\hline$\checkmark$ 19PrecipColdQuartCA & Continuous & $\nabla$ & \\
\hline V 1AnnMeanTemp CA & Continuous & $\nabla$ & $=$ \\
\hline Select all & Deselect a & & \\
\hline
\end{tabular}

Create response curves $v$

Make pictures of predictions $v$

Do jackknife to measure variable importance $v$

Output format Logistic

Output file type .asc

Output directory sianthony LopeziDesktopimaxentitutorial-data2loutputs Browse Projection layers directoryfile

Browse

Help

Figure 27. The Maxent program screen after browsing and selecting the appropriate files for E. globulus localities (Samples), California environmental variables (layers), and output destination (directory). 
Samples

File IsiAnthony LopeziDesktopiglobulus1.0 Browse

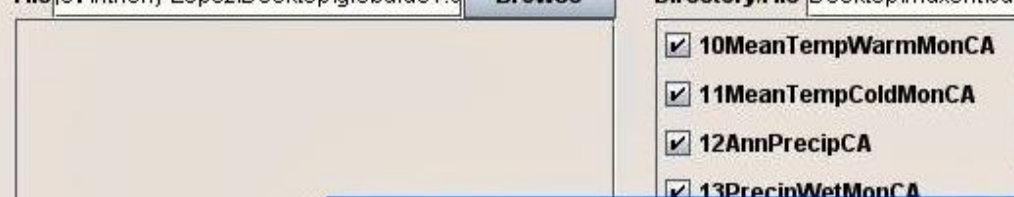

Ermir onmental layers

Directory/File Desktopimaxenticalifmaxentimaxent.cache Browse

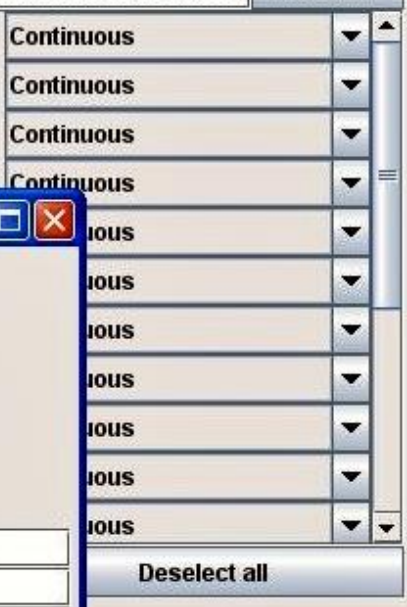

Create response curves $v$ 0.00001 Maximum iterations Corvergence threshold

Quadratic features

Product features Max number of background points 10000 \begin{tabular}{|l||l|}
\hline Bias file & Browse \\
\hline
\end{tabular} pictures of predictions $v$ Test sample file Browse sure variable importance $v$

Threshold features

$\square$ Hinge features 술 Maximum Entropy Parameters 10 $\square$ Remove duplicate pre
Random test percentage Regularization multiplie

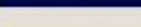

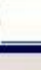

\begin{tabular}{|c|c|c|c|}
\hline Output format 1 & $\log$ & istic & $\nabla$ \\
\hline Output file type. & .asc & & \\
\hline orial-data2toutput & & Bre & \\
\hline & & & \\
\hline
\end{tabular}

Figure 28. Options are selected to create response curves, make pictures of predictions, and perform jackknife testing to measure variable importance. Clicking "Settings" allows "Random test percentage" parameter entry to designate (the amount of) data set aside for model validation. 


\section{Samples}

File|siAnthony LopeziDesktopiglobulus1.0 Browse

V. E. globulus
Ervironmental layers

Directoryifile Desktopimaxenticalifmaxentimaxent.cache Browse v. 10MeanTempWarmMonCA

V 11MeanTempColdMonCA

V 12AnnPrecipCA

V 13PrecipWetMonCA

V 14PrecipDryMonthCA

v 15PrecipSeasonalityCVCA Continuous

\section{Maximum Entropy Species Distribution Modeling}

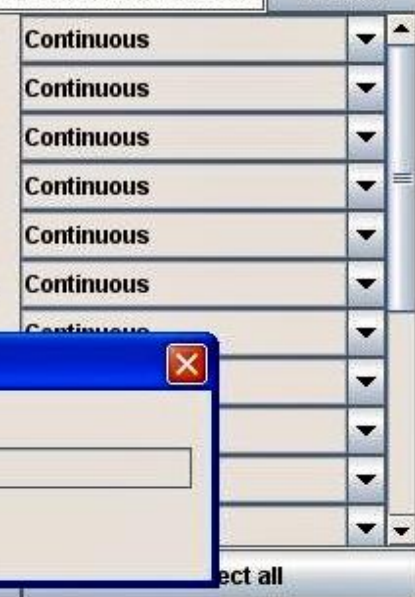

Linear features

Quadratic features

Make pictures of predictions $\sqrt{v}$

Product features

Do jackknife to measure variable importance $v$

Threshold features

Hinge features

E. globulus 3Isothermality CA: Gain is $\mathbf{2 . 5 4 5 3 2 2}$

Auto features

Output directory इiAnthony LopeziDesktopimaxentitutorial-data2loutputs

Output format Logistic

Output file type .asc Projection layers directoryifile

Settings

Brows

Run

Help

Figure 29. Pressing the "Run" button initiates distribution modeling. A progress bar monitors and illustrates progression and describes the steps taken during the process. 


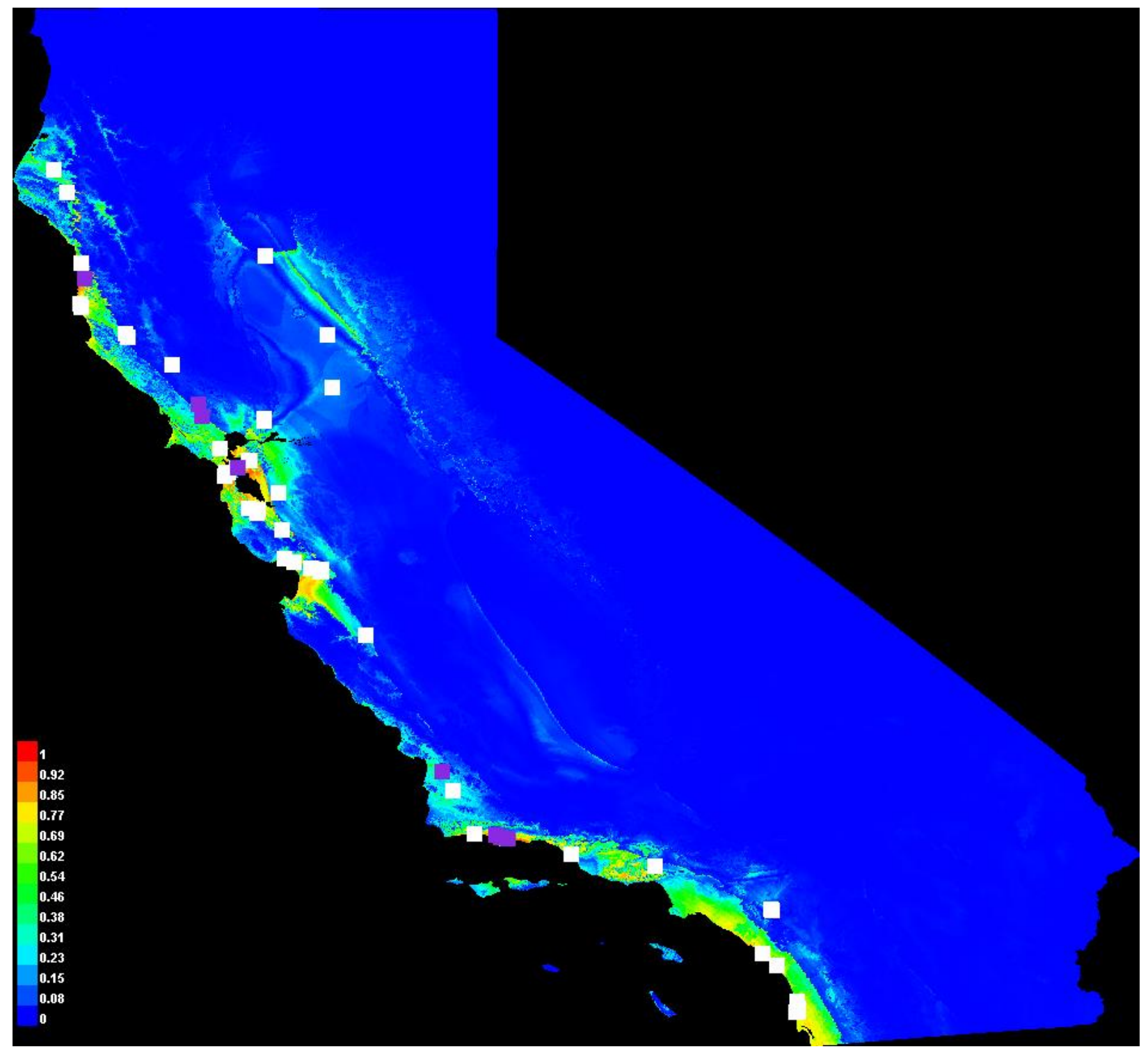

Figure 30. Maxent model picture representation for Eucalyptus globulus in California.

Suitable condition probability is predicted using colors in the model picture representation. Areas with better suitable condition predictions are indicated in warmer colors. Red indicates high suitability probability, green indicates typical location conditions, and lighter blue shades indicate low suitable condition probability. White 
dots show training presence locations, and violet dots show test locations. Test points are random samples from the presence locations (Phillips, 2005). Figure 30 shows suitability probability for E. globulus is typical along coastal California and highly probable in coastal Humboldt County, Mendocino County, the San Francisco Bay Area, Santa Cruz and the Monterey Peninsula, and from coastal Santa Barbara County south to the Mexican border. A northern land strip, from the Redding area down through Roseville, also shows suitable location conditions. Most of the Channel Islands show suitable conditions, and Santa Cruz Island, in particular, shows a small area with highly probable predicted conditions.

The first step in evaluating the Maxent model is to verify that it is significantly better than random. Verification is first accomplished using a threshold-dependent binomial test of omission and predicted area. The binomial test requires thresholds to convert Maxent predictions into binary predictions defining suitable and unsuitable areas (Phillips et al., 2006).

Model performance is first observed using the omission rate and predicted area. Omission rate is the fraction of test data not predicted as suitable. The predicted area is the fraction predicted as suitable. The null hypothesis states that the model is no better than random (Phillips et al., 2006).

Second, performance is evaluated using threshold-independent receiver operating characteristic (ROC) curve analysis. ROC analysis characterizes model performance (at all thresholds) by calculating the area under the curve (AUC). The AUC provides a single measure of performance independent of thresholds (Phillips et al., 2006). The two errors that lead to poor predictions are ommission error and commission error. 
Ommission error is the model predicting E. globulus should not grow in a location (probablity of occurrence in Maxent is zero or EI = zero in Climex) but it actually can. Commission error is the opposite: the model indicates E. globulus should grow in a location (probablity of occurrence in Maxent is positive or EI > 0 in Climex) but it actually cannot. Reducing ommission error (only) to zero results in high commission error. Commission error of zero results in high ommission error, so Maxent strives to find the best balance where error is (most) minimal (S. Steinmaus, personal communication, October 08, 2015).

Figure 31 shows testing and training omission and predicted area variance with a cumulative threshold (Phillips, 2005). Ten percent of sample data was randomly set aside ("Random test percentage") for statistical analysis/model validation, and the model is built on the other 90\% (Phillips, 2005; S. Steinmaus, personal communication, September 20,2014). Statistical analysis uses a binary prediction threshold to predict suitable conditions above and unsuitable below the threshold.

Figure 31 illustrates what happens to the model predictions when the threshold is raised, tightening the threshold for occurrence (i.e. the standards for the map to glow are tightened). The cumulative threshold ranges from easy standards of suitability for occurrence at zero to more stringent (difficult), and conditions must be optimal for the model to predict suitability at one hundred. So, glowing predicted locations where $E$. globulus can grow are exact matches in terms of the bioclimatic variables (high temperature, rainfall, hottest month of the year, etc.) with the extremely stringent threshold. A cumulative threshold of zero would result in the entire map being one solid color equal to a probability/color of 1 because suitability conditions are so loose. The 


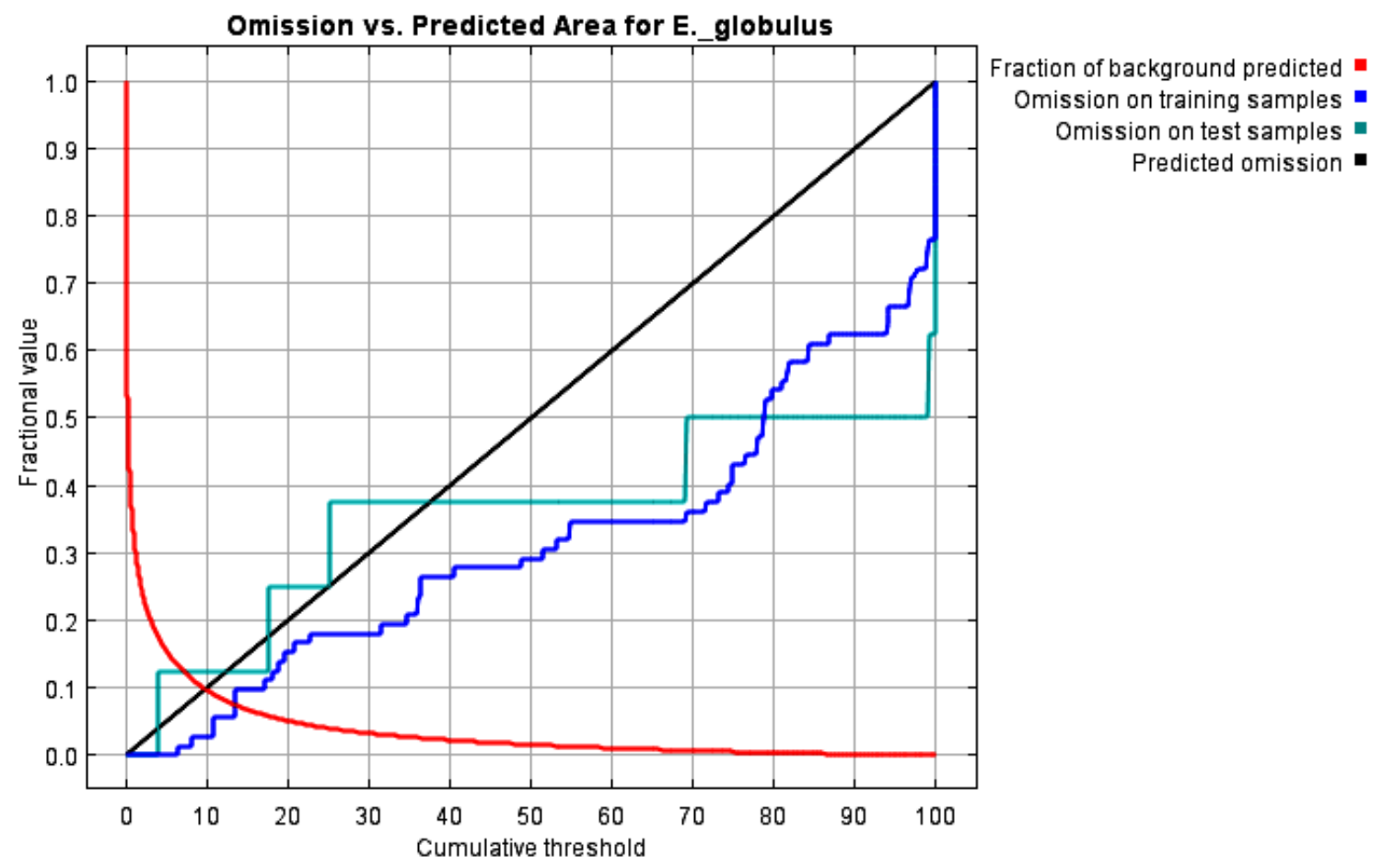

Figure 31. Omission vs. predicted area for Eucalyptus globulus.

ommission on training samples curve predicts that a location is not suitable for $E$. globulus. The omission on test samples curve uses the actual samples. Omission matches the predicted Maxent distribution omission rate well, so the model is validated (S. Steinmaus, personal communication, October 08, 2015). Figure 31 also shows the omission test line dropping below the predicted line. This is because test and training data are not independent, having come from the same presence data (Phillips, 2005). Future research can include larger, purely random, independent test data sets for additional validation.

Cumulative output is defined by the Maxent distribution's predicted omission rates (Phillips \& Dudík, 2008). Omission rate and predicted area are shown as cumulative threshold functions. The straight line is the predicted omission rate by the cumulative 


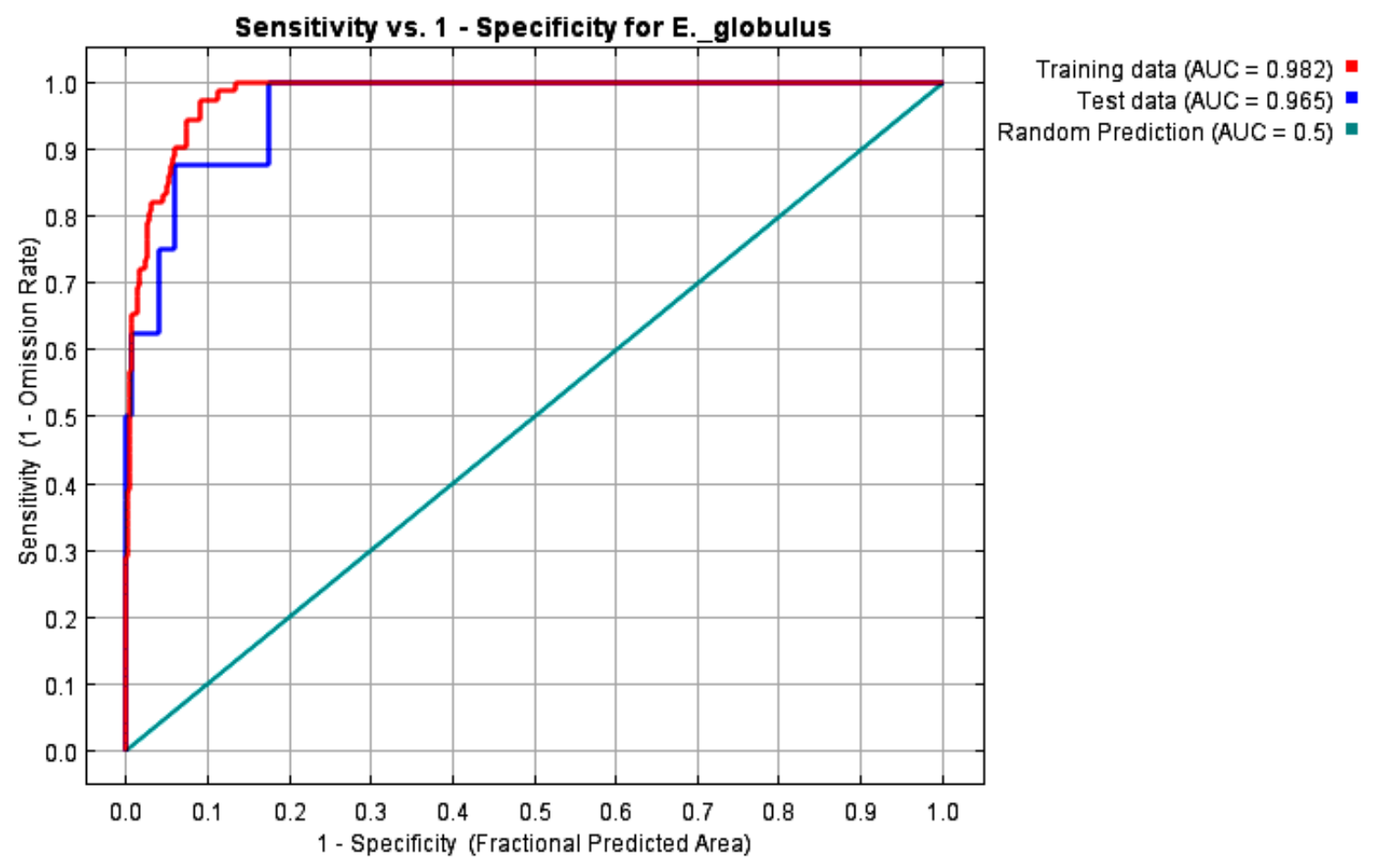

Figure 32. ROC (receiver operating curve) for training and test data.

output definition (Phillips, 2005). The omission rate is calculated using training presence records (and test records if test data is used). It should be close to the predicted omission because of the cumulative threshold definition (Maxent analysis of omission/comm). For specific thresholds and omission rates with P-values, see Appendix A.

Figure 32 is the ROC (receiver operating curve) for training and test data. The standards for inclusion in the predicted area are loosened. Suitability is easily predicted at one and difficult to predict at zero. A perfect predicting model (AUC $=1)$ would indicate all the exact climatic variables that absolutely determine E. globulus success and death and that climate is the only factor determining success. The random prediction line is purely random prediction (e.g. coin toss) for each location and displays an ROC curve for pure random prediction. The training model is the data set of randomly selected sites 
used to build the model. The test model used the data set aside for validation (jagged because of few sites) and roughly follows the training set, thereby relatively validating the model. The AUC values ( 0.982 for the training set and 0.965 for test/validation) indicate the model's accuracy (S. Steinmaus, personal communication, October 08, 2015). These very high values (near 1.0) indicate high accuracy based on the AUC values in the literature of Phillips, Anderson, \& Schapire (2006).

Note predicted area defines specificity, not true commission (Maxent analysis of omission/commission). Fractional predicted study area is used instead of commission rate because the data is presence data with no absence data (Phillips, 2005). Specificity (fractional predicted area) is the fraction of negative instances, and there are no negative instances (absences) to measure specificity when only presence data is available (Phillips et al., 2006). The maximum value of the area under the curve (AUC) is less than 1 for presence data (Wiley, McNyset, Peterson, Robins, \& Stewart, 2003). One minus specificity (A) equals commission error (Phillips, 2005).

The red (training) line shows the model fit to training data. The blue (testing) line indicates the model fit to test data and really tests the model prediction. The turquoise line represents the expected line if the model is no better than random. A blue (test) line falling below the turquoise line indicates the model performs worse than a random model. The further the blue line is toward the graph's top left, the better the model's data test sample presence predictions. Species with narrow ranges tend to have higher AUC values relative to the environmental data describing the study area (Phillips, 2005).

Table 1 estimates the contributions of environmental variables to predicting probability of suitability. Temperature range is the most important indicator/predicting 
variable overall (high probability) for most locations (i.e. E. globulus is highly sensitive to temperature range). The mean temperature of the wettest quarter and the mean temperature of the driest month are not informative, low probability indicators. Optimal locations (curve peaks) are likely coastal California locations (with corresponding mean variable values) where E. globulus thrives. Most contribution between temperature range and the variables that are not informative is minimal but still correlative (S. Steinmaus, personal communication, October 08, 2015). Estimates are determined by adding the increase in gain to the corresponding variable's contribution (or subtracting it if the change to the absolute value is negative) (Phillips, 2005).

Maxent answers what variables matter most for the species distribution model. Environmental variables making the greatest model contribution are tracked while the Maxent model is trained. Each algorithm step increases the model's gain by modifying the single feature coefficient. Maxent assigns the gain increase to the variable(s) the feature depends on. Table 1 gives converted percentages estimating the relative contributions of the environmental variables. The contributions are estimates, so they depend on the path the Maxent code uses for the optimal solution. Additionally, percentages should be interpreted cautiously with highly correlated environmental variables because correlation may hide interpretation ability (i.e. the model uses sets of variables changing together) (Phillips, 2005).

Response curves indicate how individual environmental variables influence the Maxent prediction (Figure 33). They show the difference between different feature types. The curves show the logistic prediction change for each environmental variable. The values on the y-axes are suitability probability predictions from the logistic output. 


\begin{tabular}{|r|r|}
\hline \multicolumn{1}{|c|}{ Variable } & Percent contribution \\
\hline 7TempRangeCA & 66.9 \\
\hline 14PrecipDryMonthCA & 12.5 \\
\hline 15PrecipSeasonalityCVCA & 5.6 \\
\hline 13PrecipWetMonCA & 3.3 \\
\hline 4TempSeasonalityCA & 3.1 \\
\hline 10MeanTempWarmMonCA & 2.4 \\
\hline \hline 12AnnPrecipCA & 1.2 \\
\hline \hline 19PrecipColdQuartCA & 1 \\
\hline \hline 2DiurnalTempRange CA & 0.7 \\
\hline \hline 17PrecipDryQuartCA & 0.7 \\
\hline \hline 16PrecipWetQuartCA & 0.6 \\
\hline \hline 18PrecipWarmQuartCA & 0.5 \\
\hline \hline 6MinTempCA & 0.4 \\
\hline \hline 1AnnMeanTemp CA & 0.4 \\
\hline \hline 3Isothermality CA & 0.3 \\
\hline \hline 5MaxTempCA & 0.3 \\
\hline \hline 11MeanTempColdMonCA & 0.2 \\
\hline \hline 8TempWetQuartCA & 0 \\
\hline \hline 9MeanTempDryMonCA & 0 \\
\hline \hline
\end{tabular}

Table 1. Variable contribution analysis.

Strongly correlated variables can be difficult to interpret because the model may be determined by correlations not evident in the response curves (i.e. the Maxent model may use sets of changing variables). Response curves using only the corresponding variable illustrate the dependence of prediction suitability on both the variable and correlations between the variable and other variables (Phillips, 2005).

The response curves are probabilities for the corresponding variable on the Maxent 
map. Each response curve represents a Maxent model created using only the selected variable to predict success probability. Each curve illustrates how E. globulus responds to the variable labeled in terms of probability of occurrence. The curves reveal the predicted suitability dependence on both the selected variable and on correlations between selected variables and other variables. Different climatic variables are predicting the probability of success for different locations based on slope of the response curve. Strong correlations between variables may be easier to interpret. For example, the precipitation variables are all highly correlated (e.g. high annual precipitation areas have high precipitation during the wettest month), and isothermality (temperature evenness) is highly correlated with temperature range. Flat lines are not informative and do not predict success or death, because there is no fluctuation across the range of variable values. Other variables are informing the model and doing the predicting when the curve does not fluctuate, but those other variables were not informative when the curve does fluctuate (i.e. for specific locations, the fluctuating selected variable was a great and perhaps the only suitability predictor). Decreasing curves with greater daily fluctuations indicate stress, and the probability of success for E. globulus decreases (S. Steinmaus, personal communication, October 08, 2015). For contrasting marginal response curves, see Appendix B.

A jackknife test provides alternate variable importance estimates. Jackknife testing excludes each individual variable and creates a model with the remaining variables, models each variable in isolation, and a model including all variables. The jackknife results appear in three bar charts (Phillips, 2005). Jackknife testing is a resampling method that repeatedly (maximum iteration is 500) builds a model using a subset of 
1AnnMeanTemp CA

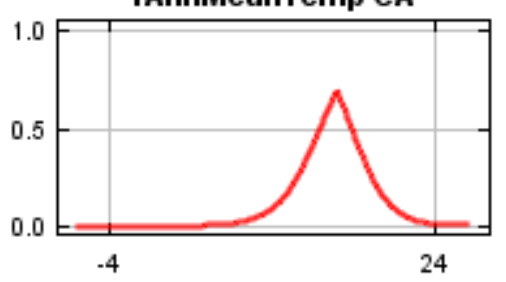

3Isothermality CA

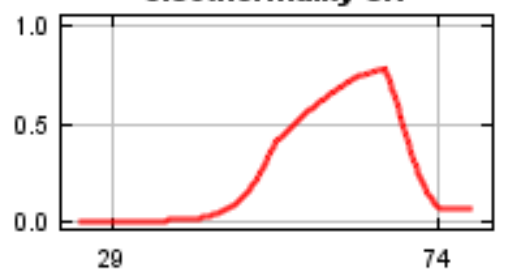

5MaxTempCA

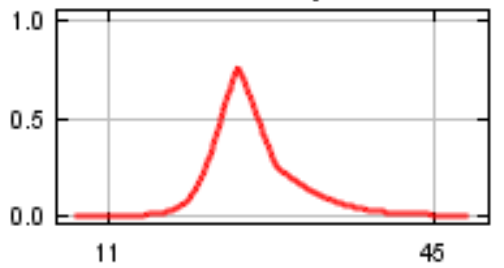

7TempRangeCA

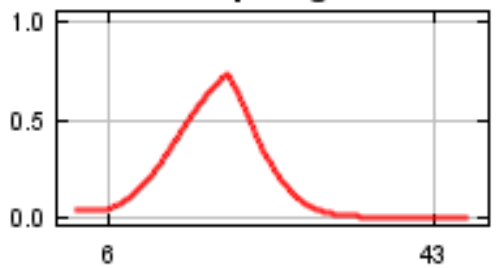

9MeanTempDryMonCA

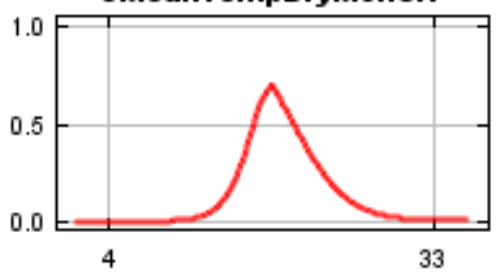

2DiurnalTempRange CA

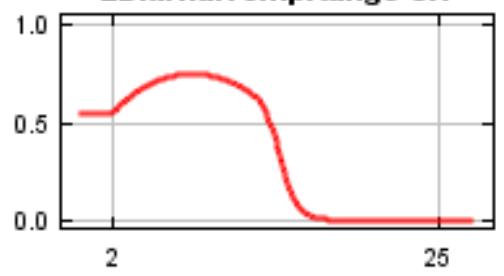

4TempSeasonalityCA

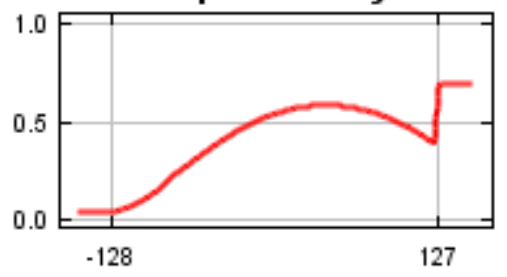

6MinTempCA

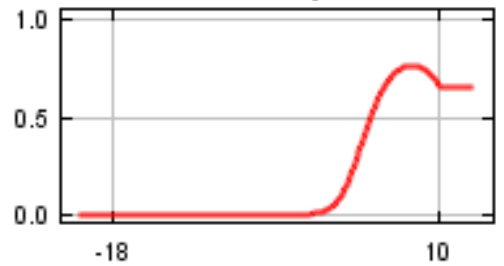

8TempWetQuartcA

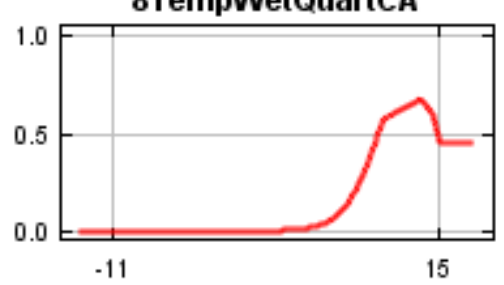

10MeanTempWarmMonCA

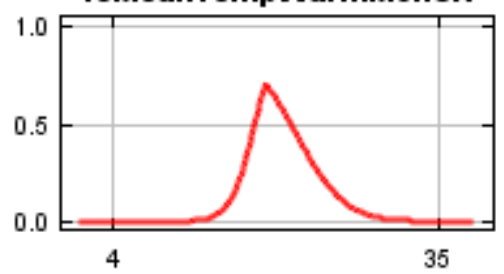



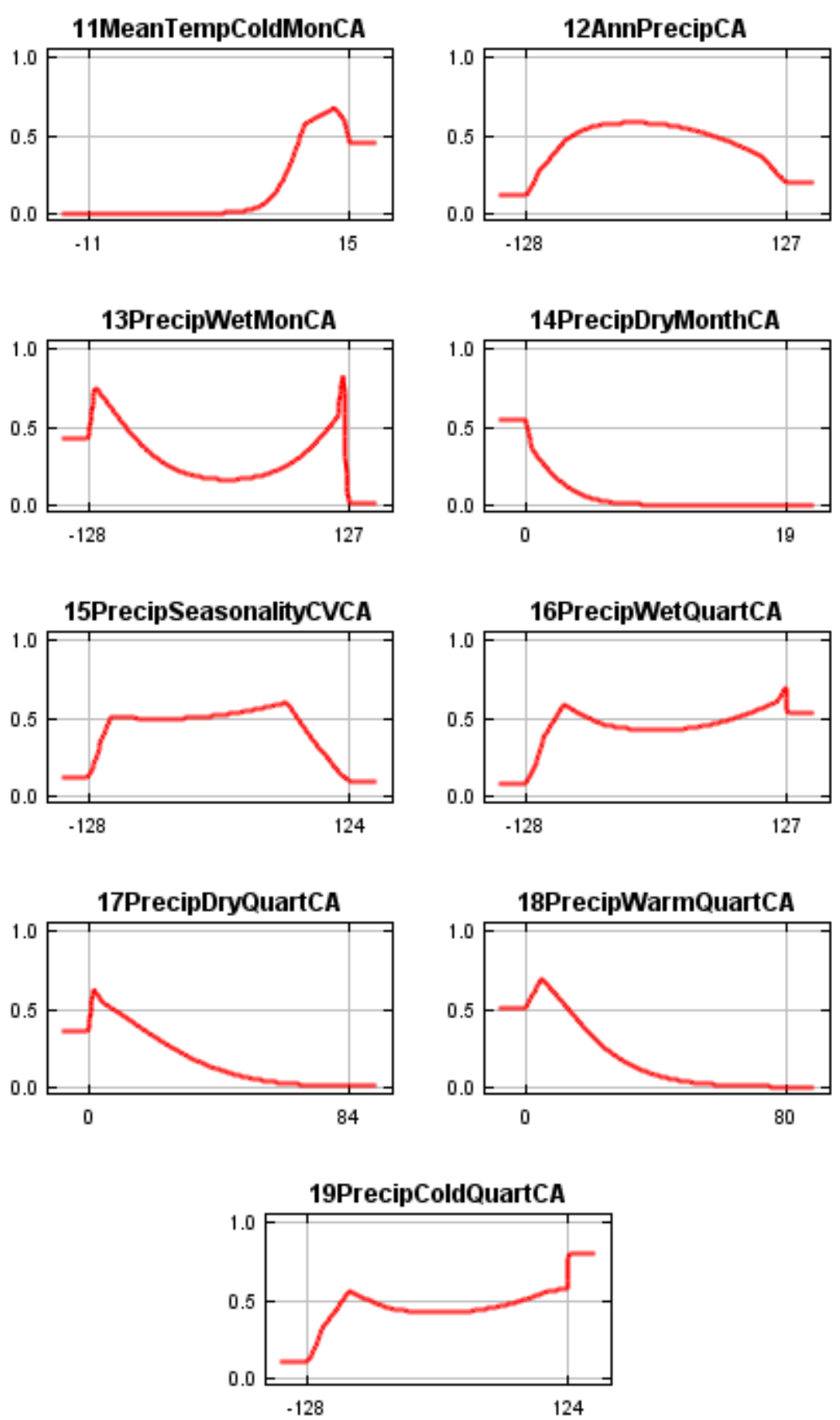

Figure 33. Response curves using only the corresponding variable.

randomly selected locations. Then, an average AUC is computed and presented here.

Figure 34 is the jackknife test for variable importance which shows the environmental 
variable with the highest gain, and therefore the most useful information in isolation, is annual temperature range (7TempRangeCA). The variable decreasing the gain the most when omitted and which therefore contains the most information not present in other variables is precipitation seasonality (15PrecipSeasonalityCVCA). The graph shows almost no gain if Maxent uses precipitation of coldest quarter (19PrecipColdQuartCA), so that variable is not individually useful for E. globulus distribution estimation. Annual temperature range (7TempRangeCA) displays a reasonably solid fit to the training data. No environmental variables contain substantial useful information not already contained in other variables because omitting each did not cause a substantial decrease in training gain (Phillips, 2005).

It is important to compare all three jackknife graphs. The AUC graph (Figure 36) has the highest gain and is the best model using all the variables. The graph predicts performance using the AUC and shows annual temperature range (7tempRangeCA) is the most effective single variable predicting the testing occurrence data distribution. The relative importance of temperature range also increases in the test gain graph compared to the training gain graph. Light blue bars longer than the red bar in the test gain and AUC graphs indicate improvement in performance when corresponding variables are not used. This indicates which variables are helping Maxent fit the training data and that prediction improves when corresponding variables are not used (i.e. temperature range better generalizes and gives comparatively better test data results). Models constructed with variables longer than the red bar are less transferable when applying the model to future climate variables and estimating future distribution after climate changes. It makes sense these variables are less transferable: likely suitable conditions for E. globulus will depend 
on the aggregate. The test gain graph also shows models made only with precipitation seasonality (15PrecipSeasonalityCVCA) and temperature seasonality (4TempSeasonalityCA) result in a negative test gain indicating the model is worse than a null model (uniform distribution) for predicting the testing occurrences distribution (Figure 35) (Phillips, 2005). 


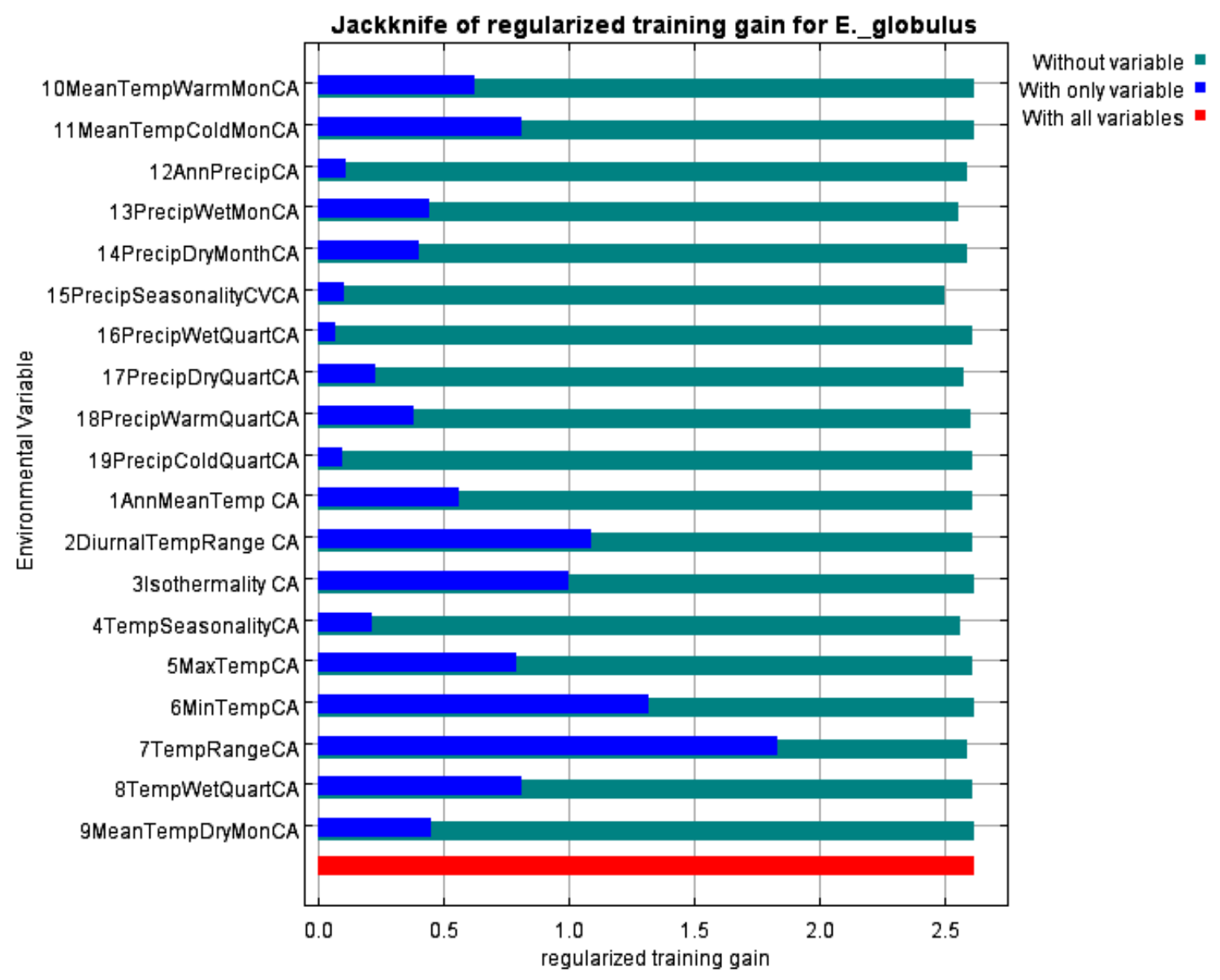

Figure 34. Jackknife test for variable importance. 


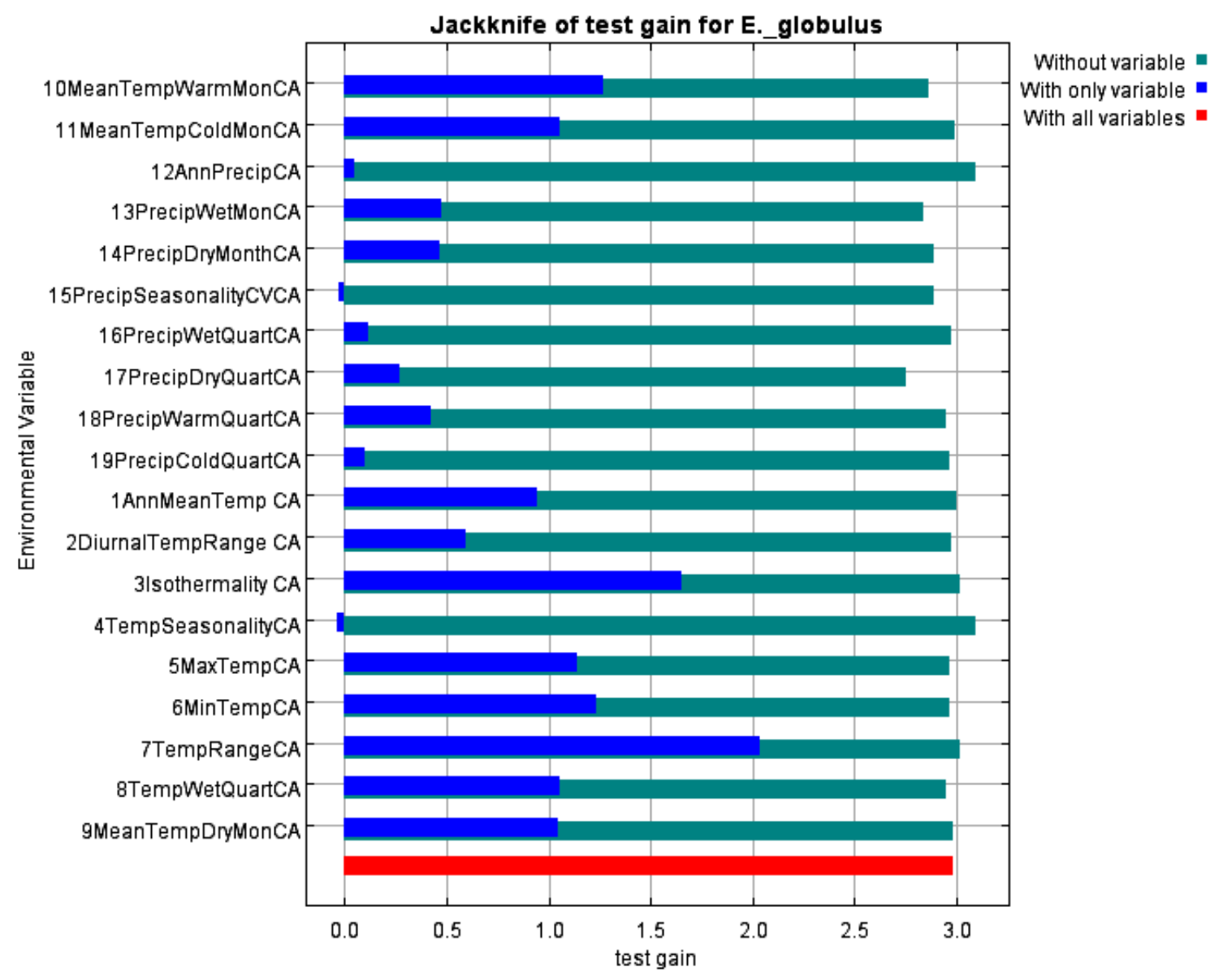

Figure 35. Jackknife test using test gain. Conclusions about the most important variables can change with test data. 


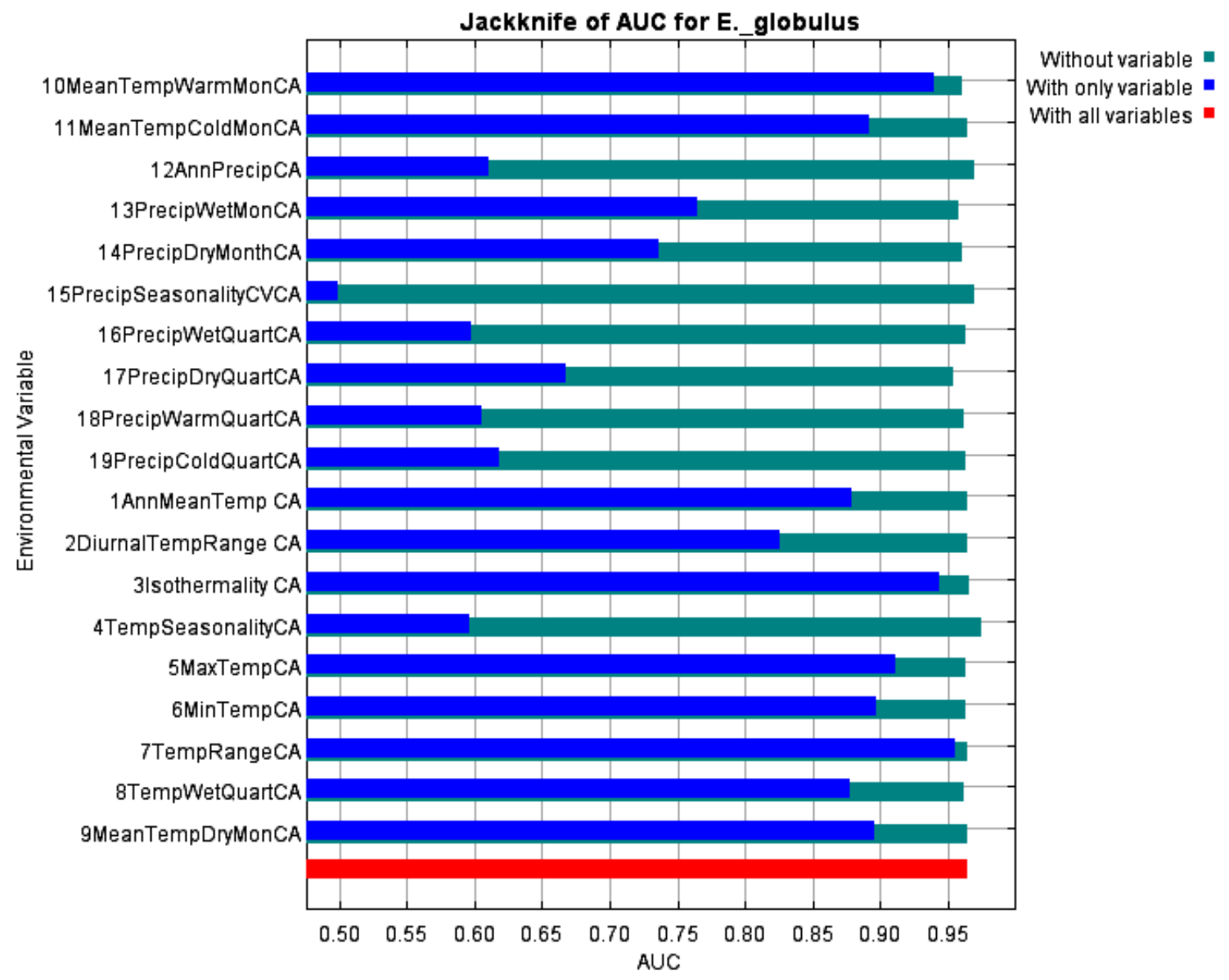

Figure 36. Jackknife test using AUC on test data. 


\section{REFERENCES}

Abrams, M. (1990). Adaptations and responses to drought in Quercus species of North America. Tree Physiology, 7, 227-238.

Alden, J., \& Hermann, R. K. (1971). Aspects of the cold-hardiness mechanism in plants. The Botanical Review, 37(1), 37-142.

Allelochemical. (2015). In Oxford Dictionaries online. Retrieved from http://www.oxforddictionaries.com/us/definition/american_english/allelochemical

Almeida, M. H., Pereira, H., Miranda, I., \& Tomé, M. (1995, February). Provenance trials of Eucalyptus globulus Labill. in Portugal. In B. M. Potts, N. M. G. Borralho, J. B. Reid, R. N. Cromer, W. N. Tibbits, \& C. A. Raymond (Eds.), Eucalypt plantations: improving fibre yield and quality (pp. 195-198). Proceedings of the CRC-IUFRO Conference, Hobart, Tasmania. Sandy Bay, Tasmania: Cooperative Research Centre for Temperate Hardwood Forestry.

Anderson, R. P., \& Martinez-Meyer, E. (2004). Modeling species' geographic distributions for preliminary conservation assessments: an implementation with the spiny pocket mice (Heteromys) of Ecuador. Biological Conservation, 116(2), 167179.

Ashton, D. H. (1981). Fire in tall open-forests (wet sclerophyll forests). In A. M. Gill, R. H. Groves, \& I. R. Noble (Eds.), Fire and the Australian biota (pp. 339-366). Canberra, Australian Capital Territory, Australia: The Australian Academy of Science.

Awe, J. O., Shepherd, K. R., \& Florence, R. G. (1976). Root development in provenances of Eucalyptus camaldulensis Dehn. Australian Forestry, 39(3), 201-209.

Bachmann, K., Chambers, K. L., \& Price, H. J. (1985). Genome size and natural selection: observations and experiments in plants. In T. Cavalier-Smith (Ed.), The evolution of genome size (pp. 267-276). Chichester, United Kingdom: John Wiley \& Sons.

Bais, H. P., Vepachedu, R., Gilroy, S., Callaway, R. M., \& Vivanco, J. M. (2003). Allelopathy and exotic plant invasion: from molecules and genes to species interactions. Science, 301(5638), 1377-1380.

Bean, C., \& Russo, M. J. (1986). Element Stewardship Abstract for Eucalyptus globulus (Tasmanian blue gum). Arlington, VA: The Nature Conservancy.

Bell, C. E., DiTomaso, J. M., \& Wilen, C. A. (2007). Pest notes: invasive plants. University of California Agriculture \& Natural Resources Publication 74139. Davis:University of California Statewide Integrated Pest Management Program 
(UCIPM). Retrieved from

http://www.ipm.ucdavis.edu/PMG/PESTNOTES/pn74139.html

Bell, D. T., \& Williams, J. E. (1997). Eucalyptus ecophysiology. In J. E. Williams \& J. Woinarski (Eds.), Eucalypt ecology. Individuals to ecosystems (pp. 168-196). New York, NY: Cambridge University Press.

Bennett, D. L., \& George, R. J. (1995). Using the EM38 to measure the effect of soil salinity on Eucalyptus globulus in southwestern Australia. Agricultural Water Management, 27(1), 69-85.

Bennett, M. D. (1987). Variation in genomic form in plants and its ecological implications. Supplement S1. New Phytologist, 106, 177-200.

Betts, H. S., \& Smith, C. S. (1910). Utilization of California eucalypts. United States Department of Agriculture. Forest Service. Circular 179. Washington, the District of Columbia: Government Printing Office.

Bowman, W. D., \& Roberts, S. W. (1985a). Seasonal changes in tissue elasticity in chaparral shrubs. Plant Physiology, 65, 233-236.

Bowman, W. D., \& Roberts, S. W. (1985b). Seasonal and diurnal water relations adjustments in three evergreen chaparral shrubs. Ecology, 66, 739-742.

Boyd, D. (2000). Eucalyptus globulus Labill. In C. C. Bossard, J. M. Randall, \& M. C. Hoshovsky (Eds.), Invasive plants of California's wildlands (pp. 183-187). Berkeley: University of California Press.

Bradstock, R. A. (2008). Effects of large fires on biodiversity in south-eastern Australia: disaster or template for diversity? International Journal of Wildland Fire, 17, 809822.

Burrows, G. E. (2002). Epicormic strand structure in Angophora, Eucalyptus and Lophostemon (Myrtaceae)-implications for fire resistance and recovery. New Phytologist, 153(1), 111-131.

Cairns, J., \& Bidwell, J. R. (1996). Discontinuities in technological and natural systems caused by exotic species. Biodiversity \& Conservation, 5(9), 1085-1094.

Calflora. (2015). Eucalyptus globulus Labill. Distribution by County. Retrieved from http://www.calflora.org/cgi-bin/county_taxon.cgi?where-calrecnum=3534

California Agriculture. (1996). Californians love and hate Eucalyptus. California Agriculture, 50(3), 6-7. Retrieved from http://californiaagriculture.ucanr.org/landingpage.cfm?article=ca.v050n03p6\&fulltext $=$ yes 
California Department of Food and Agriculture. (2009). Plant Health and Pest Prevention Services. Integrated pest control (IPC)-weed management area program (WMA). Retrieved from http://www.cdfa.ca.gov/plant/ar/ipc_wma.html

California Fruit Grower. (1907, July). Eucalyptus. Water and Forest, 7(2), 2.

California Invasive Plant Council (Cal-IPC). (2015a). Assessment of Tasmanian blue gum (Eucalyptus globulus). Retrieved from http://www.calipc.org/ip/inventory/pdf/Eucalyptus_globulus_PAF_2015March.pdf

California Invasive Plant Council (Cal-IPC). (2015b). Retrieved from http://www.calipc.org/

California State Board of Forestry. (1908). A handbook for Eucalyptus planters. 2nd ed. Sacramento, CA: State Printing.

California Water and Forest Association. (1907, July). The timber supply of the United States. Water and Forest, 7(2), 3.

Callaway, R. M., \& Aschehoug, E. T. (2000). Invasive plant versus their new and old neighbors: a mechanism for exotic invasion. Science, 290, 521-523.

Callaway, R. M., \& Ridenour, W. M. (2004). Novel weapons: invasive success and the evolution of increased competitive ability. Frontiers in Ecology and the Environment, 2(8), 436-443.

Calow, P. (1979). The cost of reproduction-a physiological approach. Biological Reviews, 54(1), 23-40.

Cannon, S. H., Gartner, J. E., Michael, J. A., Bauer, M. A., Stitt, S. C., Knifong, D. L., . . . Roque, Y. M. (2007). Emergency assessment of debris-flow hazards from basins burned by the 2007 Ammo Fire, San Diego County, Southern California: United States Geological Survey Open-File Report 2007-1413. United States Department of the Interior. Retrieved from http://pubs.usgs.gov/of/2007/1413/pdf/OF20071413.pdf

Cappuccino, N., \& Arnason, J. T. (2006). Novel chemistry of invasive exotic plants. Biology Letters, 2(2), 189-193.

Carey, G. (1930). The leaf buds of some woody perennials in the New South Wales flora. Proceedings of the Linnean Society of New South Wales, 55, 708-737.

Carrodus, B. B., \& Blake, T. J. (1970). Studies on the lignotubers of Eucalyptus obliqua L'Heri. New Phytologist, 69(4), 1069-1072.

The Center for Biological Diversity, The Center for Food Safety, The Xerces Society, \& Brower, L. (2014, August). Petition to protect the Monarch butterfly (Danaus 
plexippus plexippus) under the endangered species act. The Center for Biological Diversity. Retrieved from http://www.biologicaldiversity.org/species/invertebrates/pdfs/Monarch_ESA_Petition .pdf

Chen, B., \& Yang, J. (1987). Frost injury of Eucalyptus associated with an unusually cold winter in Yunnan province. In P. H. Li (Ed.), Plant cold hardiness (pp. 361-362). New York, NY: Alan R. Liss.

Cheung, Y. N. S., Tyree, M. T., \& Dainty, J. (1975). Water relations parameters on single leaves obtained in a pressure bomb and some ecological interpretations. Canadian Journal of Botany, 53(13), 1342-1346.

Christensen, P. S. (1971). Stimulation of seedfall in Karri. Australian Forestry, 35(3), $182-190$.

Clarke, K. M., Fisher, B. L., \& LeBuhn, G. (2008). The influence of urban park characteristics on ant communities. Urban Ecosystems, 11(3), 317-334.

Clayton-Greene, K. A. (1983). The tissue water relationships of Callitris columellaris, Eucalyptus melliodora and Eucalyptus microcarpa investigated using the pressurevolume technique. Oecologia, 57(3), 368-373.

Clifford, H. T. (1953). A note on the germination of Eucalyptus seed. Australian Forestry, 17(1), 17-20.

Coates, P. (2007). American perceptions of immigrant and invasive species: strangers on the land. Berkeley: University of California Press.

Cody, M. L. (1966). A general theory of clutch size. Evolution, 20(2), 174-184.

Cohen, S., Miller, K., Duncan, K., Gregorich, E., Groffman, P., Kovacs, P., . . Schimel, D. (2001). North America. In McCarthy, J. J., Canziani, O. F., Leary, N. A., Dokken, D. J., and White, K. S. (Eds.), Climate change 2001: impacts, adaptation, and vulnerability. Contribution of working group II to the third assessment report of the intergovernmental panel on climate change (pp. 735-800). Cambridge, United Kingdom: Cambridge University Press.

Cook, R. (1980). The biology of seeds in the soil. In O. T. Solbrig (Ed.), Demography and evolution in plant populations. Volume 15. Berkeley: University of California Press.

Cremer, K. W. (1962). The effect of fire on eucalypts reserved for seeding. Australian Forestry, 26(2), 129-154.

Cremer, K. W. (1965). Effects of fire on seedshed from Eucalyptus regnans. Australian 
Forestry, 29(4), 252-262.

Cremer, K. W. (1972). Morphology and development of the primary and accessory buds of Eucalyptus regnans. Australian Journal of Botany, 20(2), 175-195.

Crisp, M. D., Burrows, G. E., Cook, L. G., Thornhill, A. H., \& Bowman, D. M. J. S. (2011). Flammable biomes dominated by eucalypts originated at the CretaceousPalaeogene boundary. Nature Communications, 2, 1-8.

Cronk, Q. C. B., \& Fuller, J. L. (1995). Plant invaders: the threat to natural ecosystems. London, United Kingdom: Chapman and Hall.

D'Antonio, C. M., \& Vitousek, P. M. (1992). Biological invasions by exotic grasses, the grass/fire cycle, and global change. Annual Review of Ecology and Systematics, 23, 63-87.

Darwin, C. (1859). On the origin of species by means of natural selection or the preservation of favoured races in the struggle for life. London, United Kingdom: John Murray.

Davidson, J. (1996). Ecological aspects of Eucalyptus plantations. In K. White, J. Ball, \& M. Kashio (Eds.), Proceedings of the regional expert consultation on Eucalyptus volume 1, (pp. 35-72). Bangkok, Thailand: Food and Agriculture Organization of the United Nations.

Davies, K. W., \& Sheley, R. L. (2007). A conceptual framework for preventing the spatial dispersal of invasive plants. Weed Science, 55(2), 178-184.

Dawson, T. E. (1998). Fog in the California redwood forest: ecosystem inputs and use by plants. Oecologia, 117(4), 476-485.

Daymet. (2015). Daily surface weather and climatological summaries. Retrieved from https://daymet.ornl.gov/

del Moral, R., \& Muller, C. H. (1969). Fog drip: A mechanism of toxin transport from Eucalyptus globulus. Bulletin of the Torrey Botanical Club, 96(4), 467-475.

del Moral, R., \& Muller, C. H. (1970). The allelopathic effects of Eucalyptus camaldulensis. American Midland Naturalist, 83(1), 254-282.

DiTomaso, J. M., \& Healy, E. A. (2007). Weeds of California and other western states. Oakland: Regents of the University of California Division of Agriculture and Natural Resources.

Doughty, R. W. (2000). The Eucalyptus. A natural and commercial history of the gum tree. Baltimore, MD: The Johns Hopkins University Press. 
Eldridge, K. G., Davidson, J., Harwood, C. E., \& van Wyk, G. (1993). Eucalypt domestication and breeding. Oxford, United Kingdom: Clarendon Press.

Esser, L. L. (1993). Eucalyptus globulus. United States Department of Agriculture Forest Service. Retrieved from http://www.fs.fed.us/database/feis/plants/tree/eucglo/all.html

European and Mediterranean Plant Protection Organization. (2005). Gonipterus gibberus and Gonipterus scutellatus. Bulletin 35. Retrieved from http://www.eppo.int/QUARANTINE/data_sheets/insects/DS_Gonipterus_spp.pdf

Field, C. B., Mortsch, L. D., Brklacich, M., Forbes, D. L., Kovacs, P., Patz, J. A., . . Scott, M. J. (2007). North America. In M. L. Parry, O. F. Canziani, J. P. Palutikof, P. J. van der Linden, \& C. E. Hanson (Eds.), Climate change 2007: impacts, adaptation and vulnerability. Contribution of working group II to the fourth assessment report of the intergovernmental panel on climate change (pp. 617-652). Cambridge, United Kingdom: Cambridge University Press.

Flinn, M. A., \& Wein, R. W. (1977). Depth of underground plant organs and theoretical survival during fire. Canadian Journal of Botany, 55(19), 2550-2554.

Florence, R. G. (1981). The biology of the eucalypt forests. In J. S. Pate \& A. J. McComb (Eds.), The biology of Australian plants (pp.147-180). Perth, Australia: University of Western Australia Press.

Florence, R. G. (1996). Ecology and silviticulture of Eucalyptus forests. Victoria, Australia: Commonwealth Scientific and Industrial Research Organization.

Food and Agriculture Organization of the United Nations. (1979). Eucalypts for planting. Rome, Italy: Author.

Gadgil, M., \& Bossert, W. H. (1970). Life historical consequences of natural selection. American Naturalist, 104(935), 1-24.

Gill, A. M. (1973). Effects of fire on Australia's native vegetation. In: Annual report (4146). Canberra, Australian Capital Territory, Australia: Commonwealth Scientific and Industrial Research Organization.

Gill, A. M. (1977, August). Plant traits adaptive to fires in Mediterranean land ecosystems. In H. A. Mooney \& C. E. Conrad (Tech. Coords.), Symposium on the environmental consequences of fire and fuel management in Mediterranean ecosystems (pp. 17-26). Palo Alto, CA.

Gill, A. M. (1980). Restoration of bark thickness after fire and mechanical injury in a smooth-barked eucalypt. Australian Forest Research, 10(4), 311-319.

Gill, A. M. (1981). Adaptive responses of Australian vascular plant species to fires. In A. 
M. Gill, R. H. Groves, \& Noble, I. R. (Eds.), Fire and the Australian biota (pp. 243272). Canberra, Australian Capital Territory, Australia: Australian Academy of Science.

Gill, A. M. (1997). Eucalypts and fires: interdependent or independent? In J. E. Williams \& J. C. Z. Woinarski (Eds.), Eucalypt ecology: individuals to ecosystems (pp. 151167). Melbourne, Australia: Cambridge University Press.

Griffiths, J., \& Villablanca, F. (2015). Managing Monarch butterfly overwintering groves: making room among the eucalypts. California Fish and Game, 101(1), 40-50.

Grime, J. P., Hodgson, J. G., \& Hunt, R. (1988). Comparative plant ecology. A functional approach to common British species. London, United Kingdom: Unwin Hyman.

Groenendaal, G. M. (1983, June). Eucalyptus helped solve a timber problem: 1853-1880. In R. B. Standiford \& L. T. Ledig (Tech. Coords.), Proceedings of a workshop on Eucalyptus in California (pp. 2-8). General Technical Report PSW-69. Berkeley, CA. United States Department of Agriculture Forest Service.

Groom, P. K., \& Lamont, B. B. (2011). Regional and local effects on reproductive allocation in epicormic and lignotuberous populations of Banksia menziesii. Plant Ecology, 212(12), 2003-2011.

Groom, P. K. \& Lamont, B. B. (2015). Plant life of Southwestern Australia-adaptations for survival. Warsaw, Poland: De Gruyter Open.

Gubler, W. D., \& Koike, S. T. (2014). Pest Notes: Powdery Mildew on Ornamentals. University of California Agriculture \& Natural Resources Publication 7493. Davis: University of California Statewide Integrated Pest Management Program (UCIPM). Retrieved from http://www.ipm.ucdavis.edu/PMG/PESTNOTES/pn7493.html

Hall, N., Johnston, R. D., \& Chippendale, G. M. (1970). Forest trees of Australia. Canberra, Australian Capital Territory, Australia: Australian Government Publishing Service.

Hall, W. (1907). The waning hardwood supply and the Appalachian forests. United States Department of Agriculture. Forest Service Circular 116. Washington, the District of Columbia: Government Printing Office.

Hanes, T. L. (1965). Ecological studies on two closely related Chaparral shrubs in southern California. Ecological Monographs, 35, 213-235.

Hanes, T. L. (1971). Succession after fire in the Chaparral of southern California. Ecological Monographs, 41(1), 27-52.

Hansen, K. (1997). Eucalyptus specialists "down under" are larger and better equipped than North American species to forage flowering trees. Eucalyptus. A complex 
challenge. Fire management, resource protection, and the legacy of Tasmanian blue gum. Retrieved from

http://www.nps.gov/pore/learn/management/upload/firemanagement_fireeducation_n ewsletter_eucalyptus.pdf

Harper, J. L., \& Ogden, J. (1970). The reproductive strategy of higher plants: I. The concept of strategy with special reference to Senecio vulgaris L. The Journal of Ecology, 681-698.

Hijmans, R. J., Cameron, S. E., Parra, J. L., Jones, P. G., \& Jarvis, A. (2005). Very high resolution interpolated climate surfaces for global land areas. International Journal of Climatology, 25(15), 1965-1978.

Homans, G. (1910). Third biennial report of the state forester. Sacramento, CA: State Printing.

Ingham, N. (1908). Eucalyptus in California. Bulletin No. 196. Sacramento, CA: Superintendent State Printing.

Jack London State Historic Park. (2015). Jack London's Eucalyptus. Retrieved from http://jacklondonpark.com/jack-london-eucalyptus.html

Jacobs, M. R. (1937). Field studies on the gum veins in the eucalypts. Bulletin 20. Canberra, Australian Capital Territory, Australia: Commonwealth Forestry Bureau Australia.

Jacobs, M. R. (1955). Growth habits of the eucalypts. Canberra, Australian Capital Territory, Australia: Forestry and Timber Bureau.

Jacobs, M. R. (1970). The genus Eucalyptus in world forestry. Seattle: University of Washington.

James, S. (1984). Lignotubers and burls-their structure, function and ecological significance in Mediterranean ecosystems. The Botanical Review, 50(3), 225-266.

Jaynes, E. T. (1957). Information theory and statistical mechanics. Physical Review, 106(4), 620-630.

Johnson, E. D. (1926). A comparison of the juvenile and adult leaves of Eucalyptus globulus. The New Phytologist, 25(3), 202-212.

Kabashima, J. N., Paine, T. D., Daane, K. M., \& Dreistadt, S. H. (2014). Pest Notes: Psyllids. University of California Agriculture \& Natural Resources Publication 7423. Retrieved from http://www.ipm.ucdavis.edu/PMG/PESTNOTES/pn7423.html\#ipmpagetop 
Keane, J. J., \& Morrison, M. L. (1990). Comparative use of Eucalyptus versus native vegetation by wildlife on Angel Island State Park, California. Transactions of the Western Section of the Wildlife Society, 26, 44-50.

Keeley, J. E. (published 1981, proceedings December, 1978). Reproductive cycles and fire regimes. In H. A. Mooney, T. M. Bonnicksen, N. L. Christensen, J. E. Lotan, \& W. A. Reiners (Eds.), Proceedings of the symposium on fire regimes and ecosystem properties (pp. 231-277). General Technical Report WO-26. Washington, the District of Columbia: United States Department of Agriculture Forest Service.

Keeley, J. E., Aplet, G. H., Christensen, N. L., Conard, S. C., Johnson, E. A., Omi, P. N., ... Swetnam, T. W. (2009). Ecological foundations for fire management in North American forest and shrubland ecosystems. General Technical Report PNW-GTR779. Portland, OR: United States Department of Agriculture Forest Service.

Keeley, J. E., Pausas, J. G., Rundel, P. W., Bond, W. J., \& Bradstock, R. A. (2011). Fire as an evolutionary pressure shaping plant traits. Trends in plant science, 16(8), 406411.

Keeley, J. E., \& Zedler, P. H. (1978). Reproduction of Chaparral shrubs after fire: a comparison of sprouting and seeding strategies. American Midland Naturalist, 99(1), $142-161$.

Kerr, L. R. (1925). The lignotubers of eucalypt seedlings. Proceedings of the Royal Society of Victoria, 37, 79-97.

Kimball, J. S., Running, S. W., \& Nemani, R. (1997). An improved method for estimating surface humidity from daily minimum temperature. Agricultural and Forest Meteorology, 85(1), 87-98.

Kirkpatrick, J. B. (1975). Natural distribution of Eucalyptus globulus Labill. Australian Geographer, 13(1), 22-35.

Koike, S. T., \& Wilen, C. A. (2014). UC pest management guidelines: floriculture and ornamental nurseries. Rust. University of California Agriculture \& Natural Resources Publication 3392. Davis: University of California Statewide Integrated Pest Management Program (UCIPM). Retrieved from http://www.ipm.ucdavis.edu/PMG/r280101211.html

Krugman, S. L. (1970). Observations recorded 1965-1970. Berkeley, CA: United States Department of Agriculture Forest Service.

Krugman, S. L. (1974). Eucalyptus L'Herit Eucalyptus. In C. S. Schopmeyer (Tech. Coord.), Seeds of woody plants in the United States (pp. 384-392). United States Department of Agriculture Handbook 450. Washington, the District of Columbia: Government Printing Office. 
Ladiges, P. Y., Udovicic, F., \& Nelson, G. (2003). Australian biogeographical connections and the phylogeny of large genera in the plant family Myrtaceae. Journal of Biogeography, 30(7), 989-998.

Laemmlen, F. F. (2014). Pest Notes: Sooty Mold. University of California Agriculture \& Natural Resources Publication 74108. Davis: University of California Statewide Integrated Pest Management Program (UCIPM). Retrieved from http://www.ipm.ucdavis.edu/PMG/PESTNOTES/pn74108.html

Lange, R. T., \& Reynolds, T. (1981). Halo effects on native vegetation. Transactions of the Royal Society of South Australia, 105(4), 213-214.

Lanini, W. T., DiTomaso, J. M., \& Norris, R. F. 2002. Weed biology and ecology. In E. A. Kurtz (Ed.), Principles of weed control. 3rd ed. Fresno, CA: Thomson.

Larcher, W. (1995). Physiological plant ecology. Ecophysiology and stress physiology of functional groups. Berlin, Germany: Springer.

Lawson, W., \& The Shiplovers Society of Tasmania. (1949). Blue gum clippers and whale ships of Tasmania. Melbourne, Australia: Georgian House.

Levitt, J. (1980). Responses of plants to environmental stresses. Vol. 1. Chilling, freezing and high temperature stresses. 2nd ed. New York, NY: Academic Press.

Liedloff, A. C., \& Cook, G. D. (2007). Modelling the effects of rainfall variability and fire on tree populations in an Australian tropical savanna with the FLAMES simulation model. Ecological Modelling, 201(3-4), 269-282.

Loreto, F., \& Delfine, S. (2000). Emission of isoprene salt-stressed Eucalyptus globulus leaves. Plant physiology, 123(4), 1605-1610.

Lovett Doust, J. (1980). A comparative study of life history and resource allocation in selected Umbelliferae. Biological Journal of the Linnean Society, 13(2), 139-154.

Maccleery, D. (2008). Re-inventing the United States Forest Service: evolution from custodial management, to production forestry, to ecosystem management. In P. Durst, C. Brown, J. Broadhead, R. Suzuki, R. Leslie, \& A. Inoguchi, (Eds.), Re-inventing forestry agencies: experiences of institutional restructuring in Asia and the Pacific (pp. 30-52). Bangkok, Thailand: Food and Agriculture Organization of the United Nations Regional Office for Asia and the Pacific.

Manifold. (2015). The world's best GIS. Retrieved from http://www.manifold.net/

Maranon, T., \& Grubb, P. J. (1993). Physiological basis and ecological significance of the seed size and relative growth rate relationship in Mediterranean annuals.

Functional Ecology, 7(5), 591- 599. 
Marcar, N. E. (1993). Waterlogging modifies growth, water use and ion concentrations in seedlings of salt-treated Eucalyptus camaldulensis, E. tereticornis, E. robusta and E. globulus. Australian Journal of Plant Physiology, 20(1), 1-13.

Marcar, N. E., \& Termaat, A. (1990). Effects of root-zone solutes on Eucalyptus camaldulensis and Eucalyptus bicostata seedlings: responses to $\mathrm{Na}^{+}, \mathrm{Mg}^{2+}$ and $\mathrm{Cl}^{-}$. Plant and Soil, 125(2), 245-254.

Margolin, L. (1910). Yield from Eucalyptus Plantations in California. California State Board of Forestry Bulletin No. 1. Sacramento, CA: Superintendent State Printing.

Marks, G. C., Kassaby, F. Y., \& Fagg, P. C. (1973). Die-back tolerance in eucalypt species in relation to fertilization and soil populations of Phytophthora cinnamomi. Australian Journal of Botany, 21(1), 53-65.

May, F. E., \& Ash, J. E. (1990). An assessment of the allelopathic potential of Eucalyptus. Australian Journal of Botany, 38(3), 245-254.

McBride, J. R., Sugihara, N., \& Amme, D. (1988). The effects of Eucalyptus establishment on native plant communities. In Focused environmental study: restoration of Angel Island natural areas affected by Eucalyptus (pp. 43-47). Sacramento, CA: California Department of Parks and Recreation.

McClintock, E. (1993). Myrtaceae. In J. C. Hickman (Ed.), The jepson manual: higher plants of California (pp. 766-768). Berkeley: University of California Press.

McCutchan, M. H. (1979). Determining the diurnal variation of surface temperature in mountainous terrain. Journal of Applied Meteorology, 18, 1224-1229.

Melkonian, J. J., Wolfe, J., \& Steponkus, P. L. (1982). Determination of the volumetric modulus of elasticity of wheat leaves by pressure-volume relations and the effect of drought conditioning. Crop Science, 22(1), 116-123.

Metcalf, W. (1968). Introduced trees of central California. Berkeley: University of California Press.

Monaghan, J. (1966). Australians and the gold rush: California and down under 18491854. Berkeley: University of California Press.

Moreshet, S. (1981). Physiological activity, in a semiarid environment, of Eucalyptus camaldulensis Dehn. from two provenances. Australian Journal of Botany, 29(1), $97-$ 110.

Mullin, B. H., Anderson, L. W. J., DiTomaso, J. M., Eplee, R. E., \& Getsinger, K. D. (2000). Invasive plant species. Issue Paper 13. Ames, IA: Council for Agricultural Science and Technology. 
Murray, F. W. (1967). On the computation of saturation vapor pressure. Journal of Applied Meteorology, 6, 203-204.

Myers, B. A., \& Neales, T. F. (1986). Osmotic adjustment, induced by drought in seedlings of three Eucalyptus species. Australian Journal of Plant Physiology, 13(5), 597-603.

National Assessment Synthesis Team (NAST). (2001). Climate change impacts on the United States. The potential consequences of climate variability and change. Cambridge, United Kingdom: Cambridge University Press.

National Invasive Species Council (NISC). (2001). Meeting the invasive species challenge: national invasive species management plan. Washington, the District of Columbia: Author.

National Oceanic Atmospheric Administration. (2015). Weather. Retrieved from http://www.noaa.gov/wx.html

National Park Service. (2006). Eucalyptus. A complex challenge. Fire management, resource protection, and the legacy of Tasmanian blue gum. Retrieved from http://www.nps.gov/pore/learn/management/loader.cfm?csModule=security/getfile \& PageID $=147045$

Neumann, F. G., \& Marks, G. C. (1976). A synopsis of important pests and diseases in Australian forests and forest nurseries. Australian Forestry, 39(2), 83-102.

New Zealand Farm Forestry Association. (2015). Blue-gum psyllid Ctenarytaina eucalypti. Retrieved from http://www.nzffa.org.nz/farm-forestry-model/theessentials/forest-health-pests-and-diseases/Pests/Ctenarytaina-eucalypti/

Nicolle, D. (2006). A classification and census of regenerative strategies in the eucalypts (Angophora, Corymbia and Eucalyptus-Myrtaceae), with special reference to the obligate seeders. Australian Journal of Botany, 54(4), 391-407.

Nilsen, E., \& Orcutt, D. (1996). The physiology of plants under stress. Abiotic factors. New York, NY: John Wiley \& Sons.

Oberlander, G. T. (1956). Summer fog precipitation on the San Francisco peninsula. Ecology, 37(4), 851-852.

O'Dowd, D. J., \& Gill, A. M. (1984). Predator satiation and site alteration following fire: mass reproduction of Alpine Ash (Eucalyptus delegatensis) in southeastern Australia. Ecology, 65(4), 1052-1066.

Paine, T. D., Dreistadt, S. H., \& Millar, J. G. (2014). Eucalyptus longhorned borers. Davis: University of California Statewide Integrated Pest Management Program 
(UCIPM). Retrieved from

http://www.ipm.ucdavis.edu/PMG/PESTNOTES/pn7425.html

Pacific Rural Press. (1877, September 22). The Eucalyptus around the orchard.

California Digital Newspaper Collection. Retrieved from http://cdnc.ucr.edu/cgibin/cdnc?a=d\&d=PRP18770922.2.7.2

Pacific Rural Press. (1879, April 19). Agricultural notes. California. California Digital Newspaper Collection. Retrieved from http://cdnc.ucr.edu/cgibin/cdnc?a=d\&d=PRP18790419\&e=-------en--20--1--txt-txIN------

Pacific Rural Press. (1881, April 9). The Dieback in Cypress and Eucalyptus. California Digital Newspaper Collection. Retrieved from http://cdnc.ucr.edu/cgibin/cdnc?a=d\&d=PRP18810409.2.27.1\&srpos=\&e=-------en-Logical-50--1-byDA--jas.+patrick+tobacco----1864-

Pacific Rural Press. (1883, September 29). The thirsty Eucalyptus. California Digital Newspaper Collection. Retrieved from http://cdnc.ucr.edu/cgibin/cdnc?a=d\&d=PRP18830929.2.4\&e=-------en--20--1--txt-txIN------

Pacific Rural Press. (1888, April 28). Do not set gum trees around your orchard. California Digital Newspaper Collection, p. 373. Retrieved from http://cdnc.ucr.edu/cgi-bin/cdnc?a=d\&d=PRP18880428.2.9.8\&e=-------en--20--1-txt-txIN------

Packham, D. R. (1971). Heat transfer above a small ground fire. Australian Forest Research, 5(1), 19-24.

Parker, J. (1963). Cold resistance in woody plants. The Botanical Review, 29(2), 123-201.

Penfold, A. R, \& Willis, J. L. (1961). The eucalypts. Botany, cultivation, chemistry, and utilization. London, United Kingdom: Leonard Hill Books.

Pereira, J. S., \& Chaves, M. M. (1993). Plant water deficits in Mediterranean ecosystems. In J. A. C Smith \& H. Griffiths (Eds.), Water deficits: plant responses from cell to community (pp. 237-251). Oxford, United Kingdom: Bios Scientific.

Pheloung, P. C. (1995). Determining the weed potential of new plant introductions to Australia. A report on the development of a weed risk assessment system commissioned and endorsed by the Australian weeds committee and the plant industries committee. Perth, Australia: Agriculture Protection Board.

Phillips, S. J. (2005). A brief tutorial on Maxent. Retrieved from http://www.cs.princeton.edu/ schapire/maxent/tutorial/tutorial.doc

Phillips, S. J., Anderson, R. P., \& Schapire, R. E. (2006). Maximum entropy modeling of 
species geographic distributions. Ecological modelling, 190(3-4), 231-259.

Phillips, S. J., \& Dudík, M. (2008). Modeling of species distributions with Maxent: new extensions and a comprehensive evaluation. Ecography, 31(2), 161-175.

Phillips, S. J., Dudík, M., \& Schapire, R. E. (2004). A maximum entropy approach to species distribution modeling. In C. E. Brodley (Ed.), Proceedings of the twenty-first international conference on machine learning (pp. 655-662). Banff, Canada: ACM Press.

Pimentel, D., Lach, L., Zuniga, R., \& Morrison, D. (2000). Environmental and economic costs of nonindigenous species in the United States. BioScience, 50(1), 53-65.

Poole, D. K., \& Miller, P. C. (1975). Water relations of selected species of Chaparral and Coastal Sage communities. Ecology, 56(5), 1118-1128.

Priestley, C. H. B. (1959). Heat conduction and temperature profiles in air and soil. The Journal of the Australian Institute of Agricultural Science, 25(2), 94-107.

Pryor, L. D. (1976). Biology of eucalypts. London, United Kingdom: Edward Arnold.

Purdy, F. W. (1968). Eucalyptus cultivation in California (Unpublished master's thesis). Sacramento State University, Sacramento, CA.

Radosevich, S. R., Holt, J. S., \& Ghersa, C. (1997). Weed ecology. Implications for management. 2nd edition. New York: John Wiley \& Sons.

Randall, J. M., \& Hoshovsky, M. C. (2000). California's wildland invasive plants. In C. Bossard, J. M. Randall, \& M. C. Hoshovsky (Eds.), Invasive plants of California's wildlands (pp. 11-19). Berkeley: University of California Press.

Randall, J. M., Rejmánek, M., \& Hunter, J. C. (1998). Characteristics of the exotic flora of California. Fremontia, 26(4), 3-12.

Recher, H. F. (1991). The conservation and management of eucalypt forests birds: resource requirements for nesting and foraging. In D. Lunney (Ed.), Conservation of Australia's forest fauna (pp. 25-34). Mosman, Australia: Royal Zoological Society of New South Wales.

Reichard, S. H., \& Campbell, F. (1996). Invited but unwanted: A new decision-making process could help curb the devastating effects of invasive plants on natural environments in the U. S. American Nurseryman, 184(1), 39-45.

Reichard, S. H. (1997). Prevention of invasive plant introductions on national and local levels. In J. O. Luken \& J. W. Thieret (Eds.), Assessment and management of plant invasions (pp. 215-227). New York, NY: Springer. 
Reichard, S. H., \& Hamilton C. W. (1997). Predicting invasions of woody plants introduced into North America. Conservation Biology, 11(1), 193-203.

Reid, J. R. W. (1999). Threatened and declining birds in the New South Wales sheepwheat belt: II. Landscape relationships - modelling bird atlas data against vegetation cover. Consultancy report to New South Wales national parks and wildlife service. Canberra, Australian Capital Territory, Australia: Commonwealth Scientific and Industrial Research Organization.

Rejmánek, M. (1995). What makes a species invasive? In P. Pysek, K. Prach, M. Rejmánek, \& P. M. Wade (Eds.), Plant invasions: general aspects and special problems (pp. 3-13). The Hague, Netherlands: SPB Academic.

Rejmánek, M. (1996). A theory of seed plant invasiveness: The first sketch. Biological Conservation, 78(1-2), 171-181.

Rejmánek, M. (2000). Invasive plants: approaches and predictions. Austral Ecology, 25(5), 497-506.

Rejmánek, M. (2001). What tools do we have to detect invasive plant species? In R. H. Groves, F. D. Panetta, \& J. G. Virtue (Eds.), Weed risk assessment (pp. 3-9). Collingwood, Australia: Commonwealth Scientific and Industrial Research Organization.

Rejmánek, M., \& Richardson, D. M. (1996). What attributes make some plant species more invasive? Ecology, 77(6), 1655-1661.

Rejmánek, M., \& Richardson, D. M. (2011). Eucalypts. In M. Rejmánek \& D. Simberloff, (Eds.), Encyclopedia of biological invasions (pp. 203-209). Berkeley: University of California Press.

Rice, C. (n.d.). The science behind Eucalyptus fire hazards. Retrieved from http://claremontcanyon.org/bibliography/eucalyptus_fire_hazard_carol_rice.pdf

Ritter, M. (2011). Eucalyptus terminology and biology. Retrieved from http://www.baobabbotanical.com/Baobab/Eucalyptus_files/Eucalyptus\%20Terminolo gy.pdf

Ritter, M. (2012). Eucalyptus identification workshop. Retrieved from http://www.baobabbotanical.com/Baobab/Eucalyptus_files/Eucalyptus\%20in\%20Cali fornia.pdf

Ritter, M., \& Yost, J. (2009). Diversity, reproduction, and potential for invasiveness of Eucalyptus in California. Madroño, 56(3), 155-167.

Ritter, M., \& Yost, J. (2012, January). Blue gum weediness in California is not 
genetically based. California Native Plant Society conference.

Robichaux, R. H., Holsinger, K. E., \& Morse, S. R. (1986). Turgor maintenance in Hawaiian Dubautia species: the role of variation in tissue osmotic and elastic properties. In T.J. Givnish (Ed.), On the economy of plant form and function (pp. 353380). Cambridge, United Kingdom: Cambridge University Press.

Rogers, M. (2015). Endangered flora of California. First edition. n.p.: n.p.

Rydin, H., \& Borgegard, S. (1991). Plant characteristics over a century of primary succession on islands: Lake Hjalmaren. Ecology, 72(3), 1089-1101.

Sala, O. E., Chapin, F. S., Armesto, J. J., Berlow, E., Bloomfield, J., Dirzo, R., . . Wall, D. H. (2000). Global biodiversity scenarios for the year 2100. Science, 287(5459), 1770-1774.

Santos, R. L. (1997). The Eucalyptus of California. Seeds of good or seeds of evil? Denair, CA: Alley-Cass.

Sax, D. F. (2002). Equal diversity in disparate species assemblages: a comparison of native and exotic woodlands in California. Global Ecology and Biogeography, 11(1), 49-57.

Schofield, N. J., Loh, I. C., Scott, P. R., Bartle, J. R., Ritson, P., Bell, R. W., . . Moore, R. (1989). Vegetation strategies to reduce stream salinities of water resource catchments in south-west western Australia. Report WS 33. Leederville, Australia: Water Authority of Western Australia.

Sellers, C. H. (1910). Eucalyptus: its history, growth, and utilization. Sacramento, CA: AJ Johnston.

Shannon, C. E. (1948). A mathematical theory of communication. The Bell System Technical Journal, 27, 379-423, 623-656. Retrieved from http://lanethames.com/dataStore/ECE/InfoTheory/shannon.pdf

Sheridan, G. J., Lane, P. N. J., \& Noske, P. J. (2007). Quantification of hillslope runoff and erosion processes before and after wildfire in a wet Eucalyptus forest. Journal of Hydrology, 343(1-2), 12-28.

Skolmen, R. G. (1983). Growth and yield of some eucalypts of interest to California. In R. B. Standiford \& F. T. Ledig (Tech. Coords.), Proceedings of a workshop on Eucalyptus in California (pp. 49-57). General Technical Report PSW-69. Berkeley, CA: United States Department of Agriculture.

Skolmen, R. G., \& Ledig, F. T. (1990). Eucalyptus globulus Labill. Bluegum Eucalyptus. 
In R. M. Burns \& B. H. Honkala (Tech. Coords.), Silvics of North America: Vol. 2, hardwoods. Agriculture handbook 654 (pp. 299-304). Washington, the District of Columbia: United States Department of Agriculture. Retrieved from http://www.na.fs.fed.us/pubs/silvics_manual/Volume_2/eucalyptus/globulus.htm

Specht, R. L., \& Rayson, P. (1957). Dark Island heath (Ninety-Mile Plain, South Australia). I. Definition of the ecosystem. Australian Journal of Botany, 5, 52-85.

Stallcup, R. (1997). Deadly Eucalyptus. Observer No. 108. Point Reyes Bird Observatory. Retrieved from http://www.prbo.org/OBSERVER/Observer108/Focus108.2.html

Steinmaus, S. (2001). Invasive plant management project. Retrieved from California Polytechnic State University, San Luis Obispo, Biological Sciences Web site: http://works.bepress.com/ssteinma/6/

Steinmaus, S. (2002a). Lecture on Conventional weed management under fire. Personal Collection of Scott Steinmaus, California Polytechnic State University, San Luis Obispo, CA.

Steinmaus, S. (2002b). Predicting plant invasion with modeling. CalEPPC News, 10(1), $5-9$.

Steinmaus, S. (2002c, October). Using climatic models to predict the potential range of invasive plants. Paper presented at the California Exotic Pest Plant Council Symposium, Sacramento, CA.

Steinmaus, S. (2002d). Lecture on Weed biology. Personal Collection of Scott Steinmaus, California Polytechnic State University, San Luis Obispo, Ca.

Steinmaus, S. (2002e). Lecture on Weed characteristics and classifications. Personal Collection of Scott Steinmaus, California Polytechnic State University, San Luis Obispo, Ca.

Steinmaus, S. (2002f). Lecture on Weed ecology and evolution. Personal Collection of Scott Steinmaus, California Polytechnic State University, San Luis Obispo, Ca.

Steinmaus, S. (2007, January). Traits of invasive plants: adaptation and dispersal. Paper presented at the Annual Conference of the California Weed Science Society. San Diego, CA.

Steinmaus, S., Rejmánek, M., Ritter, M., Jasieniuk, M., \& Knight, C. (n.d.). Toward a mechanistic understanding of introduced Eucalyptus invasivity. Manuscript in preparation.

Stolzenburg, W. (2000). America the bountiful. Taking stock of the nation's biological 
diversity. Nature Conservancy, 50(3), 10-23.

Stoneman, G. L. (1994). Ecology and physiology of establishment of eucalypt seedlings from seed: a review. Australian Forestry, 57(1), 11-29.

Sutherst, R. W. (2000). Climate change and invasive species: a conceptual framework. In H. A. Mooney \& R. J. Hobbs (Eds.), Invasive species in a changing world (pp. 211240). Washington, the District of Columbia: Island Press.

Suddjian, D. L. (2004, June). Birds and Eucalyptus on the central California coast: A love-hate relationship. Paper presented at Ecology and Impacts of Blue Gum Eucalyptus in Coastal California, Moss Landing, CA.

Thornton, P. E., Hasenauer, H., \& White, M. A. (2000). Simultaneous estimation of daily solar radiation and humidity from observed temperature and precipitation: an application over complex terrain in Austria. Agricultural and Forest Meteorology, 104(4), 255-271.

Thornton, P. E. \& Running, S. W. (1999). An improved algorithm for estimating incident daily solar radiation from measurements of temperature, humidity, and precipitation. Agricultural and Forest Meteorology, 93(4), 211-228.

Thornton, P. E., Running, S. W., \& White, M. A. (1997). Generating surfaces of daily meteorological variables over large regions of complex terrain. Journal of Hydrology, 190(3-4), 214-251.

Tinus, R., Burr, K., Atzmon, N., \& Riov, J. (2000). Relationship between carbohydrate concentration and root growth potential in coniferous seedlings from three climates during cold hardening and dehardening. Tree Physiology, 20(16), 1097-1104.

Turnbull, J. W., \& Pryor, L. D. (1978). Choice of species and seed source. In W. E. Hillis \& A. G. Brown (Eds.), Eucalypts for wood production (pp. 6-65). Melbourne, AU: Commonwealth Scientific and Industrial Research Organization.

Turner, N. C. (1979). Drought resistance and adaptations to water deficits in crop plants. In H. Mussell \& R. C. Staples (Eds.), Stress physiology in crop plants (pp. 343-372). New York, NY: John Wiley \& Sons.

Turner, N. C. (1986). Crop water deficits: a decade of progress. Advances in agronomy, $39,1-51$.

Tyrell, I. (1999). True gardens of the gods: Californian-Australian environmental reform, 1860-1930. Berkeley: University of California Press.

University of California Statewide Integrated Pest Management Program (UCIPM). (2014a). Eucalyptus snout beetle-Gonipterus scutellatus. Retrieved from 
http://www.ipm.ucdavis.edu/PMG/GARDEN/PLANTS/INVERT/eucalsnbeet.html

University of California Statewide Integrated Pest Management Program (UCIPM). (2014b). Glossary. Retrieved from http://www.ipm.ucdavis.edu/PMG/glossary.html

University of California Statewide Integrated Pest Management Program (UCIPM). (2014c). Pests in gardens and landscapes. Rusts-many species. Retrieved from http://www.ipm.ucdavis.edu/PMG/GARDEN/FLOWERS/DISEASE/rusts.html

University of California Statewide Integrated Pest Management Program (UCIPM). (2015). Powdery mildew. Retrieved from http://www.ipm.ucdavis.edu/QT/powderymildewcard.html

United States Department of Agriculture (USDA) Forest Service. (n.d.). Tannins. Retrieved from http://www.fs.fed.us/wildflowers/ethnobotany/tannins.shtml

United States Department of Agriculture (USDA) National Agroforestry Center. (1994a). Windbreaks. Retrieved from http://nac.unl.edu/windbreaks.htm

United States Department of Agriculture (USDA) National Agroforestry Center. (1994b). Working trees for agriculture. Retrieved from http://nac.unl.edu/documents/workingtrees/brochures/wta.pdf

United States Fish and Wildlife Service. (2012a). Frequently asked question about invasive species. Retrieved from http://www.fws.gov/invasives/faq.html\#q20

United States Fish and Wildlife Service. (2015b). Monarch butterfly. Retrieved from http://www.fws.gov/international/animals/monarch-butterfly.html

United States Geological Survey. (2015). What causes fish kills? Retrieved from http://water.usgs.gov/edu/qa-chemical-fishkills.html

van der Moezel, P. G., Watson, L. E., Pearce-Pinto, G. V. N., \& Bell, D. T. (1988). The response of six Eucalyptus species and Casuarina obesa to the combined effect of salinity and waterlogging. Australian Journal of Plant Physiology, 15(3), 465-474.

Vitousek, P. M. (1986). Biological invasions and ecosystem properties: can species make a difference? In H. A. Mooney \& J. A. Drake (Eds.), Ecology of biological invasions of North America and Hawaii (pp. 163-76). New York, NY: Springer.

Vitousek, P. M., \& Walker, L. R. (1989). Biological invasion by Myrica faya in Hawaii: plant demography, nitrogen fixation, ecosystem effects. Ecological Monographs, 59(3), 247-265.

Vitousek, P. M., Walker, L. R., Whiteaker, L. D., Mueller-Dumbois, D., \& Matson, P. A. 
(1987). Biological invasion by Myrica faya alters ecosystem development in Hawaii. Science, 238(4828), 802-804.

Vivanco, J. M., Bais, H. P., Stermitz, F. R., Thelen, G. C., \& Callaway, R. M. (2004). Biogeographical variation in community response to root allelochemistry: novel weapons and exotic invasion. Ecology Letters, 7(4), 285-292.

Warren, V. L. (1962). The Eucalyptus crusade. Southern California Quarterly, 44(1), 3142.

Wellington, A. B., \& Noble, I. R. (1985a). Post-fire recruitment and mortality in a population of the mallee Eucalyptus incrassata in semi-arid, south-eastern Australia. The Journal of Ecology, 73(2), 645-656.

Wellington, A. B., \& Noble, I. R. (1985b). Seed dynamics and factors limiting recruitment of the mallee Eucalyptus incrassata in semi-arid, south-eastern Australia. The Journal of Ecology, 73(2), 657-666.

Westbrooks, R. G. (1998). Invasive plants: changing the landscape of America (fact book). Washington, the District of Columbia: Federal Interagency Committee for the Management of Noxious and Exotic Weeds.

Westbrooks, R. G., \& Eplee, R. E. (1996). Regulatory exclusion of harmful nonindigenous from the United States by United States Department of Agriculture Animal and Plant Health Inspection Service Plant Protection and Quarantine. Castanea, 61(3), 305-312.

Whisenant, S. G. (1989, April). Changing fire frequencies on Idaho's Snake River Plains: ecological and management implications. Paper presented at the Symposium on Cheatgrass Invasion, Shrub DieOff, and Other Aspects of Shrub Biology and Management, Las Vegas, NV.

White, P. S. (1997). A bill falls due: botanical gardens and the exotic species problem. The public garden: the journal of the American association of botanical gardens and arboreta, 12(2), 22-25.

White, P. S., \& Schwarz, A. E. (1998). Where do we go from here? The challenges of risk assessment for invasive plants. Weed Technology, 12(4), 744-751.

Wilcove, D. S., Rothstein, D., Dubow, J., Phillips, A., \& Losos, E. (1998). Quantifying threats to imperiled species in the United States. BioScience, 48(8), 607-615.

Wiley, E. O., McNyset, K. M., Peterson, A. T., Robins, C. R., \& Stewart, A. M. (2003). Niche modeling perspective on geographic range predictions in the marine environment using a machine-learning algorithm. Oceanography, 16(3), 120-127. 
Williams, G. W. (2005). The USDA forest service: the first century. Washington, DC: United States Department of Agriculture Forest Service.

Williams, T. (2002). America's largest weed. Audobon, 104(1), 24-31. Retrieved from http://www.scottchurchdirect.com/docs_ted/americas-largest-weed.pdf

Williamson, M. H., \& Fitter, A. (1996). The characters of successful invaders. Biological Conservation, 78(1-2), 163-170.

Wilson, E. O. (1992). The diversity of life. Cambridge, MA: Harvard University Press.

Worldclim. (2015). Global climate data. Bioclim. Retrieved from http://www.worldclim.org/bioclim 


\section{APPENDICES}

Appendix A: Specific thresholds, fractional predicted areas, and omission rates with Pvalues

Table A1 shows common thresholds and corresponding omission rates. Maxent automatically calculates the prediction's statistical significance using a binomial omission test. Binomial probabilities are calculated using $10 \%$ of the data. Otherwise, Maxent uses a normal binomial approximation. These are 1-sided p-values for the null hypothesis that predicted test points are no better than random (with the same predicted area) (Phillips, 2005).

\begin{tabular}{|c|c|c|c|c|c|c|}
\hline Cumulative threshold & Logistic threshold & Description & Fractional predicted area & Training omission rate & Test omission rate & P-value \\
\hline 1.000 & 0.008 & Fixed cumulative value 1 & 0.314 & 0.000 & 0.000 & $9.33 \mathrm{E}-5$ \\
\hline 5.000 & 0.047 & Fixed cumulative value 5 & 0.154 & 0.000 & 0.125 & $1.403 \mathrm{E}-5$ \\
\hline 10.000 & 0.102 & Fixed cumulative value 10 & 0.096 & 0.028 & 0.125 & $5.586 \mathrm{E}-7$ \\
\hline 6.338 & 0.063 & Minimum training presence & 0.133 & 0.000 & 0.125 & $5.312 \mathrm{E}-6$ \\
\hline 16.970 & 0.206 & 10 percentile training presence & 0.060 & 0.097 & 0.125 & 2.172E-8 \\
\hline 13.443 & 0.149 & Equal training sensitivity and specificity & 0.075 & 0.069 & 0.125 & 9.705E-8 \\
\hline 10.660 & 0.111 & Maximum training sensitivity plus specificity & 0.091 & 0.028 & 0.125 & $3.892 \mathrm{E}-7$ \\
\hline 7.021 & 0.069 & Equal test sensitivity and specificity & 0.125 & 0.014 & 0.125 & $3.397 \mathrm{E}-6$ \\
\hline 3.939 & 0.037 & Maximum test sensitivity plus specificity & 0.175 & 0.000 & 0.000 & 8.877E-7 \\
\hline 3.702 & 0.034 & Balance training omission, predicted area and threshold value & 0.181 & 0.000 & 0.000 & $1.147 \mathrm{E}-6$ \\
\hline 11.158 & 0.118 & Equate entropy of thresholded and non-thresholded distributions & 0.088 & 0.056 & 0.125 & 3.018E-7 \\
\hline
\end{tabular}

Table A1. Thresholds and omission rates. 
Appendix B: Marginal response curves
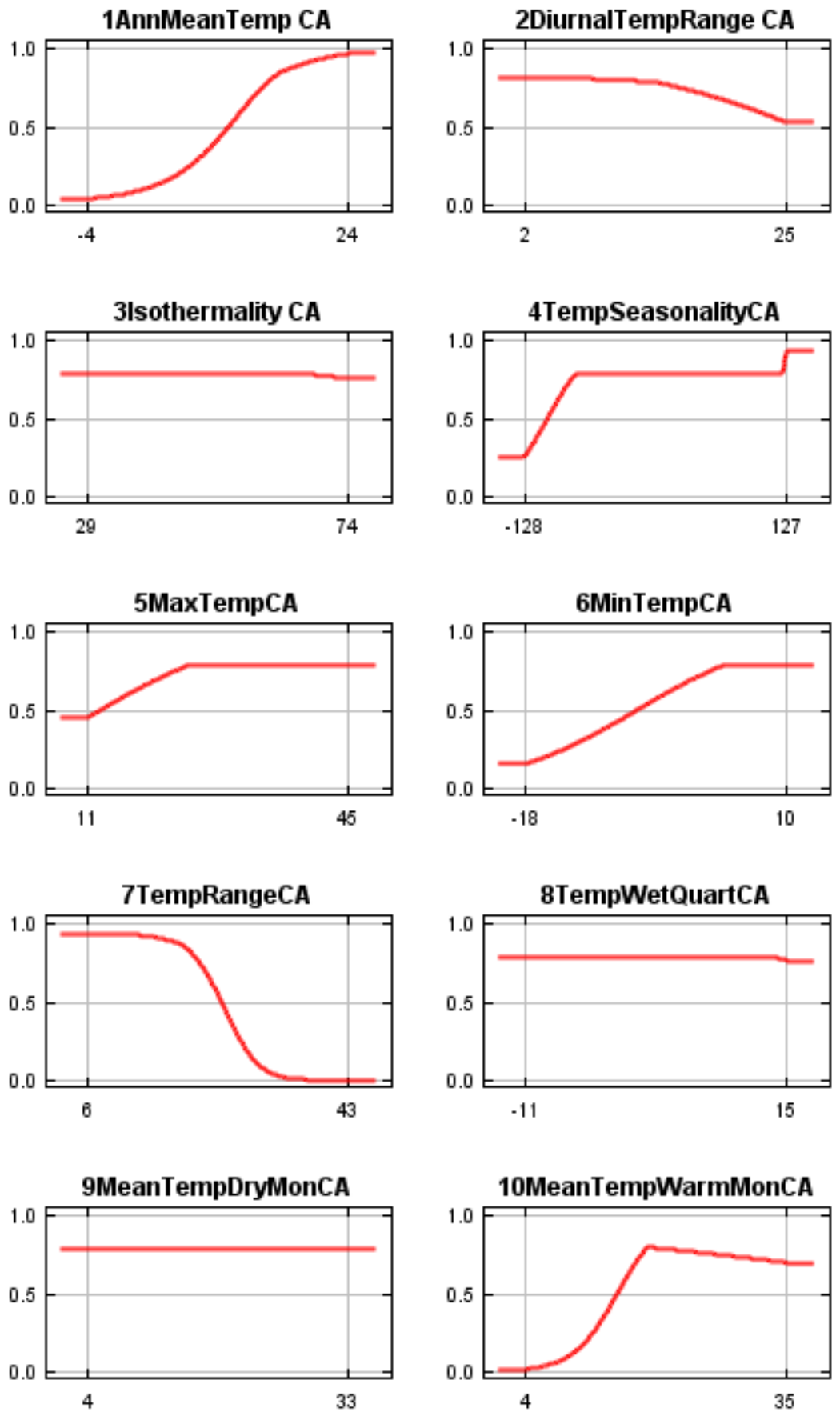
11MeanTempColdMonCA

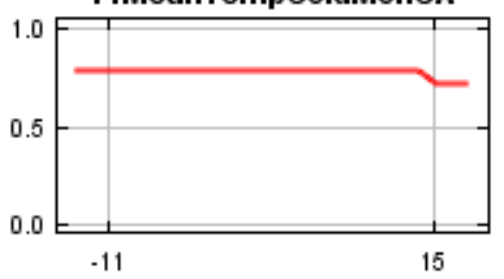

13PrecipWetMonCA

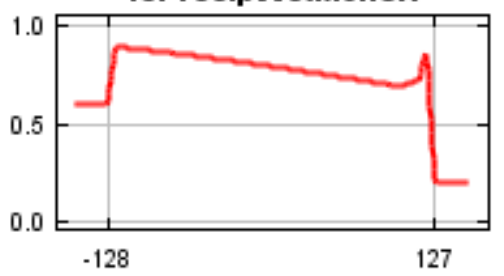

15PrecipSeasonalitycVCA

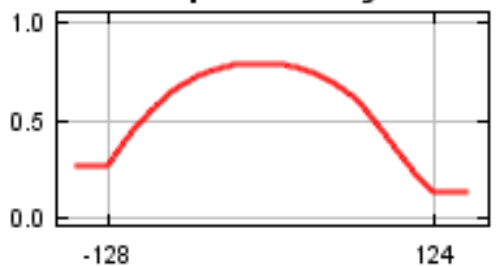

17PrecipDryQuartCA

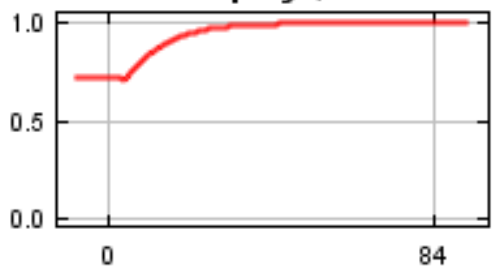

12AnnPrecipCA

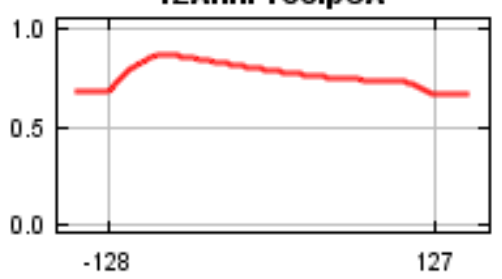

14PrecipDryMonthCA

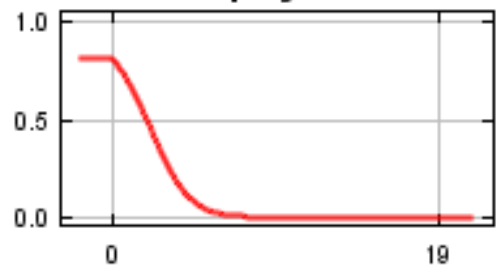

16PrecipWetQuartCA

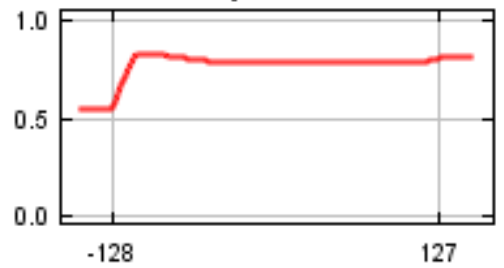

18PrecipWarmQuartcA

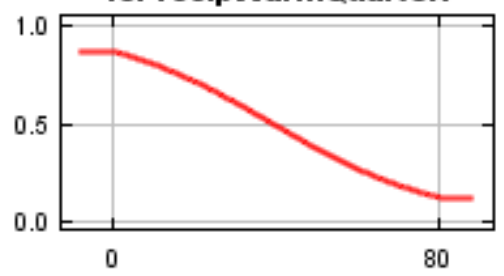

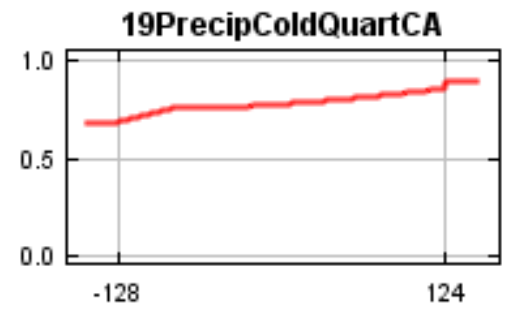

Figure B1. Response curves. These curves display the marginal effect of changing one environmental variable, keeping all other variables at average sample value. 